UNIVERSIDADE DO VALE DO RIO DOS SINOS - UNISINOS UNIDADE ACADÊMICA DE PESQUISA E PÓS-GRADUAÇÃO PROGRAMA DE PÓS-GRADUAÇÃO EM EDUCAÇÃO NÍVEL DOUTORADO

MARIA JANINE DALPIAZ RESCHKE

COERÊNCIA E CONTRADIÇÃO: O CONTEÚDO E A FORMA NO EXERCÍCIO DA DOCÊNCIA DE DIDÁTICA NOS CURSOS DE LICENCIATURA 


\section{COERÊNCIA E CONTRADIÇÃO: O CONTEÚDO E A FORMA NO EXERCÍCIO DA DOCÊNCIA DE DIDÁTICA NOS CURSOS DE LICENCIATURA}

Tese apresentada como requisito parcial para a obtenção do título de Doutora, pelo Programa de Pós-Graduação em Educação da Universidade do Vale do Rio dos Sinos Unisinos.

Área de concentração: Educação

Orientadora: Profa. Dra. Maria Isabel da Cunha 
Dados Internacionais de Catalogação na Publicação (CIP)

R431c Reschke, Maria Janine Dalpiaz

Coerência e contradição : o conteúdo e a forma no exercício da docência de didática nos cursos de licenciatura / Maria Janine Dalpiaz Reschke ; [orientado por] Maria Isabel da Cunha. - São Leopoldo, 2014. 127 ,f. : il.

Tese (Doutorado em Educação). - Universidade do Vale do Rio dos Sinos, 2014.

1. Formação de Professores. 2. Prática Pedagógica. 3. Didática. I. Cunha, Maria Isabel da. II. Título

CDU 371.13

37.02

Bibliotecária Responsável: Ivana Leal de Oliveira - CRB 10/1226 


\title{
COERÊNCIA E CONTRADIÇÃO: O CONTEÚDO E A FORMA NO EXERCÍCIO DA DOCÊNCIA DE DIDÁTICA NOS CURSOS DE LICENCIATURA
}

\begin{abstract}
Tese apresentada como requisito parcial para a obtenção do título de Doutora, pelo Programa de Pós-Graduação em Educação da Universidade do Vale do Rio dos Sinos Unisinos.
\end{abstract}

Área de concentração: Educação

Aprovada em 26 de fevereiro de 2014.

BANCA EXAMINADORA

Profa. Dra. Maria Isabel da Cunha - Unisinos (Orientadora)

Profa. Dra. Dóris Pires Vargas Bolzan - UFSM

Profa. Dra. Maria Antonia Ramos de Azevedo - Unesp/Rio Claro

Profa. Dra. Mari Margarete dos Santos Forster - Unisinos

Profa. Dra. Marly Therezinha Mallmann - Unisinos 
A Paulo e Pauline, que compartilharam a expectativa de ingressar no doutorado e conviveram com as minhas angústias e descobertas. Estiveram ao meu lado durante esta caminhada, me apoiando e acreditando na construção desta tese. Parceiros e incentivadores. Obrigada pelo carinho! 


\section{AGRADECIMENTOS}

Esta tese é produto de esforços e tempos compartilhados, na vida acadêmica e na vida cotidiana. As inquietações em torno da docência universitária me acompanham durante boa parte da minha existência em diversos cenários que têm sido espaços de prática e reflexão.

Muito tempo, muitas aprendizagens, muitas pessoas e instituições às quais quero expressar o meu reconhecimento.

Agradeço a Deus por ter me propiciado todas essas vivências, que me possibilitaram crescer como pessoa e profissional.

Aos meus pais, leda e Lério, por terem acreditado e investido em mim, que me ensinaram o valor do trabalho, da honestidade e o respeito pelo outro. Aos meus irmãos, Roni e Milene, por terem dividido muitas aventuras e descobertas durante as nossas vidas. Às minhas tias Zélia (in memoriam) e Zilda por terem me mostrado desde pequena o que é ser professora. Às minhas queridas comadres Ana e Heloisa (in memoriam), com quem convivi e aprendi na minha primeira experiência no ensino superior.

Agradeço à professora Mabel, que acolheu com abertura ser parceira na composição desta tese, respeitando meu ritmo, ajustando nossos passos intelectuais de maneira competente, comprometida, respeitosa e afetiva. Sempre com o carinho e elegância que Ihes são pertinentes. Um exemplo!

Aos meus colegas do grupo de pesquisa Formação de Professores, Ensino e Avaliação, que estiveram juntos em muitos momentos, incentivando e contribuindo.

Aos professores e estudantes, atores desta pesquisa, pelo interesse e pela motivação em contribuir, aceitando apresentar as suas trajetórias profissionais e as suas aulas, condições indispensáveis para a produção desta tese. É deles a contribuição mais significativa.

Aos meus companheiros de caminhada cotidiana na instituição em que atuo, que estiveram juntos no processo de ensinar na universidade: Elza, Maria de Fátima, Aline, Joice e Marione.

Às colegas de percurso no doutorado, em especial, Inajara e Valeska, que embaixo da figueira, juntas fazendo sol ou chuva, espirituosas, alegres e especiais, souberam ouvir e me ajudaram a transpor os obstáculos que dia a dia eram colocados no meu caminho. Todos os meus colegas de turma me ensinaram algo, 
serei sempre grata. Foi um privilégio ter compartilhado as histórias de vida, angústias, descobertas e as risadas com vocês!

Obrigada à banca examinadora, professoras Dóris, Maria Antonia, Mari e Marly pelo aceite e por suas importantes contribuições na qualificação do projeto desta tese, que colaboraram para que ela finalmente tivesse este desenho.

Agradeço também aos professores do PPG, que me acompanharam em parte desse percurso e que contribuíram na minha caminhada. Obrigada às secretárias do PPG, Caroline e Loinir, pelo carinho e pela compreensão, e às bolsistas da professora Mabel, especialmente à Josi e à Camila, pela disponibilidade, pelo carinho e pelo respeito. 


\section{RESUMO}

O estudo teve como objetivo compreender como os docentes das disciplinas de Didática Geral e Didática Específica em cursos de licenciatura constituíram as suas trajetórias e como estas repercutem na sua prática pedagógica e na formação inicial dos seus estudantes. A metodologia foi construída na perspectiva qualitativa, de inspiração etnográfica, com observação direta de situações de aula e entrevistas semiestruturadas com os seis professores, sendo três de Didática - Organização do Trabalho Pedagógico e três de Didática Específica que atuam nos cursos de Pedagogia e Biologia. Envolveu, ainda, 12 estudantes dos respectivos cursos, que realizavam essas disciplinas durante o período da investigação. As entrevistas com os docentes tiveram como foco compreender como estes construíram a sua profissionalidade, a partir da análise das suas trajetórias profissionais. As observações em sala de aula procuraram compreender a articulação da aula dos docentes e as relações que estabeleciam com os estudantes. As entrevistas com os estudantes foram estruturadas para permitir a compreensão de como os docentes das disciplinas de Didática Geral e Específicas articulavam os saberes necessários para o exercício da docência, e a repercussão dos mesmos na formação inicial desses estudantes. A tese reafirma que a docência universitária é feita de rupturas, continuidades e contradições entre o discurso e a prática, e a maioria dos docentes expressou preocupação com a relação entre a forma e o conteúdo das disciplinas que ministrava. O campo pedagógico, atravessado por diferentes valores e crenças, envolve a docência que lida com desafios que a reconfiguram e a ressignificam. É um fenômeno de natureza coletiva e complexo, sendo vivido socialmente, distante de simplificações. Serviram como fundamento teórico para esse estudo as contribuições em Cunha (1989, 1998), Pimenta (1998), Leite (1999), Anastasiou (1998), Balzan (1998), Masetto (1998,2003), Morosini (2003), Pimenta e Anastasiou (2002), Veiga (1994), Castanho e Veiga (2001),Zabalza (2004), Isaia e Bolzan (2009), entre outros.

Palavras-chave: Didática. Licenciaturas. Formação inicial de professores. Trajetórias docentes. Conteúdo e forma. Prática pedagógica. 


\begin{abstract}
The study had the objective to understand how teachers in the disciplines of General Didactics and Specific Didactics in undergraduate courses constituted their trajectories and how these affect their pedagogical practice and the initial training of their students. The methodology was built on qualitative perspective, of ethnographic inspiration, with direct observation of classroom situations and semi-structures interviews with six teachers, three of Didactics - Organization of Pedagogical Work and three of Specific Didactics that act in Pedagogy and Biology courses. It also involved 12 students of these courses, which attended these disciplines during the investigation period. The interviews with teachers were focused on understanding how they build their professionalism, from the analysis of their professional careers. The observations in the classroom sought to understand the articulation of teachers' class and the relations that they established with students. The interviews with students were structured to allow the understating of how teachers in the disciplines of General and Specific Didactics articulated the knowledge necessary for the practice of teaching, and their impact on the initial training of these students. The thesis maintains that university teaching is made of ruptures, continuities and contradictions between discourse and practice, and most teachers expressed concern about the relation between the form and content of the disciplines they ministered. The pedagogical field, crossed by different values and beliefs, involves the teaching that deals with challenges that reconfigure and resignify it. It is a phenomenon of collective and complex nature, lived socially, distant of simplifications. They was used as theoretical statemente to this study the contribuitions in Cunha (1989, 1998), Pimenta (1998), Leite (1999), Anastasiou (1998), Balzan (1998), Masetto (1998,2003), Morosini (2003), Pimenta e Anastasiou (2002), Veiga (1994), Castanho e Veiga (2001),Zabalza (2004), Isaia e Bolzan (2009), entre outros.
\end{abstract}

Keywords: Didactics. Graduation. Initial teacher training. Teachers' trajectories. Content and form. Pedagogical practice. 


\section{LISTA DE ILUSTRAÇÕES}

Quadro 1 - Caracterização dos docentes participantes da pesquisa................. 66

Quadro 2 - Caracterização dos estudantes participantes da pesquisa............. 69

Quadro 3 - Aspectos significativos na prática dos docentes investigados a partir do olhar dos estudantes. 
3 A UNIVERSIDADE: CENÁRIO DA FORMAÇÃO DE PROFESSORES E DA DOCÊNCIA NOS CURSOS DE LICENCIATURA ........................... 22

3.1 A universidade no Brasil: contextos contemporâneos......................... 22

3.2 Docência universitária: entre a tradição e a inovação........................... 31

3.3 A profissionalização em questão.................................................... 37

3.4 O professor universitário e sua formação.............................................. 40

4 A DOCÊNCIA E A APRENDIZAGEM NAS LICENCIATURAS.................. 45

4.1 Os cursos de licenciatura na legislação brasileira ............................... 46

4.2 A docência e a aprendizagem nas licenciaturas................................ 47

5 CAMINHOS PERCORRIDOS: A TRILHA DA PESQUISA ..................... 54

5.1 Um pouco da história da instituição pesquisada ................................. 54

5.2 Procedimentos e questões norteadoras............................................ 56

5.3 Abordagem metodológica: os instrumentos.................................... 58

5.4 Os interlocutores: professores e estudantes.................................... 63

6 PROFESSORES DE DIDÁTICA E SEUS ESTUDANTES: OS ARTÍFICES DA FORMAÇÃO ................................................... 70

6.1 Pensando o vivido através das observações..................................... 71

6.2 As trajetórias dos professores e as suas principais influências........... 76

6.3 A aula: o lócus da relação teoria e prática........................................ 86

6.4 O estudante: protagonista da formação............................................ 98

7 APRENDIZAGENS CONSTRUÍDAS: TECENDO ALGUMAS CONCLUSÕES. 
APÊNDICE A - Termo de Consentimento Livre e Esclarecido (TCLE).. 118 APÊNDICE B - Roteiro de entrevista aos professores das disciplinas de Didática-OTP e Didáticas Específicas... 121

APÊNDICE C - Roteiro de entrevista com os estudantes. 122

ANEXO A - Matriz curricular do curso de Pedagogia. 123

ANEXO B - Matriz curricular do curso de Biologia. 124 


\title{
1 INTRODUÇÃO
}

\begin{abstract}
Refletir sobre a Universidade é, entre outras coisas, um exercício de responsabilidade profissional porque se trata de conhecer melhor onde se trabalha. Uma tomada de consciência do lugar do próprio trabalho é uma possibilidade séria de fazer melhor esse trabalho. Por outro lado, refletir sobre a Universidade implica o reconhecimento da importância do trabalho universitário em si, à margem do sujeito ou das matérias concretas que intervenham em um caso particular. (CALERA, 1990, p. 17).
\end{abstract}

Este estudo se propôs a investigar a prática do docente das matérias pedagógicas nos cursos de Pedagogia e Biologia na sua pluralidade e multiplicidade, procurando reconhecer a sua dinâmica e processualidade. Dessa forma e com o cuidado necessário, favoreceu meu trânsito pela aula universitária e a possibilidade de compreender, além da dimensão epistemológica do processo de ensinar e aprender, também as tramas engendradas nas relações que configuram a dimensão didático-pedagógica.

$O$ interesse pela temática teve origem em meus percursos e minhas inquietações profissionais. Houve, também, o fator que teceu a problemática desta tese, relacionado aos dilemas que os professores universitários vivenciam, motivados pelas políticas de educação voltadas para o ensino superior e as questões internas na instituição investigada. Trata-se de uma universidade privada, na qual o professor é contratado por hora-aula, e a sua carga horária é variável a cada semestre, pois existe uma relação entre o número de alunos matriculados e a oferta de disciplinas. Essa condição, de certo modo, desencadeia uma instabilidade e insegurança funcional que vivencio e compartilho com meus pares, podendo influenciar o fazer pedagógico do professor na sala de aula, entrelaçando-se nas relações acadêmicas entre docentes e discentes, e entre pares.

Diante do desafio de formar professores para atuar no distinto e complexo cenário da educação contemporânea, instala-se a necessidade de pesquisas que tratem da formação pedagógica e do trabalho dos docentes universitários, formadores de futuros professores. Ser um docente formador de novos professores nos estimula a refletir acerca do ambiente da aula na universidade e de como são realizadas as práticas pedagógicas. Compreender como o professor universitário aprende a sua docência e como realiza seu trabalho nos cursos de licenciatura provoca inquietações. 
Com o objetivo de cercar essas relações, busquei pesquisas no campo da Pedagogia Universitária que tratam especificamente sobre a formação e o desenvolvimento dos professores, e que serviram de fundamento para este estudo. Encontrei contribuições em Cunha (1989, 1998), Pimenta (1998), Leite, 1999, Anastasiou (1998), Balzan (1998), Masetto (1998,2003), Morosini (2003), Pimenta e Anastasiou (2002), Pimenta (2000) ,Veiga (1994), Castanho e Veiga (2001),Zabalza (2004), Isaia e Bolzan (2009), entre outros.

Concordo, entretanto, com Morosini (2003), quando afirma que a formação do professor de ensino superior não se constitui ainda em uma área de sólida produção científica, mesmo que venha se consolidando nesses últimos anos.

No Brasil, ao longo da história do ensino superior, diversas iniciativas de
grupos de professores, de instituições do ensino superior e mesmo do
Ministério da Educação (MEC) visando à capacitação do professor
universitário foram assumidas, nem sempre institucionalizadas, portanto, na
dependência da sensibilidade dos dirigentes e, em grande parte, centradas
numa lógica tecnicista. Apesar das fragilidades, essa trajetória contribuiu
para a constituição do campo de estudo e pesquisa, que veio a ser
denominado de pedagogia universitária. (pág.46)

Em um período mais recente, na busca de consolidação deste campo, emergiram eventos científicos realizados sobre essa temática. Como exemplos, podem-se citar: o I Simpósio de Educação Superior, na Ulbra, em Canoas-RS (1999); o I Congresso Ibero-Americano de Formação de Professores, promovido pelo Centro de Educação e PPGE da Universidade Federal de Santa Maria-RS (2000); e o II Simpósio de Educação Superior (Unisinos, 2001), congregando representantes de diversas regiões do país, que deram origem à Rede Sul-Brasileira de Investigadores de Educação Superior (Ries). Dentre os objetivos da Ries, incluem-se: fortalecer projetos e metas comuns, resgatando, partilhando e divulgando experiências significativas na educação superior e promover a interação entre os professores-investigadores, em um contexto colaborativo. Desde então, a rede vem dando intensa colaboração ao campo da Pedagogia Universitária, realizando pesquisas cujos resultados são socializados em eventos e cujos produtos são divulgados em livros e periódicos especializados, assumindo posição de destaque no cenário brasileiro e latino-americano.

Com o objetivo de conhecer a realidade sobre as produções de pesquisa no campo da Pedagogia Universitária, mais precisamente da formação de professores dos cursos de licenciaturas, inicialmente procurei mapear os estudos realizados 
sobre essa temática, com o intuito de explorar diferentes aspectos da formação e as dimensões de análise destacadas e privilegiadas. Tive a intenção de promover aproximações com as pesquisas já realizadas sobre a trajetória do docente de ensino superior, explicitando os principais temas e as propostas metodológicas abordadas, bem como realizar uma leitura criteriosa das pesquisas que se aproximavam do tema que me interessa.

Recorri aos trabalhos apresentados nas reuniões da Associação Nacional de Pesquisa em Educação (Anped), de 2005 a 2010, no GT4 de Didática e GT8 de Formação de Professores, e no Encontro Nacional de Didática e Prática de Ensino (Endipe), de 2008 e 2010. Também foram buscados artigos voltados à formação de professores, entre os quais estão: Cunha (1989, 1999), Sacristán e Peres(1998), Marcelo Garcia (1995), Charlot (2006), Tardif (2002), Leite (2003) e Alarcão e Tavares (2003). Muitas dessas pesquisas serviram de suporte para este trabalho.

$\mathrm{Na}$ construção do estudo, observei que os espaços de investigações sobre a formação de professores do ensino superior estão se ampliando, especialmente nos programas de pós-graduação que investem em estudos nessa direção.

Entretanto a trajetória investigativa continua a propor uma agenda de questões, que merecem aprofundamento. Entre elas, pontuo: em que medida a história de vida dos professores implica oportunidades formativas criadas em aula para que os alunos construam conhecimentos e vivências significativas para a prática pedagógica? Qual o contexto social, econômico e político em que os docentes desta pesquisa estão inseridos? Como o processo de ensinoaprendizagem por eles protagonizado se instaura? Que indícios essa condição apresenta? Como ela está alicerçada na sua formação? Por quais motivos ou crenças investem nesse processo? Esses professores realizaram mestrado ou doutorado em suas áreas específicas ou em educação? Quais estratégias metodológicas utilizadas pelos docentes do ensino superior são consideradas pelos estudantes/docentes como práticas que possibilitam novos saberes? Quais são os conhecimentos e significados que docentes e discentes constroem em aula quando vivenciam as disciplinas de didática? Como se estabelece a relação pedagógica entre docentes e discentes? Quais são os novos saberes e oportunidades que estão sendo incorporados na formação do novo professor? Diante dessa complexidade de questões, agrupá-las-ei em dimensões que serão explicitadas no capítulo 5 , no qual apresento o caminho metodológico. 
Esses questionamentos contribuíram para o delineamento do objeto a ser por mim pesquisado. O intuito foi buscar compreender como se constrói a docência dos professores das disciplinas pedagógicas dos cursos de licenciatura e reconhecer os sentidos e significados que esses docentes atribuem ao seu trabalho pedagógico como formador. Entre as disciplinas pedagógicas, compreendo que a Didática Geral e as Didáticas Específicas são as mais representativas do campo.

Nessa direção, este estudo está organizado a partir da introdução. No segundo capítulo, inicio Construindo o cenário da pesquisa, em que, através da minha trajetória apresentada partir de uma narrativa, procuro cercar o objeto da tese, assim como o processo que ocorreu na definição das inquietações desencadeadas a partir do meu desenvolvimento profissional e do âmbito acadêmico no qual me insiro.

No terceiro capítulo, que denominei $A$ universidade: cenário da formação de professores e da docência nos cursos de licenciatura, procuro trazer algumas reflexões para contribuir com a compreensão dos processos de constituição da universidade e o papel do professor nesse contexto.

A formação docente e as questões implicadas nesta compõem o capítulo 4, intitulado $A$ docência e a aprendizagem nas licenciaturas, na intenção de efetuar uma revisão conceitual para posterior tentativa de articulação entre teoria e empiria.

A proposta metodológica é o motivo do capítulo 5 - Caminhos percorridos: a trilha da pesquisa -, no qual descrevo os caminhos metodológicos da investigação, como foi realizada e elaborada a partir de um estudo qualitativo de inspiração etnográfica. Tendo como referência a questão geral, emergiram os objetivos do estudo, os interlocutores, os procedimentos e os instrumentos de coleta de dados, bem como os procedimentos de análise dos achados.

O sexto capítulo versa sobre a interlocução com os professores de Didática e seus estudantes: os artífices da formação dos cursos pesquisados, assim como suas trajetórias e percepções, tensões e esperanças acerca dos processos de ensino-aprendizagem na aula universitária.

As aprendizagens construídas e inferências sobre o tema pesquisado constam no capítulo 7 , seguido pelas referências bibliográficas e, ao final, pelos apêndices e anexos. 


\section{CONSTRUINDO O CENÁRIO}

Ao procurar na memória o que realmente me levou à escolha do caminho para a docência, emerge a lembrança de que, na infância, desejei ser professora ou investigadora policial. Esses desejos se expressavam pelo brincar. Ora estava investigando o sumiço de alguém ou de alguma coisa e, então, montava com meus primos uma história e saíamos pelas ruas buscando pistas para solucionar o caso. Ora queria ser professora, ministrando aulas a meus alunos, os mesmos queridos primos que me acompanhavam nas investigações policiais, utilizando os cadernos que minhas tias, estudantes do curso Normal deixavam em seus bidês. Eram cadernos coloridos com várias atividades para que meus alunos as realizassem.

Sempre inventava coisas novas. Acreditava que eles adoravam realizá-las. Utilizava como lousa os quadros de divulgação que meu pai tinha a intenção de doar aos comerciantes. Eram pequenos, mas serviam. Eram fáceis de carregar e, com gizes coloridos que sempre conseguia arrecadar ao final das aulas, nas caixas de gizes que os professores lá esqueciam, desenvolvia as minhas aulas.

Vivi minha infância sempre próxima à família, descendentes de italianos. Muitas eram as tias, e a maioria delas era professora. Duas eram comerciantes e essa era a diversidade de profissões na família. Assim fui me constituindo nesse contexto. Incomodava-me com a linearidade e a rotina, pois queria ser diferente. Mas ao mesmo tempo sabia que ser professora me fascinava, mexia comigo.

Iniciei o curso de Sociologia na PUCRS. Foram anos de descobertas. Conheci teorias sociológicas as quais me auxiliaram a compreender melhor a realidade, mas também teorias que mostravam a complexidade do que é viver em sociedade. Apresentei meu trabalho de conclusão em antropologia social, sobre Umbanda, analisando a religiosidade a partir da perspectiva de ser predominantemente dirigida por mulheres, as Mães de Santo. Buscava compreender o papel dessas mulheres na vida dos seus seguidores e saber quem estes eram e por que reconheciam suas lideranças.

Em seguida, cursei uma especialização na Unisinos, em Educação Popular. Foi uma experiência instigante: resolvi fazer, com outros três colegas, um trabalho de campo com meninos de rua que viviam na praça do Colégio Rosário. Realizamos o estudo durante um ano, convivendo com esses meninos quase que diariamente. Foi uma experiência ao mesmo tempo maravilhosa - pela aprendizagem de como 
eles viam a vida, a sociedade, a família e a instituição que serviria para readaptá-los à sociedade - e penosa, por vermos o quanto estamos de mãos amarradas para mudarmos essa situação. Como proposta, nosso grupo encontrou, dentro da Febem, pessoas dispostas a oferecer uma escola aberta a esses meninos, que se denominava Plínio Kroeffe e se localizava no bairro Cidade Baixa, em Porto Alegre. Ficou cada vez mais presente em mim a importância da escola na vida das pessoas, ou seja, compreendi que poderia ser essa uma das formas de, além de analisar a sociedade, transformá-la.

Regressei a Torres e fui trabalhar em uma pequena escola estadual no Passo de Torres, na época um pequeno povoado de pescadores, atravessando uma ponte pênsil de arames suspensos, como sugere o nome. Foi minha primeira experiência no magistério e senti uma forte responsabilidade de mostrar àquelas crianças que existia a possibilidade de outro futuro para elas, diferente daquele que parecia predestinado, pois filhos de pescadores pensam em ser pescadores no futuro. Trabalhei três anos com turmas de quinta a oitava séries.

Em 1992, com a implantação da Universidade Luterana do Brasil em Torres, comecei a trabalhar com as disciplinas de Sociologia Geral I e II e Sociologia da Educação I e II. A primeira era ofertada a todos os cursos e as três últimas ao curso de Pedagogia. Trabalhei durante cinco anos e, para minha satisfação, encontrei na universidade alunos que haviam sido meus no Passo de Torres. Senti-me um pouco responsável por isso. Hoje estão formados (pedagogas, advogados, bacharéis em turismo e administradores) e trabalhando, alguns em sua cidade de origem, outros em diferentes cidades. Percebi o quanto foi importante o nosso trabalho e o quanto foi possível contribuir para que eles percebessem a realidade e a transformassem, se assim o quisessem.

Nesse mesmo período, eu e uma aluna bolsista realizamos uma pesquisa sobre a formação dos professores de primeiro e segundo graus no município de Torres. Esse contato com a educação em diferentes estágios me fez relacioná-la aos meus estudos sociológicos. As inquietações acerca da formação de professores se tornaram mais latentes, pois nesse estudo compreendi que a relação entre universidade e escola estava desarticulada. O curso de Pedagogia era o único de licenciatura. Tínhamos uma demanda reprimida de alunos, pois não havia outras universidades próximas. Os estudantes, em sua maioria, estavam no exercício da 
docência em escolas da região. A universidade desconhecia a realidade da comunidade, da escola e dos alunos.

Por contingências da vida fui morar em Brasília. Lá fiz mestrado em Sociologia, na Universidade de Brasília. Acostumada a universidades particulares, deparei-me com outra realidade, com colegas de diversos cursos, estados e contextos. Encontrei também professores que me oportunizaram crescer ainda mais, proporcionando o desafio de compreender a importância da diferenciação institucional e da racionalização das imagens do mundo. Conheci a teoria de Peter Berger e me aprofundei na teoria weberiana, além de rever Durkheim, Marx e conhecer Habermas e Bourdieu. Esses sociólogos me propiciaram compreender com mais clareza a relação entre as instituições sociais, na criação e recriação do mundo da vida, que integram em algum nível a multiplicidade de formas de vida existentes na contemporaneidade.

Retomei meus estudos sobre religião e apresentei minha dissertação sobre as representações sociais da mulher inserida no movimento de renovação carismática (MRC) e as transformações em seu cotidiano. Fiz o trabalho de campo em Torres, pois sentia sempre muito forte o compromisso de voltar a meu lugar de origem e junto com os habitantes locais poder compreender melhor os processos que o mundo da vida desencadeava no cotidiano. Realizei entrevistas com vinte e duas mulheres que pertenciam ao $\mathrm{MRC}^{1}$, de diferentes idades, estados civis e escolaridades. Nos resultados obtidos e analisados, concluí que, mesmo sendo um movimento religioso conservador, propiciava autonomia às mulheres com maior adesão ao movimento. O que mais me chamou a atenção foi que elas acabavam buscando estudar, completar o ensino médio e cursar a universidade, que agora estava próxima fisicamente delas.

Retornei ao RS e retomei meu trabalho na Ulbra, agora em Gravataí, Carazinho e Canoas, nos cursos de Pedagogia e outras licenciaturas. Como voltei a trabalhar com esses cursos, passei a observar que muitos alunos queriam ser professores(as) com uma visão transformadora, assim como aquelas minhas alunas de Torres. Mas no momento em que ficavam frente a frente com a prática se sentiam

\footnotetext{
${ }^{1}$ Movimento de Renovação Carismática: é um movimento da Igreja Católica Apostólica Romana surgido nos Estados Unidos em meados da década de 1960. Este movimento procura oferecer uma abordagem inovadora às formas tradicionais dos ritos e da mística da Igreja. Chegou ao Brasil na década de 1970.
} 
inseguros e tendiam a trabalhar de forma conservadora. Então me perguntei: por que isso ocorre? Percebi que, mesmo as realidades dos alunos sendo bem diferentes (Carazinho, Canoas e Gravataí, cidades diferenciadas não só pelo número de habitantes e pela extensão territorial, mas também pela diversidade cultural, entre outras características), a vontade era a mesma. Mas por que eles não atingiam o objetivo? Tem a ver com o modo como eu ensino? Será o currículo? Os outros professores? Ou quem sabe tudo isso junto? Essas observações e a vivência da realidade de ensino superior em universidade particular me trouxeram várias questões: como formamos esses professores? O que eles pensam de sua formação? Como é constituída sua identidade? Essa proximidade fez emergir diversas inquietações que acabaram por mexer em alguns pontos relevantes da minha vivência, pois a formação de professores sempre me envolveu de maneira especial: seja pela trajetória de me tornar docente universitária, seja pelos desafios que me foram colocados frente ao fazer e pensar o ensino na universidade. Esses caminhos, entre outros motivos e vontades, levaram-me a assumir a formação do professor universitário como um eixo privilegiado de minha prática e de minhas pesquisas.

É a partir desse lugar de formadora de outros professores que procuro discutir a formação do professor universitário. Durante minha trajetória profissional, atuei em dois níveis de ensino, fundamental e superior. Dessa forma, baseando-me na própria prática e refletindo sobre o que dava certo ou não, o que Schön (1995) chama de o "prático reflexivo", fui aprendendo a ser professora. Novamente foi a experiência, mais do que os estudos formais que obtive na universidade, que me deu a necessária sustentação para prosseguir na docência. Vale ressaltar que, na minha formação, os pressupostos tendiam a reduzir a questão da docência à aquisição de técnicas e procedimentos considerados necessários e suficientes ao bom andamento das questões pedagógicas, atendendo à lógica da racionalidade técnica.

À medida que minha docência de ensino superior estava sendo construída e o convívio nesse espaço de trabalho era cada vez mais aprofundado, tive de me haver com múltiplas questões pertinentes à docência universitária, isto é, precisei conhecer os dilemas que envolviam a tarefa de exercer a docência no ensino superior, dentre eles a de ser formadora de professores. Essa temática logo me capturou e, daí em diante, passou a me interessar mais diretamente. Comecei a 
perceber que nesse nível de ensino havia muitas questões não resolvidas sobre o complexo processo de ensinar e aprender e que, em algumas áreas, tais questões sequer eram problematizadas.

Trabalhei em duas outras universidades, sendo que em uma especificamente no curso de Direito. Nesta, as discussões em reuniões pedagógicas, as questões de ensino e aprendizagem nem eram levantadas. As reuniões serviam apenas para informações sobre o curso, tais como número de alunos matriculados, forma de preencher o caderno de chamada e eventos que o curso promoveria.

A experiência foi me ensinando que a maior parte dos problemas e das dificuldades que professores e alunos universitários enfrentam em seu cotidiano comprometendo a função educativa e mesmo a qualidade de ensino de graduação devia-se, por um lado, à ausência de um compartilhamento de experiências formativas oriundas de projetos claros sobre que profissionais e cidadãos cada curso pretendia formar e, por outro, à dificuldade de os professores se reconhecerem como docentes desses cursos.

Parti, então, para minha primeira pesquisa, na universidade em que atuo, sobre formação de professores de ensino superior. Encontrei docentes que iniciaram a prática da docência respaldada apenas em saberes e fazeres adquiridos no senso comum e na experiência vivida como alunos universitários. Percebe-se que, desde o princípio de suas atividades, a inteira responsabilidade de cátedra, sem contar com o apoio de professores mais experientes (nos depoimentos essa foi uma constante, pois a maioria chega à instituição sem experiências anteriores e se sente solta, desamparada): recebem a ementa da disciplina e outras regras gerais.

Ao longo das histórias de vida desses professores, foi possível perceber que a maior parte deles se sentia engajada na reconstrução de sua própria docência, na procura cursos de capacitação, especialização, aperfeiçoamento, mestrado e doutorado, pois percebia que as dimensões pessoal e profissional estão entrelaçadas. Essa compreensão reforçou a perspectiva de que é inútil estudar o docente sem levar em conta sua construção como pessoa articulada com a sua formação profissional. Percebi, em congruência com esse posicionamento, que os docentes que fizeram parte dessa pesquisa informaram que ao longo de suas carreiras enfrentaram crises, problemas, inseguranças, tensões, limitações e angústias. Esses fatores levaram-nos a ressignificar suas vidas em termos pessoais e profissionais. 
A experiência vivida encontra similaridade com o pensamento de Nóvoa (1992), para quem o foco da docência engloba as diferentes atividades desenvolvidas pelos docentes, orientados para a preparação de futuros profissionais. Essas atividades são regidas pelo mundo da vida e da profissão, alicerçadas não só no conhecimento, nos saberes e fazeres, mas também em relações interpessoais e vivências de cunho afetivo, valorativo e ético, indicando que a atividade docente não se esgota na dimensão técnica, mas remete ao que de mais pessoal existe em cada docente.

De certo modo, as pesquisas que realizei nos primeiros anos de atividade docente no ensino superior possibilitaram-me olhar para minha incompletude formativa e propiciaram reflexão e análise em relação às experiências e vivências que foram se construindo por meio de um processo de relações que são profissionais e pessoais. A compreensão sobre minha profissionalidade foi se constituindo cotidianamente.

Pensar a partir de achados e discussões provenientes das pesquisas e vivências, as quais obtive durante esses anos, instigou-me a admitir que o professor universitário precisa muito mais do que dominar conteúdos. Logo, é nesse movimento permeado de reflexões decorrentes das pesquisas que participei e realizei, de minha experiência como professora no ensino superior, como professora formadora de professores, que o inacabado da minha formação se revela.

O fato de ser docente formadora de professores subentende compreender 0 processo ensino-aprendizagem em diferentes realidades. Assim, refletindo acerca da docência de ensino superior e de como ocorreu meu ingresso na docência, nasceu o interesse em conhecer outros profissionais da área de formação de professores, em especial os que trabalham com as disciplinas conhecidas como matérias pedagógicas,ou seja, Didática e Didáticas Específicas, na mesma universidade em que atuo.

Paulo Freire (1996) ao falar dos saberes necessários à prática educativa, chamou atenção para aspectos significativos e outras dimensões igualmente importantes, sobretudo em um contexto de prática reflexiva crítica. Para ele, o professor, como profissional e ser situado histórico-culturalmente, produz uma prática pedagógica que pode se tornar cada vez mais rica e significativa, se forem considerados saberes que dizem respeito a ações pedagógicas coerentes com uma opção político-pedagógica democrática ou progressista. 
Nesse sentido, simultaneamente às leituras realizadas como integrante de grupos de pesquisa durante a formação de pós-graduada, minha atividade docente colocava-me frente a grupos de professores iniciantes e outros com anos de atividade, possibilitando-me presenciar distintas trajetórias de formação nessas disciplinas.

Colabora nesta reflexão a atividade de docência que venho realizando desde 2003, no curso de Pedagogia, que é de orientação e supervisão nos estágios, além das disciplinas pedagógicas para todos os cursos de licenciatura. Nesse lugar, encontrei o objeto desta pesquisa, pois nos estágios é que podemos perceber alguns indicativos com relação à apropriação do conhecimento teórico e da prática aprendida pelos futuros professores. As disciplinas de didática oportunizam aos alunos que conheçam estratégias para o processo de ensino-aprendizagem e, assim, entrelaçam-se com a prática. Nesse lugar senti que essa aprendizagem não é tão linear e previsível assim. Logo, algumas questões foram surgindo, constituindo-se a cada semestre, a cada leitura, no contato com alunos e colegas. Tudo foi possibilitando mais conhecimento acerca dessa relação e instigando mais inquietações.

Nesse contexto, busquei conhecer quem é o docente que forma professores e, em torno desse questionamento, perguntei-me sobre sua formação, buscando saber como esse professor aprendeu a ser docente no ensino superior e como vem desenvolvendo suas aulas. Fui instigada a obter informações sobre como o docente formador interage com os conhecimentos específicos de sua área de formação, e de como esse docente organiza o espaço de formação dos futuros professores.

Cada espaço em que atuei explicitava concepções de conhecimento e de aprendizagem que colaboraram para a construção da minha profissionalidade. Diante desse cenário e de outros tantos momentos significativos da minha trajetória profissional, percebi que as experiências me ofereciam subsídios para refletir sobre a pedagogia universitária, bem como acerca dos saberes necessários à docência superior. 


\section{A UNIVERSIDADE: CENÁRIO DA FORMAÇÃO DE PROFESSORES E DA DOCÊNCIA NOS CURSOS DE LICENCIATURA}

O lócus desta investigação é a universidade. Trata-se do espaço em que me movimento, junto com meus pares e com os estudantes, para a realização do trabalho de formação a que todos nos dedicamos. Portanto compreender um pouco de sua história e principalmente de seu contexto contemporâneo pareceu imprescindível para a ambientação deste estudo.

\subsection{A universidade no Brasil: contextos contemporâneos}

Ao longo do seu desenvolvimento, o ensino superior tem passado por expressivas transformações e substanciais modificações, mas, talvez, nunca a responsabilidade social tenha estado tão em evidência como atualmente.

Num mundo em constante e acelerado processo de renovação, as estruturas e funções tradicionais da universidade se deparam com uma série de desafios, exigindo múltiplas energias e o enfrentamento de novas possibilidades com vistas a encarar as configurações da sociedade contemporânea e, principalmente, do futuro.

Muito se tem escrito e debatido sobre a função da universidade e, em geral, a ênfase tem se centrado em seu papel de produtora e transmissora de conhecimento. Entretanto vale perguntar: como a universidade vem cumprindo esse papel? Que tipo de conhecimento vem produzindo e, principalmente, como o tem socializado? Como os docentes de ensino superior refletem sobre essa responsabilidade? Por que acreditamos que a contribuição da universidade não deve se limitar somente a prover a sociedade de recursos humanos adequadamente qualificados para o desenvolvimento socioeconômico?

O acadêmico, ao adquirir conhecimentos necessários para exercer uma atividade específica em uma sociedade que requer seus serviços e sua participação, deve ser capaz de responder às expectativas nele depositadas mediante a concretização de um compromisso não só com ele mesmo, mas com a sociedade como um todo. E é na universidade que esses fundamentos de estreita relação entre o profissionalismo e o respeito ao ser humano e aos seus direitos deve solidificar-se, na busca de uma sociedade mais justa. 
A centralidade dos estudos sobre ensino superior no Brasil se refere especialmente às instituições públicas, como lembra Martins (1989). São escassos os estudos específicos que abordam aspectos das instituições de ensino superior privadas (IESP), e geralmente esses trabalhos têm tratado das condições econômicas, políticas e ideológicas que propiciaram sua expansão. No período anterior à expansão das IESP não confessionais, antes da emergência dos governos militares no Brasil, havia, segundo Florestan Fernandes (1966) um padrão nacional de escola superior dessa natureza: isolada, especializada e autárquica, tanto em nível da rede oficial quanto da rede privada. Isolada, porque mesmo as universidades eram construídas basicamente como um feixe de escolas e faculdades autárquicas desprovidas de estrutura integrativa.

De acordo com Sobral (1993) nos anos 1950 e em meados da década de 1960, a educação vinha sendo considerada como um instrumento de mobilidade social. Por isso, tinha como função, além da socialização e da formação, a contribuição para que o indivíduo almejasse mais status. Os estudos universitários passaram a ser requeridos como um instrumento de mobilidade social, principalmente para a classe média. Cabe ressaltar que, até essa época, a universidade tinha como objetivos a formação de profissionais liberais e de uma elite culta. Nesse período, a atividade docente de ensino superior operava sobre as bases da cátedra. O professor catedrático regia uma hierarquia de magistério e tendia a converter todos os demais docentes em seus ajudantes pessoais. Muitas instituições de ensino superior (IES) cresceram com a presença de destacados catedráticos em seu quadro docente, e estes ocuparam um importante papel na estruturação do ensino superior brasileiro.

Tanto Ribeiro (1969) quanto Fernandes (1966) destacam que a maioria dos profissionais passava poucas horas semanais nas faculdades. Em função de serem profissionais liberais, priorizavam a carreira vinculada ao curso de formação profissional e exerciam a docência no ensino superior como uma função secundária. Florestan Fernandes (1966) lembrava que o professor catedrático estava mais interessado em suas atividades fora da faculdade, seja em escritório ou consultório, do que na atividade como docente. O campo do ensino superior brasileiro parecia não estar preparado para a oferta de posições docentes de caráter mais profissional, pois o processo de desenvolvimento do país não exigia a formação de recursos 
humanos de maneira ampla e diversificada que levasse, por sua vez, à necessidade de uma maior profissionalização.

A reforma universitária no período do governo militar procurou associar modificações do ensino superior com as diretrizes de desenvolvimento econômico então vigentes, pautadas pela perspectiva de formação de recursos humanos no anseio de um progresso técnico, sob as bases de uma sociedade brasileira que se internacionalizava, nos moldes ideológicos norte-americanos. Oliven (1987) afirma que a principal causa da reforma universitária foi a necessidade de cooptação da classe média que endossou o movimento de 1964. A autora salienta que a universidade brasileira estava inadequada ao capitalismo associado que estava sendo implantado no país e que. Por esse motivo, a modernização estimulada pela reforma era interessante para os empresários, para as empresas multinacionais e para a burocracia estatal. Portanto esses fatores abriam um novo mercado de trabalho que passou a ser disputado pela classe média. O diploma de ensino superior constituiu-se em uma garantia de acesso ao mercado de trabalho.

Corrobora nesse sentido o relato de Sampaio (1991), no qual enfatiza que o ensino superior, nesse período, se tratava de um sistema que assegurava um diploma profissional, o qual dava direito a ocupar posições privilegiadas no restrito mercado de trabalho e a assegurar prestígio social.

Com isso, valorizou-se a formação de um corpo docente - em especial nas IES particulares -, desarticulado de qualquer tipo de contestação ideológica ao regime implantado pelos militares a partir de 1964, estando o máximo possível imbuído da ideologia desenvolvimentista então em voga. As considerações políticas e ideológicas, além das considerações econômicas, pouco estiveram presentes na estruturação das IES particulares e de seu corpo docente. Em geral deveriam elas ter um corpo docente destituído de contestação política, na visão do governo militar. Desse modo, as IES particulares foram se estruturando tendo como um dos fundamentos de legitimidade social o respeito à ordem da esfera pública, refletindose na própria composição do quadro docente.

Diante da reticência das IES católicas em atender à demanda do governo pela expansão do ensino superior, basicamente a iniciativa privada, que atuava no primeiro e no segundo grau de ensino, passou a deslocar seus investimentos para o nível superior, que prometia ser fecundo em relação à rentabilidade econômica. Como consequência, o ensino do terceiro grau foi influenciado pela mesma lógica de 
funcionamento presente no primeiro e no segundo grau, em uma perspectiva expansionista.

Podem-se apontar alguns elementos associados ao interesse desse projeto em relação à reforma do ensino superior realizada pelo governo militar. Um deles refere-se à transformação da unidade básica dos institutos centrais e das faculdades, que deixou de ser a cátedra para ser o departamento, integrando em uma equipe todo o corpo docente:

\begin{abstract}
Enquanto o regime de cátedras caminhava para a extinção, duas importantes medidas foram promulgadas em 1965, ambas para institucionalização da carreira docente. A Lei 4.881-A definiu, pela primeira vez no país, um Estatuto do Magistério Superior Federal. Sintonizadamente, o Conselho Federal de Educação aprovou o parecer 977 por solicitação ministerial, a fim de regulamentar os cursos de pós-graduação previstos na Lei de Diretrizes e Bases da Educação Nacional, mas ainda não sujeitos a critérios de credenciamento. (DURHAN,1998, p.89).
\end{abstract}

De acordo com Cunha (1982, p.89), os motivos principais para tal regulamentação foram os seguintes:

1) formar professores competentes que pudessem atender à expansão quantitativa do ensino superior, garantindo, ao mesmo tempo, a elevação dos níveis de qualidade; 2) estimular o desenvolvimento da pesquisa científica por meio da formação adequada de pesquisadores; 3) assegurar a formação de quadros intelectuais do mais alto padrão para fazer frente às necessidades do desenvolvimento nacional em todos os setores.

O autor afirma que já havia naquela época a ideia, que foi ficando cada vez mais forte, de que a expansão do alunado nos cursos de graduação implicava a degradação de sua qualidade (ibidem). Entretanto a pressão das classes médias pelo ensino superior aumentava significativamente. Em 1965, o número de alunos do ensino superior apresentou um crescimento rápido, chegando a 67\%, quando comparado com o início da década, sendo que o número de candidatos aos exames vestibulares aumentou essa taxa ainda mais.

Outro aspecto a ser considerado foram as aproximações setoriais do mundo universitário: a universidade passou a ser vista sob o ângulo das políticas de financiamento, ou da adequação de seus planos de estudo às demandas da sociedade, ou dos sistemas de seleção e promoção dos professores, ou da imagem social, ou das características dos alunos que têm acesso aos estudos superiores. Sobre esses aspectos, pode-se observar uma abundante produção de estudos. Porém continuou faltando um olhar mais interior que permitisse compreensões mais intensas do cotidiano acadêmico e do sentido e da dinâmica por ele proposto. 
Essas considerações indicam a emergência de se ampliar o olhar investigativo às universidades privadas. Essas universidades continuam em franco desenvolvimento, por diferentes motivos, tais como: a interiorização com a aproximação nos centros pequenos, que propicia aos alunos cursarem uma universidade sem ser necessário viajar ou se instalar na capital; a oferta de bolsas e/ou descontos para os cursos de licenciaturas; a oferta de cursos durante as férias e cursos aos finais de semana. Esses fatores precisam ser investigados para melhor compreensão dessas instituições.

Os estudos de Martins (1989) enfatizam que o ensino superior brasileiro possui um campo complexo, com dimensão multifacetada, formado por instituições públicas e privadas. $\mathrm{O}$ autor ressalta que existem diferenças marcantes, não apenas entre as instituições públicas e privadas, mas também no interior de cada um desses segmentos:

\begin{abstract}
A diversidade institucional está presente também no subcampo das universidades privadas, integrado basicamente pelas instituições comunitárias, pelas confessionais e pelos estabelecimentos de perfil mais empresarial, uma vez que é possível constatar nesse segmento uma multiplicidade de projetos acadêmico-institucionais. As universidades comunitárias, de modo geral, apresentam um trabalho bastante inovador na prestação de serviços educacionais à comunidade, mantendo um elevado grau de interação no seu contexto social. Elas estão voltadas fundamentalmente para as atividades de ensino e desenvolvem um trabalho significativo no domínio da extensão. Como se sabe, até o final da década de 60 , as universidades confessionais possuíam maior peso no conjunto do setor privado nacional e estavam praticamente ligadas à Igreja Católica. A presença do ensino privado confessional não era desprezível, porque respondia, na metade daquela década, por aproximadamente $44 \%$ das matrículas. Em período mais recente, houve a criação de certas instituições confessionais não católicas, especialmente metodistas e luteranas. Deve-se destacar que determinadas universidades confessionais, de modo especial algumas PUCs, têm desenvolvido suas atividades pautadas por consistentes padrões acadêmicos. (ibidem, p. 64-65).
\end{abstract}

Como aponta a bibliografia referente a essa questão, chama a atenção que nos anos 1970 o processo expansionista das instituições privadas não foi nas de cunho confessional, mas marcou o aparecimento de um 'novo ensino privado', de perfil laico, que se constituiu a partir do final dos anos 1960, comandado por uma lógica de mercado e um acentuado ethos empresarial. Como já foi assinalado, a partir do final dos anos 1980 ocorreu um movimento para transformação de escolas isoladas e/ou federações de escolas em universidades particulares, em grande parte guiado por esse 'novo ensino privado'. Conforme indica Martins (1989, p. 66): 
As informações disponíveis sugerem que a lógica para a criação das novas universidades particulares, cujo crescimento foi de $280 \%$ nos últimos 20 anos, foi influenciada pela fusão de estabelecimentos isolados, que decresceram durante esse período, e/ou pela criação de faculdades integradas particulares, as quais funcionaram como uma espécie de incubadora de novas universidades, aumentando sua participação quantitativa no sistema de forma significativa. Acredita-se que a expansão recente das universidades particulares foi conduzida pelo interesse de suas mantenedoras em obter maior autonomia, conferida legalmente a esse tipo de instituição, principalmente a liberdade de expandir seus cursos e ampliar as vagas existentes. Expressa também uma estratégia, direta ou indireta, de maximizar simbolicamente a posição dessas instituições no interior do campo acadêmico vis-à-vis com estabelecimentos não universitários, procurando demarcar posições e aumentar a rentabilidade simbólica dos seus títulos escolares nos mercados acadêmico e extra-acadêmico. (MARTINS, 1989, p. 66).

Outra contribuição nesse sentido, de acordo com Klein (1992) se inicia na década de 1960, quando o setor privado se torna o maior responsável pela expansão do ensino superior no Brasil, tendo registrado, entre 1960 e 1980, um significativo aumento no número de alunos matriculados, que passou de $44 \%$ para $63 \%$ do total. Esse setor se caracteriza, em sua maioria, por instituições isoladas que se mantinham com as mensalidades cobradas dos alunos. Os estudos indicam que o crescimento do ensino superior privado se desenvolveu em um processo com três características principais: a disputa de um mercado por uma clientela restrita em função da estagnação da população universitária brasileira, a descentralização e a expansão de IES pelo interior dos estados e a articulação de instituições isoladas e suas transformações em universidades.

Outra característica das instituições privadas levantada por Martins (1991) refere-se à sua localização, pois são construídas em bairros que abrigam escritórios, bancos, comércio, de fácil locomoção, com a intencionalidade de atender a esse mercado potencial e atrair estudantes-trabalhadores para os seus cursos noturnos. Esses estudos apontam que, já nas décadas de 1950 e 1960, verificou-se um significativo aumento no setor do ensino privado, tanto em relação ao número de alunos matriculados quanto em número de instituições. Essa expansão das universidades privadas deveu-se também ao fato de existir uma demanda de alunos que não eram atendidos pelo setor estatal. O ensino superior garantia o acesso da classe média ao novo mercado de trabalho surgido no final da década de 1960, decorrente da ampliação das empresas de grande porte se instalando no país. Com relação à organização interna, essas instituições assumiram especificidades, representando modos de ser e respondendo aos compromissos anunciados às suas 
comunidades e aos interesses que representam. Referencio a representação dessa organização institucional utilizada por Almeida (2001, p. 216) em seus estudos sobre as novas universidades em São Paulo:

O modo brasão atende à demanda social, os que de maneira mais
complexa, sendo produzindo conhecimento e reflexão com compromissos
sociais. O modo logotipo absorve a demanda de forma utilitária, procurando
em função da ausência de produção de conhecimento, afirmar-se na oferta
de produtos correlatos e na utilização de tecnologia e computadores como
fim. O modo brasão, também com acesso a novas tecnologias, utiliza-se
desse aparato como complemento, como meio.

Almeida (ibidem) salienta que as universidades 'logotipo' possuem a característica administrativa peculiar, pois o reitor é um profissional. Mesmo que sob controle de um dono, é um gerente que administra recursos. Diferencia-se das gestões acadêmicas tradicionais, em que os reitores em geral são escolhidos pela meritocracia, ou seja um reitor professor-doutor, que desenvolveu uma reconhecida vida acadêmica. O brasão representa um compromisso com a sociedade e o logotipo expressa o compromisso com os grupos ou grupo de mantenedoras.

Percebe-se que nesse modo de ver as universidades pode haver uma valoração mais centrada na razão instrumental, ou seja, propiciar aos alunos o conhecimento necessário para colocá-los no mercado de trabalho. Rompe-se, assim, com a concepção de que o ensino superior tenha de oferecer à sociedade uma contribuição significativa, em que a produção do conhecimento esteja articulada com os problemas sociais dos locais onde essas universidades estão inseridas.

A proposta da autora estimula a olhar para a universidade privada nos aspectos que afetam a docência e a formação de professores na e para a universidade, nessa dinâmica e interface.

É importante salientar que as universidades, durante seus vários séculos de história, sofreram modificações em sua orientação e projeção social. Contudo essa dinâmica de adaptação constante às circunstâncias e às demandas da sociedade acelerou-se neste último meio século, tornando quase impossível um ajuste adequado sem uma transformação profunda das próprias estruturas internas da universidade. Por um lado, há a pressão da globalização e internacionalização dos estudos e dos pontos de referência, tais como: sistema de avaliação, níveis de referência, política de pessoal etc. Por outro lado, cada vez mais se registra a importância do contexto em que se situa a prática acadêmica. Cada instituição está condicionada pelo contexto político, social e econômico, gerando condições que a 
tornam única e diferenciada. Ao mesmo tempo, tem de responder a padrões de qualidade externos, que são generalistas e universais.

Cunha (2007) destaca dois aspectos que vêm caracterizando o ensino superior no Brasil: a privatização e a fragmentação institucional. Segundo o autor, cerca de $58 \%$ dos estudantes de graduação estão matriculados em instituições privadas. Dentre elas, predominam as faculdades isoladas e as associações de faculdades, sendo as instituições universitárias a minoria. Na época em que seus estudos foram produzidos, eram 27 as instituições confessionais, das quais 24 católicas e três protestantes. Ao encontro dessa afirmação, segundo os dados do Instituto Nacional de Estudos e Pesquisas Educacionais Anísio Teixeira (INEP, $2010)^{2}$ ligado ao Ministério da Educação (MEC), as instituições privadas possuem $58,84 \%$ de matrículas em cursos na área de educação na modalidade presencial e 36,68 na modalidade a distância.

Esses dados parecem justificar por si sós a emergência de estudos nas universidades privadas, em especial nos cursos de formação de professores. Tais universidades continuam em franco desenvolvimento, por diferentes motivos, como: a interiorização com a aproximação nos centros pequenos, que propicia aos alunos cursarem uma universidade sem ser necessário viajar ou se instalar na capital; a oferta de bolsas e/ou descontos para os cursos de licenciaturas; a oferta de cursos durante as férias e cursos aos finais de semana. Esses fatores precisam ser investigados para melhor compreensão das IESP.

Trabalhar com a formação de professores é lidar com o intrincado processo no qual o tema está inserido. Este é diretamente ligado à temática da qualidade na educação, presente nos mais variados locais e discursos, sendo motivo de encontros entre lideranças políticas e educacionais do Brasil e do mundo todo.

Cada instituição de ensino busca a qualificação dos serviços que presta, ao mesmo tempo em que adota princípios administrativos que aumentem a produtividade, dinamizando processos, sem com isso deixar de atender às exigências legais referentes ao sistema de ensino do país em que se encontra.

No Brasil, a necessidade de ampliação da educação superior manifesta-se como um sintoma das mudanças que afetam uma série de países que estão no mesmo estágio, ou que se assemelham em termos de desenvolvimento educacional.

\footnotetext{
${ }^{2}$ Disponível em: <http://www.mec.gov.br>. Acesso em: 10 de out. 2013.
} 
Para Morosini (2000), o sistema de educação superior no Brasil, apesar da baixa taxa de escolarização apresentada no país, possui os maiores números da América Latina, sendo o número de matriculados maior nas instituições de ensino privado do que nas instituições de ensino público.

Tal fato tornou-se possível na medida em que o Plano Nacional de Educação vem insistindo com $\mathrm{o}$ aumento significativo da oferta de vagas e com 0 acompanhamento pelo Conselho Nacional de Educação (CNE/MEC), mas também através da autorização de novos cursos e instituições privadas de ensino, reduzindo o papel do Estado ao financiamento da educação universitária.

O quadro apresentado pelo INEP ${ }^{3}$ sobre a educação superior brasileira entre os anos de 1991-2004 nos traz de forma clara a situação do estado do Rio Grande do Sul nesse contexto. Conforme os dados expostos, o crescimento do número de instituições de ensino superior no Brasil é mais significativo na Região Sul. Contudo o Rio Grande do Sul não apresenta o mesmo crescimento que os demais estados.

Especificamente para a Região Sul e para o estado do Rio Grande do Sul, o Censo da Educação Superior do INEP de 2004 registra que:

[...] 2.013 instituições de educação superior (IES) - destas, 335 (16,6\% estavam instaladas na região sul. O Rio Grande do Sul apresentava 83 IES, o que representava $4,12 \%$ em relação ao Brasil e $24,77 \%$ em relação à região sul. [...] Das 83 IES do Rio Grande do Sul, as públicas são 9 (10,8\%) e as privadas são $74(89,2 \%)$. Das 9 IES públicas, 8 são federais e 1 estadual. Das privadas, 35 são particulares e 39 comunitárias/ confessionais/filantrópicas. Quanto à organização acadêmica, o Estado do Rio Grande do Sul tem 16 Universidades, 6 Centros Universitários, 1 Faculdade Integrada, 52 Faculdades, Escolas e Institutos Superiores e 8 Centros de Educação Tecnológica e Faculdades de Tecnologia. (ibidem, p. 31).

Felizmente, o Censo da Educação Superior, realizado entre os anos de 2001 e 2010, apresenta um crescimento significativo no número de matrículas em cursos de graduação no Brasil. A participação das IES privadas é ainda muito significativa. Entretanto, "apesar do caráter preponderantemente privado da expansão ao longo desse período, tais resultados apontam para certa estabilização da participação desse setor, que, em 2010, representa $74,2 \%$ das matrículas” (2011 p. 8).

O censo de 2009 (BRASIL, 2009) registrou 2.314 IES, sendo 2.065 privadas e 245 públicas. Na matrícula, cujo total é de 5.954.021, constam 5.115.896 estudantes universitários em cursos presenciais, o que indica a prevalência dessa modalidade

\footnotetext{
${ }^{3}$ Disponível em: <http://www.mec.gov.br>. Acesso em: 10 de out. 2013.
} 
sobre a educação a distância (EAD), embora esta tenha registrado um aumento de 30,4\%. A distribuição das matrículas nas IES evidencia que 4.430157 estudantes estão em IES privadas e os demais, isto é 1.523 .864 , são distribuídos no setor público, nas IES federais, estaduais e municipais.

Quanto aos docentes, o Censo de Educação Superior de 2009 registrou um total de 307 mil no ensino superior no Brasil, dos quais 36\% são mestres e $27 \%$ são doutores. A proporção de mestres e doutores, de acordo com esse censo, é maior nas universidades públicas $(75 \%)$ do que nas privadas $(55 \%)$. No que se refere à titulação, nas IES públicas quase metade dos professores $(48 \%)$ tem o grau de doutor, enquanto nas privadas a maior concentração é de mestres (41\%).

Também esses dados indicam que o docente da instituição privada é geralmente jovem, com idade média entre 30 e 35 anos, com mestrado e contratado por hora-aula. Essa condição de professor horista é um dos problemas enfrentados pelos docentes, pois gera instabilidade tanto em relação à permanência na instituição quanto à carga horária semestral.

O fato é que o ensino superior no Brasil está vivenciando um momento histórico de expansão, em que se mantém a dualidade entre o público e o privado, marcada desde a sua origem.

Na compreensão de Souza Santos (1997,p. 188)," há uma correlação entre a explosão das funções e a explosão da universidade, do aumento dramático da população estudantil e do corpo docente, da proliferação das universidades, da expansão do ensino e da investigação universitária a novas áreas do saber."

Esses dados procuraram informar sobre o cenário da educação superior no Brasil, com o objetivo de compreender os espaços-tempos em que o estudo objeto desta investigação se instituiu. Não tive a intenção de esgotar o tema, mas de indicar alguns aspectos que favoreçam a compreensão do objeto analisado.

\subsection{Docência universitária: entre a tradição e a inovação}

Muitos estudos têm sido realizados sobre a universidade brasileira, desvelando sua trajetória nas condições históricas que explicitam a organização de seus cursos e análise sobre legislações. Sem dúvida esses estudos contribuem para abrir caminhos e reflexões, no entanto ainda não são tantos os que exploram a formação pedagógica e a prática cotidiana do professor universitário. 
As produções sobre a formação de professores têm ressaltado especialmente pontos como: saberes e competências do ofício; compreensão sobre o desenvolvimento profissional do professor; modelos de formação; identidade docente; profissionalização docente e práticas reflexivas. A formação de professores, nesse contexto e mediante o cenário de mudanças, inclina-se para um perfil de professor que considera a aprendizagem como um desafio permanente, em que os saberes e as competências são aprendizagens realizadas ao longo da vida, no âmbito da escola e fora dela.

Quando se incide o olhar sobre a formação de professores, é importante a perspectiva da profissionalidade na ação docente. Para Giméno Sacristán (1995), essa condição diz respeito ao resgate da imagem do professor como intelectual, como o detentor de um discurso que é incorporado por elementos técnicos, que exprimem as componentes políticas que determinam a prática docente.

Com relação à formação e à preparação do professor universitário para o exercício de ensinar, estudos como os de Marcelo Garcia (1999), Balzan (2000), Masetto (2000), Morosini (2000), Anastasiou (2002), Cunha (2001), Pimenta e Anastasiou (2002) Isaia e Bolzan (2009), dentre outros, sustentam a afirmativa de ainda tem sido pouca a atenção dada a esse enfoque.

De acordo com Masetto (2002) a formação para o exercício da docência, mais especificamente para o ensinar no ensino superior, não tem uma longa história de investimento, tanto por parte dos profissionais quanto de espaços e agências formadoras. No Brasil, somente aparece há cerca de duas décadas, em decorrência de uma autocrítica por parte de diversos segmentos do ensino superior, principalmente dos professores. Assim, podemos constatar que o saber para ensinar - saber das ciências da educação - por muito tempo foi visto como um simples complemento dos saberes disciplinares.

Portanto os processos de aprendizagem e os saberes próprios à docência eram deixados em segundo plano, partindo da premissa do 'aprender fazendo' ou da concepção de que quem tem domínio do conhecimento específico sabe ensinar.

Enfatiza Tardif (2002) que os saberes profissionais são temporais, no sentido de que os primeiros anos de prática profissional são decisivos na aquisição do sentimento de competência e no estabelecimento das rotinas de trabalho, na estruturação da prática profissional. Para o autor, os professores, quando começam a trabalhar, são movidos pelas crenças adquiridas antes das suas graduações. Foi 
observado nas pesquisas de Raymond, Butt e Yamagishi (1993), citados por Tardif (2002), que quando ocorriam problemas de disciplina em sala de aula a tendência dos professores era reativar modelos de solução de conflitos que viveram nas suas histórias familiares ou escolares.

Tardif (2002) afirma que os saberes, conhecimentos construídos pelos professores, são temporais, plurais e heterogêneos, personalizados e situados. Isso porque são construídos ao longo da trajetória, no cruzamento das histórias de vida e da escolarização dos professores; não têm uma única fonte, mas se compõem da diversidade de contextos, de culturas (pessoal, escolar, institucional, da categoria profissional a que pertence); são conhecimentos das disciplinas, pedagógicos, curriculares, experienciais, apropriados nas relações, nas práticas concretas; são subjetivos porque incorporados, elaborados pelos sujeitos que nele imprimem sua marca.

Esse modelo da racionalidade prática percebe o processo de formação do professor como contínuo e o próprio docente como sujeito ativo de seu desenvolvimento profissional. Nessa formação, os saberes e as competências docentes são resultados não só da formação profissional e do exercício da docência, mas também de aprendizagens realizadas ao longo da vida, dentro e fora da escola (MIZUKAMI et al., 2002) Em tal perspectiva, pode-se supor que o desenvolvimento profissional do docente envolve valores, ideais, afetos, crenças, experiências, interesses e práticas sociais, profissionais e políticas.

A pesquisa de Marcelo Garcia (1999) indaga sobre os processos pelos quais os professores geram conhecimento, além de sobre quais tipos de conhecimentos adquirem. Esses estudos buscam entender como o indivíduo vai se tornando professor ao longo de sua trajetória de vida, questionam sobre o que os docentes conhecem e como adquirem os conhecimentos da profissão.

As pesquisas realizadas apontam que a identidade profissional é alcançada a partir de uma construção que perpassa a vida profissional, desde a escolha da profissão, até os diferentes espaços institucionais onde se desenvolve a profissão e os distintos ciclos de desenvolvimento da carreira.

Pimenta (2006) ressalta que a identidade profissional do professor deve ser construída a partir da revisão das tradições e da significação social da profissão, do confronto teórico-prático, das análises sistemáticas das práticas à luz das teorias, do 
significado que cada um dá à sua atividade, das representações dos futuros professores, bem como das relações estabelecidas com outros profissionais.

Portanto o professor, enquanto profissional, está em constante construção. Cabe-nos reconhecer e identificar quais são os fatores que interferem na constituição dessa profissionalidade docente capaz de responder aos desafios colocados ao ensino superior frente às mudanças pelas quais passa a universidade brasileira. Têm-se como considerações, a partir dessa vivência, que esses profissionais entendem que a qualidade da docência se vincula à profissionalidade e que, para que isso seja possível, é necessário, além de um sólido conhecimento na área específica, a atualização também no campo da docência, da prática pedagógica. Atualmente, entretanto, esses critérios não bastam, pois o professor tem de ser inovador, tem de reinventar sua prática para acompanhar as mudanças do mundo contemporâneo.

Compreende-se a docência como uma relação que visa a perceber a importância da formação ética e humanista dos alunos, da interação professor-aluno e aluno-aluno, da clareza e organização das exposições, da necessidade de adequação da linguagem usada em sala de aula, das especificidades do ensino em sua área - articulando conhecimento, habilidades e atitudes -, do uso adequado das tecnologias à disposição do ensino, entre outras questões. Assim, o professor pensa, organiza, constrói uma intervenção pedagógica atento à complexidade das determinações que atravessam sua prática pedagógica.

Nóvoa (1991) aborda a gênese e o desenvolvimento da profissão docente em sua relação com a gênese e o desenvolvimento da instituição escolar. Nessa direção, a trajetória dos sistemas de ensino e da escola tende a sofrer significativas transformações nos momentos de transição das sociedades, provocadas pelos modelos culturais, sociais e econômicos vigentes em cada época. Conforme o autor, a história da profissão docente lida com uma série de mudanças e, hoje, ganha novos contornos, a partir de amplo debate em torno da necessidade de redefinição da função educativa, buscando elucidar as seguintes questões, entre outras: quem são os alunos? Quem são os professores? Qual é o papel da escola? O que ensinar? Essa reflexão também está presente na universidade, que é o local de formação desses profissionais.

Desvendar os sentidos da formação desses docentes requer observar a sintonia que há entre o conhecimento teórico-prático adquirido nesse processo e as 
necessidades da escola de hoje. Portanto os desafios na área de formação de professores são inúmeros. Os processos formativos não se dão no abstrato, porque são destinados a profissionais que, como os demais trabalhadores, têm tido suas condições concretas de existência acentuadamente deterioradas. Assim, é nessa realidade social que a formação se desenvolve e é na sua complexidade e nas suas contradições que atuam as escolas.

Para que se possa compreender o processo de como se manifesta a atuação dos professores universitários na prática, é necessário levar em conta, primeiro, sua história de formação, a partir do conjunto de atuações, conhecimentos, atitudes e valores ligados a ela que constituem o específico de ser professor na universidade.

Uma identidade profissional se constrói, pois, com base na significação
social da profissão; da revisão constante dos significados sociais da
profissão; da revisão das tradições. Mas também com base na reafirmação
de práticas consagradas culturalmente e que permanecem significativas. [...]
Constrói-se, também, pelo significado que cada professor, enquanto ator e
autor, confere à atividade docente no seu cotidiano, com base em seus
valores, em seu modo de situar-se no mundo, em sua história de vida, em
suas representações, em seus saberes, em suas angústias e anseios, no
sentido que tem em sua vida o ser professor. Assim como mediante sua
rede de relações com outros professores, nas instituições de ensino, nos
sindicatos e em outros agrupamentos. (PIMENTA; ANASTASIOU, 2002 p.
77).

As autoras consideram que muitos profissionais de campos de conhecimento variados adentram o campo da docência no ensino superior por consequência de sua atuação em áreas específicas. Trazem consigo uma bagagem significativa de conhecimento, porém nem eles nem as instituições que os contratam os fazem perceber o que realmente vem a ser 'professor'.

Afinal quem é o professor do ensino superior? De acordo com Franco (2000), citado por Morosini (2001), o professor universitário caracteriza-se pela diversidade, pela pluralidade de opções, caminhos, alternativas, interesses e tensões. $O$ movimento de construção da identidade profissional pressupõe um processo, o qual também acompanha a construção de um ser enquanto pessoa e profissional, ambos influenciados pelo contexto institucional e social em que estão inseridos. É o olhar reflexivo que também promove uma compreensão do trabalho docente como uma tarefa permeada de responsabilidades, atitudes, relações e crescimentos.

A formação deve estimular uma perspectiva crítico reflexiva, que forneça aos professores os meios de um pensamento autônomo e que facilite as dinâmicas de autoformação participada. Estar em formação implica um investimento pessoal, um trabalho livre e criativo sobre os percursos e os 
projectos próprios, com vistas à construção de uma identidade, que é também uma identidade profissional. (NÓVOA, 1992, p. 25).

Corroborando a posição de Nóvoa, Shön (1992) e Tardif (2002) apontam para uma epistemologia da prática, fundamentada na reflexão do profissional sobre a sua ação. Pode operar uma possível mudança na formação docente, capaz de ajudar o professor a encontrar respostas aos dilemas que o exercício profissional the impõe.

Vale ressaltar, também, que as experiências, os saberes, os conhecimentos que o professor incorporou e construiu ao longo de sua trajetória, traduzido em processos formativos, se constituem em um habitus que, segundo Bourdieu (1983), é um sistema de disposição durável e transferível que funciona como uma matriz de percepções, apreciações e ações dos atores em diversos espaços sociais. Através de um painel de significações, construído desde a educação familiar primária, constantemente reposto, reatualizado e modificado ao longo da trajetória social do ator, este constrói paulatinamente seu habitus. Através de seus habitus, os atores dão sentido a um campo, conferindo valor às atividades nele desenvolvidas, ou seja, é uma forma de o professor ser, pensar e agir no mundo e em sua prática profissional. Nessa perspectiva, o conceito de formação identifica-se com a ideia de percurso, processo, trajetória de vida pessoal e profissional. Por isso, a formação não se conclui; ela é permanente.

Os estudos de Bourdieu (ibidem) dirigem-se fundamentalmente para os mecanismos de funcionamento de diversos espaços sociais, denominados 'campos', que são espaços estruturados de posições definidoras, de propriedades e estratégias de ações específicas, assim como objetos de disputas e interesses próprios. Pelo estudo da identidade dos docentes das IES privadas, procuro pistas para a análise do campo do ensino superior particular, em especial nos cursos de licenciatura.

A atuação dos atores em um determinado campo se dá pela influência do que Bourdieu chama de habitus. O conceito de habitus é um instrumento teórico e metodológico criado por este sociólogo francês para discutir a relação entre indivíduo e sociedade. É na relação entre habitus e campo, com a posse de determinados capitais (econômico, cultural, simbólico ou social), que se constrói o motor da ação na perspectiva teórica de Bourdieu. $O$ autor reconhece o indivíduo como portador de estratégias de ação, analisando-o como um agente socializado. É pensando o ator como um indivíduo socializado, representado pela constituição de 
um habitus, que Bourdieu busca uma mediação reflexiva para a discussão da relação entre indivíduo e sociedade, ou mais especificamente entre ator e instituição.

O habitus contribui para a constituição de um determinado campo ao produzir agentes que dão sentido às atividades nele desenvolvidas. A relação que um indivíduo mantém com sua cultura, ou mais especificamente com seu campo, depende das condições nas quais ele a adquiriu. Através do estudo do habitus dos docentes dos cursos de licenciatura de IES privadas, podemos melhor compreender a relação que eles mantêm com o campo do ensino superior. Isso pode ser possível por intermédio da análise das trajetórias profissionais desses docentes. Assim, pude conhecer características de origem familiar e educacional, posição econômica, enfim, elementos que situem os docentes na estrutura social. Dessa forma, acredito também ser possível buscar aspectos que possam construir uma análise dos valores hegemônicos presentes na estruturação do campo do ensino superior privado, e o que cada docente tem de específico.

Compreender a profissionalidade do docente de ensino superior requer dar-se conta dos espaços em que ele está inserido, além do cotidiano, e as articulações que demandam como resultado desse processo, tais como: planejamento de aula, organização de currículos e programas, metodologia desenvolvida em sala de aula, relação professor/aluno e avaliações.

\subsection{A profissionalização em questão}

O conceito de "profissionalidade" docente nesta pesquisa é entendido a partir de Giméno Sacristán (1995), mesmo que nos seus estudos ele refira-se a professores da escola básica. Sua tese principal relaciona-se com a necessidade de se desenvolver a

[...] profissionalidade dos professores no contexto de uma maior qualidade do ensino, a partir da compreensão das práticas docentes nas suas mais diversas configurações. Define como profissionalidade como sendo a afirmação do que é específico na ação docente, isto é, o conjunto de comportamentos, conhecimentos, destrezas, atitudes e valores que constituem a especificidade de ser professor. (1995, p. 65).

Outra influência para o entendimento a respeito da categoria profissionalismo é a reflexão de Popkewitz (1997, p. 125-126), para quem "a retórica (tanto dos liberais como dos conservadores) sobre profissionalismo defende uma maior 
responsabilidade e autonomia do professor e visa criar valores de apoio e criatividade individual, à flexibilidade e ao raciocínio crítico". De acordo com o autor, a profissionalidade docente está em permanente elaboração, devendo ser analisada em função do momento histórico em que se dão as relações sociais.

Popkewitz (ibidem) afirma que o conhecimento da prática pedagógica, bem como qualquer possibilidade de alterá-la, vai depender da compreensão que tivermos das interações geradas em três diferentes contextos, quais sejam:

1) $O$ contexto propriamente pedagógico, formado pelas práticas cotidianas derivadas da atividade de ensinar, tais como: as rotinas de classe, os procedimentos que norteiam as aulas, tudo o que chamamos de prática. Esse contexto diz respeito às funções do professor em sua atividade de docência.

2) O contexto profissional dos professores, que como grupo elabora modelos de comportamento profissional (ideologias, conhecimentos, crenças, visões de mundo etc.), produzindo um saber técnico que legitima suas práticas.

3) O contexto sociocultural, que proporciona valores e conteúdos considerados importantes e valiosos. Nesse aspecto, no ensino superior, entra um componente importante, que é a valorização de determinadas profissões em detrimento de outras.

Poderíamos dizer que a profissionalidade seria a profissão em estado de ação. Assim, pode ser compreendida como a expressão da especificidade da atuação dos professores na prática, isto é, a partir do conjunto de atuações, conhecimentos, atitudes, valores ligados a ela e que constituem o específico de ser professor. Como cita Giméno Sacristán (1995, p. 67), “educar e ensinar é, sobretudo, permitir um contato com a cultura, na acepção mais geral do termo; tratase de um processo em que a própria experiência cultural do professor é determinante".

Então, compreender a profissionalidade do docente de ensino superior requer abarcar os espaços em que ele está inserido, além do cotidiano, e as articulações que demandam como resultado desse processo, como: planejamento de aula, organização de currículos e programas, metodologia desenvolvida em sala de aula, relação professor-aluno e avaliações. 
Zabalza (2004), no seu livro O ensino universitário: seu cenário e seus protagonistas, falando a partir de uma perspectiva europeia, o que ele denomina de "grandes desafios da formação dos professores universitários" (p.59), chama a atenção para as mudanças por que as universidades estão passando na contemporaneidade e como isso se reflete na atividade docente. Neste estudo refere-se à necessidade de reforma no cenário universitário. Esse lócus envolve a instituição no que diz respeito aos conteúdos, ao corpo docente e discente e à instituição como um todo. Tais necessidades de mudanças no ensino superior configuram-se na ação ativa dos movimentos sociais e nas consequentes transformações por ela provocadas. Pontuam-se os movimentos porque são minorias organizadas e desejosas de uma vida digna, na busca do bem-estar e do conhecimento referendado às exigências do mercado de trabalho contemporâneo. Sendo esses movimentos também gênese de lutas e conquistas na história da humanidade, a universidade deve estar atenta a essas mudanças e exigências sociais.

Nessas últimas décadas, a preocupação com a formação de professores do ensino superior torna-se um importante objeto de estudos e pesquisas também no Brasil, bem como a qualidade desse ensino. Como refere Cunha (1989, p. 25), "Meu interesse foi partir do desempenho do professor e aprofundar estudos sobre sua história para identificar que influências foram, para ele, mais significativas. Quis analisar o que acontece na prática pedagógica e por que acontece".

A citação acima fornece pistas sobre a importância da análise da história de vida do professor, assim como das influências de outros professores durante a sua trajetória. Os estudos de Batista e Batista contribuem e destacam a importância dos atributos de um professor universitário envolvido diretamente com o trabalho docente, pela voz dos alunos, que diziam:

O docente deve ter domínio do conteúdo da disciplina que leciona e dos
aspectos didático-pedagógicos, a possibilidade de um relacionamento
interpessoal e afetivo com o aluno; compromisso profissional com a
docência; investimento no processo de independência e autonomia
intelectual e assunção de uma postura ético-política diante das ações
acadêmicas. (BATISTA e BATISTA, 2002 p. 189).

Dessa maneira, os autores lembram que, para discutir a formação do professor universitário, é necessário levar em conta as exigências sociais tanto ao profissional formado quanto ao profissional a ser formado, compreendendo em que 
circunstâncias históricas são exigidas as habilidades técnicas articuladas às posturas éticas. Para Batista e Batista, o processo de formação não poderá ser desenvolvido sem que se considerem as determinações sociais, políticas e econômicas de uma dada sociedade. O processo é complexo e múltiplo, concluem, e não pode ser encarado apenas a partir de "uma simples escolha da ênfase a ser dada no pensamento ou na ação, na razão ou na emoção, na relação "eu e os outros", ou "nas relações produtivas da sociedade e seus espaços de reprodução" (BATISTA; BATISTA, 2002, p. 188).

A complexidade do processo está em compreender que todas as dimensões compõem a profissionalidade do professor e que este está em constante formação e exposto às múltiplas contingências do ambiente onde atua.

Essa variedade de autores preocupados com as questões que envolvem a docência de ensino superior, cada um ao seu modo e segundo a sua abordagem, aliada às referências que faço ao longo do texto, embora não sendo exaustivas, serve para explicitar o quanto esse campo de investigação e produção acadêmica vem demandando estudos e reflexões.

\subsection{O professor universitário e sua formação}

Para se discutir a formação do professor universitário, parece necessário que se levem em conta as exigências sociais tanto para o profissional formado quanto para o profissional a ser formado, compreendendo em que circunstâncias históricas são exigidas as habilidades técnicas articuladas às posturas éticas. Diversos estudos ressaltam que o processo de formação não poderá ser desenvolvido sem que se considerem as determinações sociais, políticas e econômicas de uma dada sociedade. Batista e Batista (2002) concordam que o processo é complexo e múltiplo e não pode ser encarado apenas a partir de "uma simples escolha da ênfase a ser dada no pensamento ou na ação, na razão ou na emoção, na relação 'eu e os outros' ou nas relações produtivas da sociedade e seus espaços de reprodução" (p.188).

Como explicitei anteriormente, alguns autores preocupados com questões que envolvem a docência de ensino superior evidenciam o quanto esse campo de investigação e produção acadêmica vem se desenvolvendo. Diversas pesquisas no âmago da universidade, sobre os processos formativos do professor universitário, 
indicam a importância da Pedagogia Universitária. Estudos como os de Cunha (2007a,2007b e 2000) problematizam que a crise da modernidade e o desenvolvimento tecnológico têm mostrado que já não é mais possível a docência do professor universitário se basear na transmissão de conhecimento, nem que sua competência seja balizada pelo grau de erudição que possui, já que outros e complexos saberes atravessam a docência. Teóricos importantes como Morin (2000) e Sousa Santos (2000) têm evidenciado que as mudanças epistemológicas que se gestaram no século $X X$ têm significativos impactos sobre os processos de ensinar $e$ aprender num mundo de crescente complexidade.

Portanto há uma emergência da Pedagogia Universitária, que impõe a necessidade de se discutir como campo científico. Sendo um tema emergente, localizar suas fragilidades de reconhecimento no âmbito acadêmico não basta para atestar sua importância; é preciso compreender as razões dessa fragilidade e assumir (ou não) a necessidade de alcançar um novo estatuto para esse campo do saber (CUNHA, 2007b, p. 7).

Correia (1989) afirma que a universidade, para saber que está em um mundo em constante transformação, precisa acompanhar esse movimento.

Como consequência da insatisfação social, principalmente no que diz respeito ao mercado de trabalho e à qualidade da formação, tenta-se buscar na universidade uma resposta para essa inquietante situação. Com o compromisso legitimado, vindo das representações sociais e das obrigações atribuídas a elas, através do imaginário social, chega o momento de a instituição de ensino superior repensar suas teorias e práticas, tanto na complexidade do cenário quanto nos protagonistas que a compõem.

Lucarelli (2005) aponta para alguns problemas que se apresentam na universidade atualmente, os quais reforçam a exigência da sociedade com relação à formação de profissionais em função de um mercado restrito, e a um Estado que é frágil no seu compromisso com o processo de formação. Concordando com a autora, percebo que os desafios de uma sociedade de consumo e de novas tecnologias de informação têm influência no ensino superior. Entretanto, se o investimento nas tecnologias é importante para a compreensão do mundo digital, os desafios para a universidade na era da complexidade extrapolam essa perspectiva e não se pode ter uma visão reducionista de mudança e inovação apenas nessa direção. 
Para tal, Oliveira et al. (2003) ressaltam o quanto é importante a reflexão a respeito de quem é o professor universitário e como tem produzido sua profissionalização, indicando para a concepção de que a docência incorpora conhecimentos desenvolvidos em diferentes áreas. É necessário conhecer os saberes construídos na trajetória docente do formador: práticas, teorias, atitudes e experiências vindas, talvez, de espaços coletivos.

$\mathrm{Na}$ perspectiva do ambiente e da formação universitária, presenciam-se mudanças no cenário formativo universitário nesta última década, incluindo a massificação pelo acesso das camadas sociais no ensino superior e um número maior de vagas. Dá-se um novo sentido à formação continuada, à expansão de instituições de ensino superior, incluindo a exigência da construção coletiva do conhecimento. Essas são algumas mudanças no cenário formativo universitário que se instauram como desafio à formação.

No que tange aos aspectos culturais e sociais, percebe-se a necessidade de se criar sistemas de formação que considerem as especificidades regionais, não perdendo de vista o novo cenário, que é globalizado, interinstitucional. Nesse sentido, o ensino universitário reflete essas exigências complexas da sociedade. De acordo com Zabalza (2004, p. 36),

[...] a formação é cada vez mais necessária e profunda à medida que as atividades (profissionais, sociais e, inclusive, pessoais) tornam suas exigências mais complexas. Por isso há muitas denominações dadas a esse momento histórico: sociedade da aprendizagem, sociedade da formação, formação contínua, etc. Essa presença universal do aspecto formativo e sua incorporação à dinâmica do dia a dia da vida das pessoas trouxeram consigo efeitos relevantes.

O ensino universitário depara-se com a necessidade de que o professor remeta seus discentes a uma experiência desafiadora, produtiva e conectada à realidade. Essas experiências podem ser prazerosas e empíricas desde os primeiros semestres da graduação. No decorrer da ação formadora, incorporou-se a ideia de que a educação superior se encaminha para o planejamento da vida. Mas a grande valia da formação está no processo de crescimento e de aperfeiçoamento dos seres como pessoas, possibilitando que os sujeitos utilizem suas habilidades cotidianas e enriqueçam suas experiências vitais.

Nesse sentido, as experiências desafiadoras podem desencadear um processo inovador. Para que seja possível, é necessário superar práticas repetitivas, ir além do ensinar na lógica da reprodução. É preciso incentivar a pesquisa, de 
forma que os formadores possam e saibam utilizar diferentes fontes de informação/formação, compreendendo-as como processo da aprendizagem em que professor e aluno são aprendentes, atores no ato educativo de ensinar, levando em conta as diversidades de cada um e as experiências já vividas em momentos outros. As inovações pedagógicas vão se construindo à medida que os professores estão constituindo sua profissionalidade, a partir das inquietações, das necessidades e da imaginação.

Estudos recentes possibilitam assinalar o processo de mudança na profissão. As leituras, discutidas coletivamente, viabilizam o processo de troca e, consequentemente, acontece a construção coletiva de novos conhecimentos que podem refletir na formação dos professores.

O ensino universitário está em constante mudança, porque assim está a sociedade. É necessário que o professor seja reflexivo nesse contexto de prática, problematizador e pesquisador em seu próprio campo de atuação para acompanhar a gama de exigências que essas mudanças conclamam. O professor, sendo autônomo e crítico, constrói conhecimentos confluentes com essas mudanças, configurando uma universidade consolidada às bases do conhecimento, podendo apresentar um comprometimento maior com o desenvolvimento integral do sujeito e com o desenvolvimento da sociedade.

Ao fazer menção ao professor universitário, Nóvoa (2011) afirma que para melhor se conhecer a singularidade do professor é producente transitar pelas dimensões que definem a ação do professor. A 'dimensão pessoal' ressalta os aspectos particulares, como: ciclo de vida, vivendo a autoestima na construção de sua identidade, conseguindo se reportar aos enquadres das exigências sociais da época, ressaltando relações interpessoais, demonstrando segurança ou não na carreira docente, estando aberto para a inovação, apresentando satisfação profissional que demonstre otimização e compromisso à instituição ou não.

A 'dimensão profissional' apresenta a necessidade de formação docente: direitos e deveres significativos como trabalhador da instituição; a capacidade de adaptação do tradicional ao novo; programas de acompanhamento à docência que interliguem os interesses da instituição com os do professor. Conta, também, com instrumentos que viabilizem reflexão sobre a prática. É necessário pesquisar ainda sobre o professor universitário porque, através da investigação, é possível construir novas representações para esses profissionais, pois, na complexidade pós- 
moderna, a docência implica desafios e exigências vinculadas ao conhecimento. $\mathrm{O}$ professor necessita de competências, comunicabilidade, metodologias favoráveis à produção desse conhecimento.

Entretanto é preciso refletir e propor alternativas para o docente universitário que potencializem seus saberes já construídos e que valorizem sua experiência. Trata-se de pôr em marcha uma pedagogia dialógica entre o campo específico e o campo pedagógico para dar sentido à formação. Nessa perspectiva, também a formação do professor universitário tem de se reinventar, afastar-se das prescrições e encontrar alternativas para potencializar os significados que os professores atribuem ao seu fazer profissional. 


\section{A DOCÊNCIA E A APRENDIZAGEM NAS LICENCIATURAS}

Historicamente, a formação inicial de professores no Brasil tem similaridade com outros países, com predominância de dois modelos principais denominados racionalidade técnica e racionalidade prática. Schön (1992) referindo-se ao primeiro modelo de formação de professores como ideia de acúmulo de conhecimentos teóricos para posterior aplicação. Nele, a formação de professor está pautada na dicotomia teoria e prática, privilegiando o conhecimento teórico em detrimento do conhecimento pedagógico e prático.

Os estudos atuais têm proposto a defesa do modelo da racionalidade prática, inspirados nas ideias de valorização da prática no desenvolvimento da construção dos saberes referentes à profissão docente. Nesse sentido, a prática docente é concebida como um processo de investigação na ação. O processo de formação do professor, ao contrário do que sugeria o modelo da racionalidade técnica, tem uma perspectiva de trajetória e é visto como desenvolvimento profissional.

As reflexões sobre a formação de professores começaram a ganhar estatuto de conhecimento científico na medida em que a educação, com base nas ciências sociais, reivindicou para si essa legitimidade. Decorrente da perspectiva dominante de ciência, os estudos iniciais desenvolvidos no campo educativo incorporaram os pressupostos da ciência moderna. O olhar sobre a formação de professores apontava para a construção de modelos prescritivos de perfis que pudessem alcançar generalizações capazes de melhor informar a respeito dessa tarefa. As pesquisas enfatizavam as competências necessárias ao professor a partir de um construto idealizado. Suas condições objetivas de vida, formação e trabalho não se constituíam como um pressuposto da sua docência.

Cunha (2001, p. 2) lembra:

\footnotetext{
Foram as chamadas teorias críticas, em forte expansão no mundo ocidental que, ao final dos anos setenta, interferiram nas percepções dominantes de formação de professores realizada no espaço acadêmico e escolar. $O$ reconhecimento da educação como uma produção histórica e socialmente produzida estabeleceu-se como um pressuposto necessário ao entendimento da docência. Estudá-la pressupunha tomar o professor na sua condição concreta de vida, marcada por uma trajetória cultural e contextual. Não mais se poderiam propor modelos universais e generalizáveis para a formação de professores, pois, apesar da identificação de componentes comuns presentes na base da profissão docente, as circunstâncias de sua produção se configurariam singularmente.
} 
A reflexão sobre a formação de professores é subsidiária das compreensões políticas da educação. As posturas filosóficas e epistemológicas que sustentam essas compreensões têm relação direta com as propostas de formação. Essa referência tem favorecido os estudos que recuperam os processos formativos na sua constituição histórica, ligando-os a tendências paradigmáticas que revelam em seus perfis.

\subsection{Os cursos de licenciatura na legislação brasileira}

Os cursos de licenciatura no Brasil vêm sofrendo alterações substantivas que culminaram com a Lei n 9.394/96 (Lei de Diretrizes e Bases da Educação Nacional). Krahe (2004) aponta que essa legislação trouxe indicações inovadoras no que tange à formação de professores nesta virada de milênio. O conjunto das Diretrizes Curriculares para Formação de Professores - DCN (BRASIL, 2001) procurou romper com o modelo tecnicista, seguindo uma filosofia de formação que enfatiza a compreensão de que o professor não possua somente conhecimentos superficiais com relação ao seu trabalho, e que não se limite em transmitir conhecimentos prontos e acabados, mas que possa contribuir para uma prática reflexiva de ensino.

As DCN, que servem de parâmetro para a estruturação de cursos, trazem em seu cerne a noção de competência. Ao mesmo tempo, contudo, propõem alternativas com vistas às competências processuais mais amplas, que possibilitem reorganizações inovadoras. A pesquisa aparece como uma possibilidade de articulação da teoria-prática. É proposto às instituições que adotem práticas pedagógicas na interface graduação/pós-graduação com estímulo à pesquisa e à inserção na comunidade via extensão, vinculadas à lógica das competências, de autonomia, flexibilidade, adaptabilidade e descentralização.

O Conselho Nacional de Educação (CNE), através da Resolução n 1/2002, em seu artigo terceiro, estabelece que todos os professores, para atuar na educação básica, devem ser formados tendo os seguintes princípios norteadores:

I - a competência como concepção nuclear na orientação do curso;

II - a coerência entre a formação oferecida e a prática esperada do professor, tendo em vista:

a) A simetria invertida, onde o preparo do professor, por ocorrer em lugar similar àquele em que vai atuar, demanda consistência entre o que faz na formação e o que dele se espera. 
b) A aprendizagem como processo de construção de conhecimentos, habilidades e valores em interação com a realidade e com os demais indivíduos, no qual são colocadas em uso capacidades pessoais.

c) Os conteúdos, como meio e suporte para a constituição das competências.

d) A avaliação como parte integrante do processo de formação, que possibilita o diagnóstico de lacunas e aferição dos resultados alcançados, consideradas as competências a serem constituídas e a identificação das mudanças de percurso eventualmente necessárias.

III - a pesquisa, com foco no processo de ensino e de aprendizagem, uma vez que ensinar requer tanto dispor de conhecimentos e mobilizá-los para a ação, como compreender o processo de construção do conhecimento.

Desse modo, não é suficiente o professor conhecer bem o conteúdo ou ser um bom pesquisador de sua área. Ele precisa conhecer seu auditório - na expressão de Boaventura de Sousa Santos (2002), para designar as pessoas com as quais vai manter relações de formação - e saber trabalhar com esse conhecimento de acordo com a realidade que o cerca, com os interesses desse auditório. O que se espera é um professor polivalente e flexível, que esteja centrado na capacidade de adaptação e de soluções, que se renova em provimento às rápidas mudanças sociais.

Novos parâmetros para a profissionalização docente, em que a identidade se teça na competência e no compromisso, são urgentes: o professor precisa ser reconhecido pessoal e profissionalmente, sendo ele um importante eixo central das atividades de formação de seus estudantes.

\subsection{A docência e a aprendizagem nas licenciaturas}

A práxis educativa é condição para a mediação da cultura, e é na linguagem que os sujeitos se constroem, desde que a discutibilidade entre eles seja pública e socializável. Analisando a sala de aula, pode-se perceber que é um espaço repleto de signos e significações que tomam forma e cor através da linguagem. Através do diálogo entre professor e aluno, interagindo com o mundo e produzindo cultura é que a aprendizagem se concretiza. Ela se dá pela articulação entre o mundo vivido, o qual se entende como um lugar transcendental em que o falante e o ouvinte se encontram; é o lugar em que podem estabelecer reciprocamente a pretensão de que suas visões concordam com o mundo objetivo, subjetivo e social, e em que podem criticar e exibir os fundamentos das respectivas pretensões de validade, resolver seus desentendimentos e chegar a um acordo. É no sistema social que o ser 
humano se constrói, que o professor se transforma em mediador da discutibilidade emancipatória na ação educativa.

$\mathrm{Na}$ tarefa de ensinar, não há como desconsiderar que, na sua essência, inclua também o aprender, sendo ambos elementos básicos e fundamentais do trabalho docente: não se ensina o que não sabe e, sabendo, é também preciso aprender.

Encontra-se em Freire (1996) que não há docência sem discência. Ambas se explicam em que seus sujeitos, apesar das diferenças que os conotam, não se reduzem à condição de objeto um do outro. Diz o autor que quem ensina aprende ao ensinar e quem aprende ensina ao aprender, caracterizando processos de interação humana, base da atividade educativa.

Nesse sentido, Habermas (2000) destaca que a educação, desde sempre, se inscreveu sob os télos de diálogo, um processo interativo em que a constituição do sujeito se dá pela ação comunicativa entre os homens.

O docente de ensino superior tem no processo de ensino-aprendizagem um dos focos principais de sua atividade. E, para lidar com a diversidade de indivíduos que constituem o público universitário, terá de possuir a capacidade comunicativa de estabelecer o diálogo com seus estudantes.

No caso das licenciaturas, essa condição se torna mais emergente, pois nesse espaço de aprendizagem o conteúdo é forma. O fazer do professor com os seus alunos estabelece a referência da prática pedagógica, que é o conteúdo que o professor quer ensinar. Portanto o agir do professor é duplamente responsável pelo aprendizado do estudante: pelo que ele diz e pelo que ele faz; 'o que professa'. Por essa razão, a prática dos docentes no campo da Didática, incluindo as Didáticas Específicas, merece estudos especiais.

É importante por isso compreender a Didática e as Didáticas Específicas como um campo fundamental na formação profissional dos professores. Procuram elas instrumentalizar na perspectiva teórica e prática a atuação dos docentes na escola e na aula. Envolvem as matérias de estudo e os instrumentos do trabalho do professor, incluindo as relações entre o ensino e a aprendizagem e os conteúdos específicos do currículo escolar. Espera-se que a didática faça a mediação cultural e cognitiva entre as estruturas do estudante e os objetos do conhecimento, razão pela qual o conceito nuclear do didático é a aprendizagem, que por sua vez é a razão do ensino (LIBÂNEO, 2010). 
Se o núcleo da didática é o conhecimento científico dos processos de transmissão e apropriação de conhecimentos (ensino e aprendizagem) de um conteúdo disciplinar, é impossível desvinculá-lo da epistemologia, ou seja, da natureza do conhecimento, sua gênese e sua estrutura; ao mesmo tempo, se o ensino se dirige à aprendizagem dos alunos, o saber científico precisa converter-se em saber a ser ensinado pelo que a ciência precisa passar por uma transposição didática. (LIBÂNEO, 2010, p. 86).

Ao concordar com o autor, compreendo que os professores, em especial os de disciplinas de Didática e Didáticas Específicas dos cursos de licenciatura, pela apropriação dos modos de ação e das compreensões epistemológicas que sustentam as suas metodologias, ensinam seus estudantes a serem professores no ensino fundamental. Suas práticas revelam concepções e saberes e por elas expressam sua profissionalidade.

Entretanto Libâneo (2011) reforça ainda que não basta o professor dominar o conteúdo, ele precisa dominar também os processos investigativos da disciplina, as ações mentais, os procedimentos lógicos de estudo da disciplina, pois, na concepção atual da aprendizagem, aprender implica a relação do aluno com os objetos de saber. E esse é o sentido do ensinar com pesquisa.

A aprendizagem acontece entre as dimensões básicas interpessoais e na relação com a eficácia de cada um no processo de aprender. Cada vez mais se valoriza a capacidade de as pessoas estarem em relações favoráveis umas com as outras, pois os sujeitos, na interação de ser aprendente e assimilar conhecimento em cada nova aquisição, vão se construindo e se formando. Por essa razão, as questões que permeiam o processo ensino-aprendizagem na sociedade contemporânea exigem mudanças substantivas no modo de ensinar na universidade.

Nesse sentido, para Candau (1988), o grande desafio do professor de Didática - geral ou específica - é superar o formalismo didático, ou seja, a busca de um método único capaz de ensinar tudo a todos. Também é imprescindível superar a visão reducionista, pois o método didático tem diferentes estruturantes - entre eles o conteúdo -, e o importante é articular esses diferentes estruturantes na tentativa de superar as dicotomias no processo de ensino e aprendizagem.

Zabalza (2004) acredita em um discente ativo, participativo, conhecedor das necessidades e com disposição para atender às demandas da sociedade. Propõe a metáfora de que aprender é como conversar, em que esse diálogo conclama o envolvimento da universidade com a sociedade. Na dúvida, no questionamento 
conflitante, na ação reflexiva, no planejamento e nas avaliações coletivas, em nível macrossocial/educacional, pode-se procurar inspiração para as reformas curriculares e metodológicas necessárias ao ensino superior e em especial na formação de professores.

Estudos vêm sendo realizados na expectativa de avançar em alternativas que venham ao encontro dessas condições. Para Imberón (1994, p. 65),

[...] a inovação na prática se dá quando a pessoa que executa reflete e interioriza o processo como próprio, extrai conclusões sólidas, planeja a ação e é capaz de levá-la a cabo estabelecendo elementos de nova reflexão e inovação.

Esses estudos parecem indicar um novo olhar sobre o processo educativo e apresentam situações em que o aluno aparece como atuante de sua própria formação.

Para Cunha (1998, p. 20), "inovações que procuram explorar novas alternativas que, muitas vezes, se constroem na contramão das forças dominantes, podem ser importantes marcos para a construção de novas possibilidades" no ensino superior. A autora afirma, ainda, que "as repercussões desse processo evolutivo de pensar o conhecimento e de reorganizar as ciências estão trazendo profundas alterações no mundo contemporâneo e, consequentemente, para a universidade".

Na tentativa de sinalizar indicativos para a compreensão do significado de experiências inovadoras, Cunha (2000) menciona critérios como: romper com o tradicional e transitar na importância do subjetivo; promover, através da formação, sujeitos construtores de si e da sociedade; romper com as dualidades ciência/significações, saber popular/saber científico e educação/trabalho; relacionar com eficácia teoria/prática; valorizar a criatividade, o questionamento exigente e a incerteza; perceber o conhecimento de forma interdisciplinar, atribuindo relações entre os conteúdos, não perdendo a significação específica de cada um; reflexão e abertura para a inovação. A inovação assume compromisso com aprendizagem, promoção da justiça e da liberdade social.

Uma Didática que incorpore os princípios da ruptura paradigmática semelhantes aos que aqui foram explicitados ao discutir o conceito de inovação pode encaminhar, na formação dos estudantes dos cursos de licenciatura, uma perspectiva metodológica na mesma direção. Seria uma Didática em ação, 
protagonizada pelo professor formador que, por sua prática com seus estudantes, estaria vivenciando o conteúdo da própria Didática.

Essas situações requerem uma profissionalidade que exige ruptura com o tradicional e, ao mesmo tempo, reflexão profunda em sua prática. Para que o professor construa sua profissionalidade, ele busca os saberes da prática e da teoria. Os saberes da prática são cada vez mais considerados como relevantes no processo de aprendizagem, tanto na formação de professores quanto para os alunos. Ele certamente carrega uma experiência construída anteriormente, e o novo é incorporado a estruturas já existentes.

Quando o professor se defronta com uma proposta de mudança, provavelmente sofre uma desestabilização em suas práticas e crenças, pois o novo provoca conflitos. A mudança introduz-se em um espaço dialético, no qual o professor avalia sua utilidade e o grau de esforço que lhe é exigido. A inovação é submetida ao seu exercício prático.

Sousa Santos (1994, p. 34) afirma que "quanto mais global for o problema, mais locais e mais multiplamente locais devem ser as soluções". Por isso, de acordo com Cunha (2000, p. 145),

[...] investigar experiências inovadoras localizadas, que tenham indícios de processos rupturantes, pode ser uma interessante alternativa para a melhoria do processo educativo. Temos o intuito de, assim fazendo, poder contribuir para que a universidade e os sistemas educativos sejam uma alternativa a eles próprios. Será este intento um mito ou uma possibilidade?

Na concepção de Paulo Freire (1996), a educação sozinha não pode mudar o viés social, mas certamente a sociedade conecta-se às mudanças da educação para marcar sua mobilidade. As instituições precisam aprender a adaptar-se às exigências da sociedade vigente e podem criar novas linhas de atuação para atender a essas exigências. O aprender começa no momento do reconhecer-se como instituição que ensina e que também aprende.

Em se tratando de construção da competência, a especialização e o comprometimento com a formação acadêmica são essenciais para o professor das licenciaturas. A construção do conhecimento pedagógico, envolvendo trocas de saberes nesse processo pedagógico coletivo, abre frestas à reflexão teórica e empírica da docência. A inovação na formação do formador pode dar outro rumo à sociedade, porque pode impactar a formação de seus estudantes. 
Lucarelli (2000) sugere que a inovação universitária pressupõe metodologias que rompem com as didáticas vigentes no tocante aos conteúdos, às estratégias, aos recursos, aos propósitos, incluindo as relações entre instituição/alunos/ professores. Outro ponto relevante, de acordo com a autora, está relacionado com a superação da fragmentação em disciplinas, fazer formação através da metodologia de projetos e o desapego ao conhecimento voltado ao tecnicismo. Assim, é relevante pensar a pesquisa versando sobre eixos temáticos articuladores e a interdisciplinaridade no ensino universitário.

Também são de Lucarelli (ibidem) as afirmações de que há a necessidade de criar espaços para a problematização e a mobilização de teorias e práticas. A articulação empírica e teórica, tanto como processo genuíno de aprendizagem quanto na aquisição de habilidades complexas da profissão, é elemento significativo como dinamizador de processos constituintes da didática universitária. A autora afirma que, desde a década de 1970, a universidade vem pensando em linhas de investigação que abordam inovações, com o intuito de enfrentar a crise do ensino. Nessa perspectiva, a relação entre teoria e prática pode constituir um importante dispositivo metodológico de ensino-aprendizagem, em âmbito de universidade.

Várias são as reflexões acerca do ensino superior e do campo da Didática remetidas ao cenário e aos protagonistas, propondo mudanças paradigmáticas inovadoras, tanto nos currículos de cursos quanto na formação de formadores.

Atitudes emancipatórias também exigem conhecimentos acadêmicos e
competências técnicas e sociais que configurem um saber fazer que
extrapole os processos de reprodução. Entretanto, não se estabelecem
sobre um ethos regulatório geral. Ao contrário, como afirma Sousa Santos
(2000), sua característica é de não ser indiferente à diferença (p. 30). Isso
significa que a competência situa-se justamente em agir diferenciadamente
para cada situação, a partir da leitura da cultura e das condições de
produção do conhecimento que se estabelece entre o professor e seus
estudantes. (CUNHA, 2005, p. 8).

É importante mencionar que os indicativos da competitividade e da produção, em um território contornado pela globalização, acenam a uma educação mais exigente para os formadores. A formação destes deve estar comprometida com a profissão dos discentes como ativa, desafiadora e produtiva para a realidade do mercado econômico-social.

Se essas condições são importantes para todos os docentes de educação superior, mais se instituem para os que formam professores, em especial aos que atuam nas disciplinas pedagógicas, no campo da Didática e das Didáticas 
Específicas. Para estes, conteúdo é forma; precisam estar atentos para a coerência entre o que anunciam e o que vivenciam. 


\title{
5 CAMINHOS PERCORRIDOS: A TRILHA DA PESQUISA
}

\author{
Ninguém caminha sem aprender a caminhar, sem aprender a fazer o \\ caminho caminhando, refazendo e retocando o sonho pelo qual se pôs a \\ caminhar. (FREIRE, 1996, p.35).
}

Para melhor compreender o processo de ensino-aprendizagem no espaço universitário, foi necessário me inserir no cotidiano das práticas e buscar entender a multiplicidade de fatores presentes nessa realidade tão complexa. Acompanhar as aulas, as histórias que somente os protagonistas poderiam me contar foi de grande relevância para o conhecimento e a reflexão sobre a universidade, seus alunos e as alternativas de práticas que se instituem nesses espaços.

Neste capítulo, apresento o caminho da investigação de forma detalhada, explicitando como foi realizada a pesquisa, em termos das estratégias e opções metodológicas utilizadas na investigação, bem como os procedimentos de coleta e análise dos dados.

\subsection{Um pouco da história da instituição pesquisada}

Utilizo para realizar a escrita deste breve histórico os próprios Projetos Pedagógicos dos Cursos (PPC) e o site oficial da instituição pesquisada. É considerada multicampi, confessional e comunitária, dedicada à produção, à preservação e à divulgação do conhecimento, reconhecida pelo Ministério de Educação mediante a Portaria $n^{\circ} 681 / 89$, tem sede e foro em Canoas-RS. É mantida pela Comunidade Evangélica Luterana São Paulo (CELSP), pessoa jurídica de direito privado, sem fins lucrativos, com sede e foro em Canoas, que congrega escolas de educação básica e estabelecimentos de ensino superior.

Com o desenvolvimento do município de Canoas, que hoje é o polo de uma das mais importantes áreas econômicas e industriais do Rio Grande do Sul, cresceu a necessidade de expansão da rede de ensino em todos os níveis. Em 1968, foi criada a escola profissionalizante de Ensino Fundamental e Médio, oferecendo então os cursos Ginasial e Técnico em Secretariado.

Com a demanda crescente por educação superior, em 1972 passou a funcionar, nas dependências desse colégio, o curso de Administração de Empresas. Novos cursos resultaram na criação das Faculdades Canoenses (1977) que, com o 
crescimento, transferiram-se, em 1981, para campus próprio, que hoje é a sede da instituição pesquisada em Canoas, a qual atingiu em 1988 o status de universidade. Possui campi em nove municípios do estado - Canoas, Cachoeira do Sul, Carazinho, Gravataí, Guaíba, Porto Alegre, São Jerônimo, Santa Maria e Torres -, atendendo mais de 34 mil alunos nos seus diversos cursos de graduação na modalidade presencial e mais de 14 mil alunos na modalidade a distância. Acrescentem-se os alunos matriculados em cursos de pós-graduação lato sensu, nas modalidades presencial e a distância, e os cursos de stricto sensu (sete mestrados e três doutorados). Atualmente, milhares de alunos distribuídos em cursos de graduação, extensão e especialização a distância e nas disciplinas dos cursos presenciais que são ofertadas através dessa modalidade comprovam o compromisso de qualidade da instituição perante as demandas da sociedade. Os campi da universidade localizam-se em regiões estratégicas do estado e representam vetores de modificação e de difusão de conhecimento nesses locais. Também possui unidades em outros estados do país: Porto Velho-RO, Ji-ParanáRO, Manaus-AM, Santarém-PA, Palmas-TO, Itumbiara-GO.

A Região Sul possui 27,3 milhões de habitantes, sendo a quarta mais populosa do Brasil, é superada apenas pelas regiões metropolitanas de São Paulo, Rio de Janeiro e Belo Horizonte, respectivamente, e com o quarto maior PIB do Brasil (INSTITUTO BRASILEIRO DE GEOGRAFIA E ESTATÍSTICA, 2010). Canoas, com 324.025 habitantes, possui inúmeras indústrias e é um polo de ensino, contando com cinco instituições de ensino superior ${ }^{4}$

A ampliação da região metropolitana e o consequente deslocamento de centros geradores de emprego coloca Canoas em um ponto estratégico para suprir as demandas dessa região, tanto em termos educacionais, quanto na formação profissional.

A arquitetura dos prédios da instituição investigada é padronizada. Os edifícios possuem em média dois andares, são de tijolos à vista, com boa conservação. São dispostos enfileirados um ao lado do outro. Possuem comunicação entre eles, que é realizada por um longo corredor, onde são oferecidos serviços diversos, lanchonetes, copiadoras, livraria, entre outros. Entre eles, os

\footnotetext{
${ }^{4}$ Disponível em: <http://emec.mec.gov.br>. Acesso em: 13 dez. 2013.
} 
espaços são amplos e cercados por árvores frondosas, que propiciam melhor convivência.

Os prédios distribuem internamente 72 cursos presenciais, 17 cursos EAD e sete semipresenciais, que são oferecidos na instituição. Na maioria deles há um grande saguão, que é utilizado como espaço de convivência. No centro estão localizadas as salas de coordenações e de professores. Nas laterais estão localizadas as salas de aula, as quais são de tamanhos variados e compatíveis com o número de alunos, possuem classes e cadeiras, quadro branco, janelas amplas para permitir a entrada de luminosidade natural e ventilação de maneira geral.

\subsection{Procedimentos e questões norteadoras}

A epígrafe que dá início a este capítulo inspira a compreensão de que também o caminho da pesquisa não é linear e que buscar essa trilha nos possibilita desvendar o objeto de estudo de forma eficiente, para atender o nosso problema de estudo. Constituiu-se numa tarefa íngreme, mas prazerosa.

O intuito desta pesquisa foi compreender os modos de produzir e interpretar a prática docente, buscando entender o que leva cada professor a agir de uma determinada forma e não de outra, bem como a relação entre o seu discurso e sua prática em sala de aula. E ainda como os processos de ensino-aprendizagem que o professor protagoniza repercutem na profissionalidade dos alunos, em especial nos cursos de licenciatura, foco deste estudo.

Para isso, foi necessário conhecer não só a dimensão epistêmica do processo de ensinar e aprender, mas também as tramas de relações que configuram a sua dimensão didático-pedagógica. Nesse aspecto, estreitaram-se as fronteiras entre o mundo da aula e o que os professores pensam e dizem das suas aulas.

Colocar em pauta a aula universitária e os diferentes modos de pensar a relação ensino-aprendizagem no contexto atual foi muito instigante. Analisar as práticas e o pensamento do docente como organizadores explicitadores da didática que utilizam, bem como dos modos e interações pedagógicas no interior de uma universidade privada e confessional, se constitui num importante exercício.

O estudo da prática pedagógica de docentes universitários induz ao questionamento das contribuições e implicações para o processo de ensino e aprendizagem dos estudantes do ensino superior e sua formação profissional. $O$ 
intuito, nesta tese, foi também trazer a discussão para a formação do docente universitário e para as tensões vivenciadas nas relações acadêmico-pedagógicas no contexto atual. Situando este trabalho no campo da formação de professores, e recortando para a docência universitária, assinalo o interesse de compreender a prática desses docentes de forma contextualizada.

Desenho a construção do método que orienta a leitura de realidade, bem como as indagações frente ao processo de pesquisa. Destaco o processo metodológico da pesquisa de campo - procedimentos e técnicas (MARCONI; LAKATOS, 2002; MINAYO, 1993,1994,1998 e TRIVIÑOS, 1987) - e os passos da coleta de dados e de análise - passos da análise de conteúdo (BARDIN, 1977).

Outros estudos já se dedicaram a desvendar e compreender a prática de professores considerados positivamente por seus alunos (CUNHA, 1989; PIMENTEL, 1993). Esses estudos, construídos a partir de um referencial etnográfico, evidenciaram que a docência é uma construção permanente e que se constitui a partir de múltiplos contextos e experiências. Essa compreensão vem afetando em especial o campo de formação de professores, atingindo as propostas curriculares dos cursos de licenciatura. Nesse sentido, tem sido importante explorar as trajetórias como estudantes, suas representações sociais e suas expectativas, considerando esses fatores como importantes na formação.

Da mesma forma, compreender o desenvolvimento profissional do professor universitário é o pressuposto para revelar as visões políticas e pedagógicas que interferem na constituição dos seus saberes. Esses docentes, em geral, tornam-se referências para seus estudantes e, mesmo sem uma reflexão sistemática sobre os modelos culturais que ratificam, assumem a responsabilidade de ensinar os futuros professores tendo como referência suas próprias práticas. Se essa premissa é considerada importante, compreender como os docentes universitários que atuam nos cursos de licenciatura constroem suas práticas docentes também passa a ser fundamental.

Essa foi a mobilização principal desta pesquisa. Nesse sentido, delineou-se como problema de estudo: Como a trajetória e as práticas de docentes de didática se constituem e repercutem na formação dos alunos dos cursos de licenciatura?

Como recorte da problematização e tomando o universo dos docentes que atuam nos cursos de licenciatura, meu intuito foi focar aqueles que são responsáveis 
pelas disciplinas pedagógicas, ou seja, mais propriamente, as Didáticas. Esse problema investigativo envolveu uma complexidade que supôs, ao menos, três dimensões orientadoras para o estudo, que provocaram as questões de pesquisa:

$1^{\text {a }}$ Dimensão: Trajetória dos docentes

- Que trajetórias de vida e de formação tiveram os professores que atuam nos cursos de licenciatura?

- Que valores e compreensão pedagógica revelam seus discursos?

- Que fontes de saberes nominam como preponderantes em sua formação?

- Que experiências são mais significativas para definir suas práticas?

$2^{\mathrm{a}}$ Dimensão: Práticas dos docentes

- Que práticas pedagógicas são recorrentes no cotidiano das aulas desses docentes?

- Que habilidades/competências revelam na profissionalidade em ação?

- Como articulam e organizam seu ensino?

- Como tomam decisões sobre os rituais pedagógicos que desenvolvem?

$3^{a}$ Dimensão: Repercussões de práticas: a voz dos estudantes

- Que significados atribuem os estudantes às práticas que vivenciam nas disciplinas pedagógicas de seus cursos?

- O que mais valorizam em sua formação?

- O que destacam como significativo?

- O que gostariam que fosse diferente?

- Que experiências mencionam como fundamentais à sua formação?

- O que ensinam as práticas dos professores das disciplinas pedagógicas?

\subsection{Abordagem metodológica: os instrumentos}

A proposta metodológica esteve respaldada na abordagem qualitativa de pesquisa, que nos últimos anos vem sendo intensamente utilizada como uma estratégia para a compreensão efetiva dos problemas educacionais. 
A pesquisa qualitativa tem suas raízes nas práticas desenvolvidas por antropólogos e, posteriormente, por sociólogos em suas pesquisas sobre a vida em comunidades. Com o passar do tempo, essas pesquisas foram amplamente divulgadas e problematizadas em diferentes áreas, as quais foram percebendo que determinadas informações não podem ser somente quantificadas, e sim interpretadas, analisadas de maneira mais abrangente.

As pesquisas qualitativas pressupõem um contato íntimo do pesquisador com seu 'objeto' de pesquisa, em uma relação constante. Utilizei os princípios da etnografia, como modalidade de investigação, tendo como foco de análise a descrição do real cultural de um grupo que busca extrair os significados que emergem nas mais diferentes situações. As metodologias qualitativas permitem a maior compreensão dos fenômenos e enfatizam suas especificidades em termos de suas formas de produção. A escolha por esse tipo de pesquisa se justifica por permitir a descoberta de significados, sentidos, opiniões, valores, crenças, atitudes e emoções (LUDKE, 1986).

A pesquisa de inspiração etnográfica tem como estratégia a inserção do pesquisador na realidade a ser investigada, na perspectiva de que esse movimento forneça a compreensão dos fenômenos. Creio ter sido importante utilizar elementos da abordagem etnográfica para desenvolver este estudo, envolvendo observação, entrevistas profundas e análise documental.

$\mathrm{O}$ trabalho de campo com os docentes desenvolveu-se em duas etapas. $\mathrm{Na}$ primeira, realizei as observações das aulas dos docentes escolhidos a partir das disciplinas e dos cursos que integram a pesquisa. Em uma segunda etapa, após as observações, foram realizadas as entrevistas semiestruturadas.

A opção pela escolha em desenvolver a pesquisa nessa instituição se deve ao fato de atuar em uma das suas unidades e acreditar que é possível, de alguma maneira, contribuir para a compreensão da prática do docente na formação inicial dos acadêmicos dos cursos de licenciatura. A motivação também foi por identificar que, na maioria das vezes, as pesquisas relacionadas ao ensino superior brasileiro têm priorizado as universidades públicas.

A escolha pelos cursos de Pedagogia e Biologia está relacionada ao fato de considerar a diversidade de áreas de conhecimento, podendo haver diferenças na docência, considerando a cultura do campo epistemológico. 
Os docentes que participaram desta pesquisa foram selecionados a partir dos seguintes critérios: trabalhar com as disciplinas de Didática Geral ou Didática Específicas nos cursos de Pedagogia e Biologia; disponibilidade e acessibilidade para participar da pesquisa; flexibilidade para as observações em sala de aula.

Para coletar os dados que se referem aos docentes universitários e às práticas pedagógicas, utilizei a entrevista semiestruturada. Esta é indicada para buscar informações sobre opinião, concepções, expectativas, percepções sobre objetos ou fatos. Para Minayo (1992) a entrevista semiestruturada deve estar focalizada em um assunto sobre o qual haja um roteiro com perguntas principais, complementadas por outras questões inerentes às circunstâncias momentâneas à entrevista. O autor aponta que esse tipo de entrevista pode fazer emergir informações de forma mais livre, e as respostas não estão condicionadas a uma padronização de alternativas.

O roteiro serviu para coletar informações e também para desencadear o processo de interação com o interlocutor, procurando propiciar um contexto amigável. Esse instrumento teve como vantagem a elasticidade quanto à duração, permitindo uma cobertura mais profunda sobre o tema. Além disso, a interação entre o entrevistador e o entrevistado favoreceu as respostas espontâneas, possibilitando uma maior abertura e proximidade. Permitiu explorar assuntos mais complexos e delicados.

A compreensão das práticas desenvolvidas remeteu à exigência da observação de situações de ensino-aprendizagem, usando registros sistemáticos em diário de campo. Realizei o acompanhamento dos docentes pela observação em, ao menos, quatro situações de aulas. Foram previamente combinadas e desenvolvidas durante os dois últimos semestres de 2013. A observação tem sido uma técnica de coleta de dados que possibilita a obtenção de determinados aspectos da realidade. Essa técnica, além de ver e ouvir, consiste em examinar fatos ou fenômenos em situação real. Na observação, foi importante ter clareza do que procurar e o que era importante de ser estudado. Além disso, valeu reconhecer possíveis equívocos, tentando diminuir prováveis perspectivas sobre os dados recolhidos. Para as observações, não elaborei um roteiro prévio, e cada uma das observações foi registrada em diário de campo. Nesse caderno, realizava as anotações dos movimentos que ocorriam na sala de aula, prestando atenção em todos os detalhes possíveis, com relação ao cotidiano da sala de aula. 
A proposta foi observar os professores das disciplinas de Didática-OTP (Organização do Trabalho Pedagógico) e Didáticas Específicas dos dois cursos. Foram envolvidos três professores de Didática-OTP e três professores de Didáticas Específicas, sendo dois do curso Pedagogia e um do curso de Biologia (única disciplina de Didática Específica).

Solicitei autorização para realizar a coleta de dados na instituição para a direção geral do campus. Foi agendada uma reunião, na qual apresentei os objetivos da pesquisa. Recebi a autorização e logo após foi marcada uma reunião com os coordenadores dos cursos com os quais iria trabalhar, para também apresentar o estudo e solicitar os contatos dos professores, horários e outras informações.

Entrei em contato com os professores e realizei reuniões individuais, para falar sobre a pesquisa e me apresentar, em função dos horários diferentes e da disponibilidade de cada um. Sete docentes foram contatados, quatro aceitaram sem restrições as condições para as observações das aulas e a entrevista; a quinta docente foi resistente inicialmente, mas após a minha apresentação permitiu as observações e a entrevista. No momento da entrevista, foi entregue o TCLE, o qual foi assinado pelos que participaram. Foi exceção uma professora do curso de Biologia, que trabalha a disciplina de Didática Específica do curso, a qual não permitiu a observação, assim como não quis participar da pesquisa, mesmo após solicitação do coordenador do curso. Sendo assim, substituí essa professora e tive que aguardar o segundo semestre de 2013 para observar essa disciplina com outro professor, pois o curso de Biologia possui somente uma disciplina de Didática Específica, sendo oferecida uma turma por semestre.

Acredito ser interessante relatar que dois dos professores investigados possuem uma página virtual da disciplina da qual fui convidada a participar. Essa experiência também serviu como um espaço de coleta de informações.

Com relação à representatividade dos dados, considerando o universo de docentes no ensino superior, confesso que inicialmente não me senti segura com o número de professores que estaria pesquisando, se a quantidade de depoimentos seria significativa, mesmo se tratando de uma pesquisa qualitativa. Porém essa sensação mudou quando encontrei nas pesquisas de Bourdieu questionamentos que faz em relação a esse ponto. 
Todos os membros do mesmo grupo ou da mesma classe são produtos de condições objetivas idênticas. Daí a possibilidade de se exercer na análise da prática social, o efeito da universalização e de particularização, na medida em que eles se homogeneizam, distinguindo-se dos outros. (BOURDIEU, 1973 apud MINAYO, 2000 p. 111).

A afirmativa acima significa que as respostas, mesmo de um pequeno número de sujeitos entrevistados, se envolvidos em condições semelhantes de trabalho, cuja prática e experiência possuem a mesma matriz, podem ser representativas de uma dada realidade. Considero que não se trata de uma preocupação em interrogar um grande número de docentes, mas sim de buscar as suas percepções da realidade através da experiência vivida.

Com o intuito de compreender como os currículos e as disciplinas são constituídos, realizei análise documental dos Projetos Pedagógicos dos dois cursos de licenciatura escolhidos. Também foram analisados os planos de ensino das disciplinas ministradas pelos professores, conteúdos programáticos, materiais didáticos utilizados, assim como os instrumentos de avaliação da aprendizagem. Todos os materiais foram disponibilizados pelos professores, inclusive materiais postados em sítios da internet e redes sociais.

Para melhor compreender o significado dos processos observados em situações de trabalho na sala de aula, realizei entrevistas com os sujeitos participantes, com objetivo de entender as suas trajetórias e os argumentos para as escolhas das estratégias metodológicas, de recursos, da organização do tempo e do espaço. A intenção foi elucidar os fundamentos utilizados para explicar as práticas por eles adotadas. Também interessava saber quais eram as suas concepções sobre a aula e as relações estabelecidas entre o que o docente faz e pensa acerca de suas práticas em sala de aula. Por fim, queria poder compreender como esse docente estabelecia a relação com os estudantes.

A entrevista é uma técnica que possibilita a aproximação com os sujeitos e permite que se conheça o significado evocado pelos sujeitos sobre as suas ações, suas perspectivas, concepções, valores, atitudes, que nem sempre nas observações são possíveis.

Para preservar a integridade dos sujeitos entrevistados, foi entregue o Termo de Livre Consentimento (APÊNDICE B) para o uso do conteúdo das entrevistas. Para assegurar aos sujeitos o anonimato, fiz uso de códigos, cuidado que também mantive na apresentação dos dados da observação. 
As entrevistas foram gravadas e posteriormente transcritas, mantendo a fidelidade das falas, inclusive as perguntas que não estavam no roteiro, que emergiram do diálogo espontaneamente. Isso porque não fiquei presa somente ao roteiro e em alguns momentos extrapolei-o, permitindo que os diálogos fluíssem.

Foi combinado com os sujeitos que o tempo da entrevista seria em torno de uma hora, mas em todos os casos esse tempo foi superior. Sempre que iniciava a entrevista, apresentava para eles as perguntas e informava claramente os objetivos, mesmo já os tendo expostos em uma reunião para a divulgação da pesquisa. Deixava-os livres para responder, ou não, as perguntas. Todos consideraram as perguntas coerentes e declararam que foi um momento especial, pois refletiram sobre a sua prática. Foram objetivos na maioria das respostas, exceto quando perguntados sobre a sua trajetória como docente do ensino superior. Nesse momento, todos foram cuidadosos e bastante detalhistas, e foram contando as suas histórias nos seus ritmos, fato que possibilitou uma maior profundidade.

As entrevistas foram realizadas nos ambientes e horários sugeridos pelos docentes. Cinco delas foram realizadas na própria universidade, algumas nas salas das coordenações, outras nas salas de aulas (antes do horário da aula) e uma na residência da docente. Percebi os docentes bem à vontade e expressaram as suas ideias com tranquilidade. Procurei criar um clima favorável para favorecer que os docentes e estudantes falassem livremente, e isso pode ser constatado, pois as informações que obtive ultrapassaram as perguntas. Percebi que esse momento estava sendo também utilizado pelo docente como um processo de reflexão da sua prática, como alguns explicitaram ao final da entrevista. Confesso que para mim também serviu para o questionamento de minhas próprias atividades.

\subsection{Os interlocutores: professores e estudantes}

A princípio acreditei que teria dificuldades de encontrar professores que aceitassem a minha presença na sua sala de aula, observando as suas aulas, o que de certa forma ocorreu com a docente do curso de Biologia, que não concordou em participar da pesquisa. Entre os docentes que correspondessem aos critérios estabelecidos, conhecia somente dois, ambos por trabalharem também na mesma unidade que eu. O grupo é composto de quatro docentes do gênero feminino e dois do gênero masculino. Desses, três trabalham com a disciplina de Didática-OTP, 
comum a todos os cursos de licenciatura, dois com disciplinas de Didática Específica da Pedagogia (Fundamentos Teóricos e Metodológicos dos anos iniciais e Metodologia do Ensino em História e Geografia para os anos iniciais) e um com a disciplina específica do curso de Biologia (Metodologia das Ciências e da Biologia).

Do total dos seis docentes, três encontram-se na faixa etária entre 30 e 40 anos, dois entre 41 e 50 anos e um entre 51 a 60. Com relação à titulação, todos os docentes possuem mestrado, sendo quatro em Educação e dois nas áreas específicas. Um deles, o P4, possui dois mestrados, um na sua área específica e outro na área da Educação. As docentes P3 e P5 possuem doutorado e o docente P6 está fazendo doutorado na sua área específica. Esses dados parecem indicar preocupação com a formação continuada. Desses docentes, dois, P1 e P3, fizeram especialização em Metodologia do Ensino Superior, o que aponta também a preocupação com conhecimento pedagógico. No que diz respeito à participação em cursos de atualização pedagógica, todos responderam que participam das oficinas oferecidas pela instituição duas vezes por ano, considerando os três últimos anos, e cinco informaram que participam também de congressos. A participação em eventos científicos e em cursos de atualização denota investimento na carreira acadêmica.

Com relação à experiência profissional no exercício do magistério, cinco atuaram em escola de ensino fundamental, dois (P4 e P5) continuam atuando em escola pública, um no ensino médio e a outra docente em ensino fundamental, respectivamente.

Nas entrevistas, todos os docentes indicaram que o fato de terem iniciado suas carreiras na educação básica favoreceu o seu desempenho na docência do ensino superior, e que representa um diferencial com relação aos colegas que não tiveram essa experiência.

Quanto ao tempo de vinculação dos docentes à instituição pesquisada, identifiquei que o docente P6 trabalha lá há 10 anos; a docente P1, há 12 anos; e os docentes P4, P3, P5 e P2 estão há 20, 24, 28 e 37 anos, respectivamente. Esses dados indicam que os docentes permanecem por um longo tempo na instituição e que não há, neste grupo, docentes com menos de 10 anos de trabalho na universidade pesquisada. Também é possível constatar que esses vínculos duradouros possibilitam a consolidação das relações didático-pedagógicas e parecem indicar um diferencial. 
O regime de trabalho, por se tratar de uma universidade privada, é de professor horista: o docente recebe pelas horas trabalhadas. Dos seis docentes participantes, quatro trabalham 40 horas na instituição e fazem parte ou do Núcleo Docente Estruturante (NDE) ou do colegiado do curso. As professoras P5 e P7 têm regime de 20 horas e fazem parte do NDE do curso de Pedagogia. Desses docentes, três possuem oito horas para desenvolvimento de pesquisa. Pimenta e Anastasiou (2002) afirmam que, pelo fato de participar legalmente de um colegiado, o docente da IES teria maior suporte institucional para a sua profissionalização continuada. Acredito que a inserção do docente tanto no colegiado como no NDE contribui para uma construção coletiva e um pensar sobre a constituição do curso no qual ele está inserido.

A dedicação em tempo integral ou parcial (40h ou 20h) dos docentes universitários às atividades na IES tem oferecido condições para que se dediquem à pesquisa, ao ensino e à extensão. Mesmo não constituindo uma realidade para todos, vem sendo crescente a adesão a essas atividades nas variadas áreas. No caso dos cursos que formam professores, isso tem um valor singular, pois dá oportunidade de que diminuam a distância entre a universidade e a escola de ensino básico. O maior número de turmas atendidas pelos professores é cinco. Porém, além das aulas, três dos participantes exercem outra função na universidade, sendo coordenadores de cursos. A carga horária das disciplinas é de quatro horas semanais.

Utilizando como referência os estudos de Pimenta e Anastasiou (2002), que analisam a questão de tempo de atuação nas instituições de ensino superior, quando se referem às particulares, afirmam que apenas $5,31 \%$ do total nacional dos docentes atuam em tempo integral. No caso desta pesquisa, dos seis, quatro possuem tempo integral, e os dois docentes restantes são tempo parcial. O tempo integral solicita do docente as três funções características da universidade. Nessas condições de trabalho, o tempo integral torna possível a efetivação dessas atividades.

Todos os docentes ou cursaram uma licenciatura ou um curso de formação pedagógica que os habilitou a exercer a profissão de magistério. Esses cursos lhes trouxeram benefícios, na opinião de todos os respondentes. Os conhecimentos que constroem sobre 'ensino' e 'educação' vêm das leituras e da troca de experiências com colegas, conforme a declaração de todos. O conhecimento também é adquirido 
através de palestras, cursos e outras fontes como internet, jornais, revistas. É possível interpretar a partir das suas respostas que dedicam parte do tempo e compromisso para estudos sobre 'educação', 'ensino' e 'aprendizagem'.

Como se trata de uma instituição privada, todos os participantes da pesquisa declararam que foram convidados a fazer parte do quadro de profissionais da universidade, não havendo a cultura de concursos públicos. Dos oito docentes, dois foram alunos da instituição e, após terem concluído o mestrado, foram convidados a assumir a docência.

O quadro abaixo sintetiza a caracterização dos docentes sujeitos da pesquisa.

Quadro 1 - Caracterização dos docentes participantes da pesquisa

\begin{tabular}{|c|c|c|c|c|c|c|c|}
\hline Identificação & Idade & Sexo & $\begin{array}{l}\text { Formação } \\
\text { Acadêmica }\end{array}$ & Titulação & $\begin{array}{l}\text { Experiência } \\
\text { profissional } \\
\text { docente }\end{array}$ & $\begin{array}{c}\text { Tempo no } \\
\text { Magistério } \\
\text { Superior }\end{array}$ & $\begin{array}{l}\text { Curso em que } \\
\text { atua/Disciplina }\end{array}$ \\
\hline P1 & 51 & $\mathrm{~F}$ & $\begin{array}{l}\text { Pedagogia } \\
\text { Supervisão } \\
\text { Escolar }\end{array}$ & $\begin{array}{l}\text { Mestre em } \\
\text { Educação }\end{array}$ & 12 anos & 12 anos & $\begin{array}{l}\text { Pedagogia - } \\
\text { Didática-OTP }\end{array}$ \\
\hline P2 & 64 & $\mathrm{~F}$ & $\begin{array}{l}\text { Pedagogia } \\
\text { Orientação } \\
\text { Educacional }\end{array}$ & $\begin{array}{l}\text { Doutorado em } \\
\text { Educação }\end{array}$ & 37 anos & 24 anos & $\begin{array}{l}\text { Pedagogia - } \\
\text { Didática-OTP }\end{array}$ \\
\hline P3 & 52 & M & História & $\begin{array}{l}\text { Mestrado em } \\
\text { Ciências Sociais } \\
\text { e em Educação }\end{array}$ & 28 anos & 12 anos & $\begin{array}{c}\text { Pedagogia - } \\
\text { Fundamentos } \\
\text { Teóricos e } \\
\text { Metodológicos das } \\
\text { Ciências Humanas }\end{array}$ \\
\hline P4 & 51 & $\mathrm{~F}$ & Pedagogia & $\begin{array}{l}\text { Mestrado e } \\
\text { Doutorado em } \\
\text { Educação }\end{array}$ & 20 anos & 12 anos & $\begin{array}{l}\text { Pedagogia - } \\
\text { Fundamentos } \\
\text { Teóricos e } \\
\text { Metodológicos dos } \\
\text { anos iniciais }\end{array}$ \\
\hline P5 & 48 & $\mathrm{~F}$ & Artes & $\begin{array}{l}\text { Mestre em } \\
\text { Educação }\end{array}$ & 24 anos & 12 anos & $\begin{array}{l}\text { Pedagogia - } \\
\text { Didática-OTP }\end{array}$ \\
\hline P6 & 40 & M & Biologia & $\begin{array}{l}\text { Mestrado em } \\
\text { Biologia e } \\
\text { Doutorando em } \\
\text { Biologia }\end{array}$ & 10 anos & 13 anos & $\begin{array}{l}\text { Metodologia das } \\
\text { Ciências }\end{array}$ \\
\hline
\end{tabular}

Fonte: a autora (2014)

A coleta de dados com os estudantes ocorreu em duas ocasiões. A primeira se deu nas próprias aulas, pois nesses espaços interativos foi possível perceber as trocas e as relações epistêmicas entre o docente e seus estudantes. Tive o propósito de realizar grupos focais com grupos de alunos de cada turma; no entanto foi impossível realizar com os alunos das turmas da disciplina Didática-OTP, pois os horários eram muito distintos e também em função de ter em cada turma poucos alunos dos cursos os quais estava pesquisando. As turmas tinham em média 30 
alunos dos diversos cursos de licenciatura. Contudo foram realizadas entrevistas semiestruturadas com dois estudantes de cada uma das seis turmas observadas.

No momento das observações, os próprios professores me apresentavam aos alunos dos cursos de Pedagogia e Biologia. Conversava com eles, registrava as informações, e-mail, telefones, semestre, se trabalhavam ou não em escola e horários disponíveis para realização da coleta de dados (inicialmente os grupos focais). Assim, obtive uma listagem de estudantes em cada uma das turmas. Fiz isso em todas as turmas, exceto em uma turma, pois a docente não realizou a minha apresentação e realizei esse contato somente no final das observações. Para melhor me organizar e verificar as possibilidades para a realização dos grupos focais, montei um quadro, o qual viabilizou um grande painel, pois neste primeiro momento tinha em mãos uma listagem de 25 estudantes. Os horários disponíveis eram diversos, não possibilitavam os grupos focais, pois não conseguia fechar os grupos com o número mínimo de estudantes necessários. Por falta de condições, optei em realizar as entrevistas. Então, escolhi alunos que estavam trabalhando em escola, ou realizando estágio, que cursassem semestres equivalentes, de modo que houvesse um representante de cada curso por turma.

Com os estudantes, estabeleci o mesmo procedimento de organização em relação ao tempo e ao espaço para as entrevistas. Foram agendadas antecipadamente e escolhíamos um local que os deixassem à vontade. Geralmente, as entrevistas ocorreram em salas de aula disponibilizadas para esse momento. Duas foram realizadas na biblioteca, por escolha dos estudantes. Foram disponibilizadas as leituras das questões com antecedência e o Termo de Consentimento Livre e Esclarecido foi assinado (APÊNDICE C). As entrevistas foram degravadas e, para manter o anonimato, escolhi códigos para identificá-los. Procurei ter o cuidado de preservar a linguagem falada, no entanto alguns vícios de linguagem, que acabavam dificultando a leitura das entrevistas, foram excluídos sem risco de perder a integridade da fala.

Todos os sujeitos compareceram nos dias e horários marcados, e não foram necessários novos agendamentos. Em geral, ficavam no início um pouco tímidos, mas à medida que a entrevista transcorria ficavam mais à vontade.

O grupo de estudantes que fizeram parte da coleta de dados desta pesquisa ficou constituído da seguinte forma: dois estudantes de cada uma das disciplinas, um do curso de Biologia e o outro da Pedagogia, resultando em 12 estudantes, dos 
quais oito são mulheres e quatro, homens. Sete estudantes estão na faixa entre 25 e 30 anos. Do restante, dois estão com 31 anos e 32 anos respectivamente, outro está com 35 anos e os dois restantes estão com 40 anos e 43 anos. Todos estavam vivenciando uma experiência na escola, como professores ou em situação de estágio, e cursavam entre o quinto e sexto semestre.

Em todas as turmas, foi verificado que $90 \%$ dos alunos trabalham durante o dia, ou faziam estágio extracurricular. Cabe destacar que a grande maioria dos alunos mora longe da universidade e que possuem obrigações familiares diversas. Alguns são casados ou comprometem parte da sua renda com a família. Passaram por processos formativos diversos, tais como supletivo, Educação de Jovens e Adultos (EJA) e às vezes pararam de estudar há mais de 10 anos. Seis deles recebem bolsa de estudos, cinco do Prouni e uma bolsa de extensão. Esse tipo de bolsa possibilita ao aluno o desconto na mensalidade equivalente à bolsa de Iniciação Científica da Capes, além do vínculo em um projeto de extensão para exercer monitoria.

Ressalta-se que esses aspectos caracterizam grande parte dos alunos dessa instituição, especialmente nos cursos em que foi realizada a pesquisa. Como a instituição se localiza na Grande Porto Alegre, acaba recebendo alunos de diversas localidades. Muitos deles trabalham em uma cidade e estudam em outra. Como consequência, boa parte dos alunos chega à universidade perto do horário em que a aula inicia. Alguns trazem lanche para dentro da sala de aula, pois ficam sem tempo de realizá-lo entre o final do expediente de trabalho e o início da aula. Esses fatos objetivam demonstrar, ainda que de maneira superficial, quem são os alunos que constituem as turmas que foram observadas nesta pesquisa.

Nas observações realizadas, foi verificado que uma parcela dos alunos chegava atrasada, em pequenos grupos, e entrava em sala de aula, em média 15 minutos depois do sinal. Os restantes chegavam individualmente até no máximo 30 minutos depois do início da aula. Todos os professores agiam naturalmente em relação ao atraso, cumprimentando-os com cordialidade e de certa maneira com cumplicidade, pois os alunos já tinham informado sobre essa condição.

A seguir, apresento o quadro no qual caracterizo os estudantes que participaram da pesquisa. 
Quadro 2 - Caracterização dos estudantes participantes da pesquisa

\begin{tabular}{|c|c|c|c|c|c|c|}
\hline Identificação & Curso & Disciplina & Semestre & Idade & Sexo & Docente \\
\hline E1 & Pedagogia & Didática-OTP & $\mathrm{V}$ & 27 & $\mathrm{M}$ & $\mathrm{P} 1$ \\
\hline E2 & Biologia & Didática-OTP & $\mathrm{VI}$ & 25 & $\mathrm{~F}$ & $\mathrm{P} 1$ \\
\hline E3 & Pedagogia & Didática-OTP & $\mathrm{VI}$ & 28 & $\mathrm{~F}$ & $\mathrm{P} 2$ \\
\hline E4 & Biologia & Didática-OTP & $\mathrm{VI}$ & 29 & $\mathrm{~F}$ & $\mathrm{P} 2$ \\
\hline E5 & Pedagogia & Didática-OTP & $\mathrm{V}$ & 30 & $\mathrm{~F}$ & $\mathrm{P} 6$ \\
\hline E6 & Biologia & Didática-OTP & $\mathrm{V}$ & 35 & $\mathrm{~F}$ & $\mathrm{P} 6$ \\
\hline E8 & Pedagogia & $\begin{array}{c}\text { Metodologia da História } \\
\text { e Geografia }\end{array}$ & $\mathrm{VI}$ & 32 & $\mathrm{M}$ & $\mathrm{P} 5$ \\
\hline E9 & Pedagogia & $\begin{array}{c}\text { Língua Portuguesa nos } \\
\text { Anos Iniciais }\end{array}$ & $\mathrm{VI}$ & 29 & $\mathrm{M}$ & $\mathrm{P} 3$ \\
\hline E10 & Pedagogia & $\begin{array}{c}\text { Língua Portuguesa nos } \\
\text { Anos Iniciais }\end{array}$ & $\mathrm{VI}$ & 40 & $\mathrm{~F}$ & $\mathrm{P} 3$ \\
\hline E11 & Biologia & $\begin{array}{c}\text { Metodologia do Ensino } \\
\text { de Ciências e Biologia }\end{array}$ & $\mathrm{VI}$ & 29 & $\mathrm{M}$ & $\mathrm{P} 4$ \\
\hline E12 & Biologia & $\begin{array}{c}\text { Metodologia do Ensino } \\
\text { de Ciências e Biologia }\end{array}$ & $\mathrm{VI}$ & 43 & $\mathrm{~F}$ & $\mathrm{P} 4$ \\
\hline
\end{tabular}

Fonte: a autora (2014) 


\section{PROFESSORES DE DIDÁTICA E SEUS ESTUDANTES: OS ARTÍFICES DA FORMAÇÃO}

A análise dos dados foi sendo desenvolvida na medida em que iam sendo recolhidos, tendo em conta as questões que haviam sido propostas. Contudo, de posse de todas as informações coletadas, ficou mais clara a dimensão dos desafios que tinha pela frente. À medida que lia os registros das observações, procurava encontrar elementos que iluminassem a análise. Assim, fui destacando aspectos que considerava significativos, sistematizando-os através dos registros em forma de quadros, buscando delinear as categorias.

Em paralelo a esse exercício, recorri aos estudos teóricos e, aos poucos, fui avançando. Por se tratar de um grupo com uma diversidade de práticas e vivências singulares, optei por não realizar um processo comparativo, mas buscar e considerar as singularidades dos sujeitos e as especificidades das suas trajetórias e práticas.

Iniciei com a análise dos fatos observados em sala de aula para definir as categorias e proposições teóricas, enquanto que as construções explicativas e interpretativas foram elaboradas no decurso da pesquisa, pela interação com os quadros de referência conceituais disponíveis. As observações nas salas de aula permitiram que fosse visualizado como os sujeitos estabeleciam as relações e articulações do fazer pedagógico, suas histórias de vida e expectativas, tanto dos docentes como dos estudantes.

Minha pretensão foi articular a observação com a análise teórica da prática pedagógica em situação de trabalho. Acredito que, por meio das observações e entrevistas, foi possível conhecer a trama dessas relações.

Para a análise dos dados qualitativos, utilizei a análise de conteúdo baseada em Bardin (1977), a fim de sistematizar os achados, relacionando-os com construções teóricas já produzidas. Segundo o autor, a análise de conteúdo é

[...] um conjunto de técnicas de análise de comunicação visando obter, por
procedimentos sistemáticos e objetivos de descrição de conteúdo das
mensagens, indicadores (qualitativos ou não) que permitam a inferência de
conhecimentos relativos às condições de produção/recepção dessas
mensagens. (ibidem, p. 42).

Nesse processo, após ler e reler as transcrições, procurando apreender e entender os relatos, retomei o diário de campo com o objetivo de realizar a triangulação entre os registros realizados na sala de aula, as entrevistas com os 
docentes e estudantes e o referencial teórico. Foi importante para perceber a coerência entre as dimensões e categorias elencadas e organizadas. Após a análise e o cruzamento dos dados obtidos, o próximo passo foi verificar se os resultados obtidos respondiam às questões da investigação, no sentido de chegar a algumas conclusões.

\subsection{Pensando o vivido através das observações}

É a experiência que nos imprime a necessidade de repensar, de voltar sobre as ideias que tínhamos das coisas, porque justamente o que nos mostra a experiência é a insuficiência, ou a insatisfação de nosso pensar anterior. (CONTRERAS; PÉREZ DE LARA, 2010, p. 21).

Como explicitado no capítulo anterior, os registros das observações foram realizados em um diário de campo. Esse instrumento permitiu que fossem registradas as falas e as atitudes de professores e alunos investigados nesta pesquisa.

A observação permitiu registrar as intenções percebidas em alguns aspectos não verbais, incluindo gestos e silêncios que ocorriam durante as aulas. Estas foram realizadas ao longo do ano, não havendo regularidade nas datas, somente em turnos, pois as disciplinas foram oferecidas no noturno. Iniciei observando as aulas da disciplina Didática-OTP que ocorriam nas terças-feiras, com a docente P1. Concomitante a elas, assisti com a docente P2 a mesma disciplina oferecida nas quintas-feiras e uma das disciplinas de Didática Específica - Metodologia do Ensino em História e Geografia para os anos iniciais - do curso de Pedagogia, com o docente P3, nas sextas-feiras. Após observar por quatro semanas cada um desses docentes, iniciei a segunda fase das observações com a disciplina de Didática-OTP com a docente P4, nas sextas-feiras, e a docente P5, nas terças-feiras, com a disciplina de Metodologia da Linguagem. Essa disciplina é específica do curso de Pedagogia. No semestre seguinte, observei a disciplina de Didática Específica do curso de Biologia, pelo motivo relatado anteriormente. Registro que as observações não foram agendadas previamente. Somente a primeira aula. Essa condição sugere que as aulas não foram planejadas para atenderem às minhas expectativas, embora não possa afirmar com segurança de que alguma alteração não ocorresse, pelo fato 
de que as aulas seriam observadas. No entanto pareceu-me que os docentes agiram de forma o mais natural possível durante todas as minhas observações.

O diário de campo serviu para descrever e analisar o cotidiano da pesquisa, e foi um instrumento importante, pois registrei as cenas, as falas e as atitudes que presenciei durante as aulas. Realizei anotações também fora da sala de aula, como as conversas com os docentes no final das aulas, quando íamos juntos até o estacionamento. Muitas dessas conversas eram ricas em informações, que muitas vezes não eram captadas durante as observações. Não raras vezes conversamos sobre o que havia ocorrido durante a aula e explicavam a realidade e os problemas que um ou outro aluno estava passando. Comentavam o que haviam planejado para a próxima aula, entre outras coisas. Sempre coloquei o meu diário em cima da classe e disponibilizei para eles, caso tivessem interesse em ver as anotações. Fazia a leitura do diário quando retornava para casa e buscava rever as anotações e verificar se algum aspecto significativo não tinha sido registrado.

Considero esse momento da pesquisa riquíssimo, pois a cada aula observada vivenciei diferentes momentos, aprendi muito, o que me leva a recorrer ao conceito de experiência, que encontro em Larrosa, 2002. Para ele, experiência é o que nos passa, o que nos acontece, o que nos toca; não o que se passa, não o que acontece, ou o que toca. A cada dia se passam muitas coisas, porém, ao mesmo tempo, quase nada nos acontece. A experiência é vivida, cristalizada pelo sujeito, não é temporária, transitória - ela deixa marcas. O sujeito que vive a experiência pode ser transformado por ela.

Hacer sonar la palabra "experiencia" en educación tiene que ver, entonces,
con un no y con una pregunta. Con un no a eso que se nos da como
necesario y como obligatorio, y que ya no soportamos. Y con una pregunta
que se refiere a lo otro, que encamina y señala hacia lo otro (hacia otros
modos del pensamiento, y del lenguaje, y de la sensibilidad, y de la acción,
y de la voluntad) pero, eso sí, sin determinarlo. Sólo porque aún queremos
seguir vivos, seguir. Y porque aún intuimos, o creemos intuir, un afuera. Un
afuera de ese sótano que nos encierra, pero del que sabemos que no será
nunca lo que creemos que podría ser. Hay que abrir la ventana. Pero
sabiendo que lo que se ve cuando la ventana se abre nunca es lo que
habíamos pensado, o soñado, nunca es del orden de lo pre-visto. Por eso la
pregunta por el "de qué otro modo" no puede ser otra cosa que una
apertura. Hacia lo que no sabemos. Hacia lo que no depende de nuestro
saber ni de nuestro poder ni de nuestra voluntad. Hacia lo que solo puede
indeterminarse como un quién sabe, como un quizás. (ibidem, p. 88).

Esse entendimento em relação à investigação pedagógica, afirma Larrosa Bondía (ibidem), é sempre uma forma de autoinvestigação e que, no processo, 
abrimo-nos para novas experiências e compreensões de coisas que não entendíamos.

Colocar a experiência educativa no cerne dos processos de formação profissional implica pensar, agir, falar e escrever "a partir de si" (CONTRERAS; PÉREZ DE LARA, 2010), num movimento de exploração do espaço entre o real e o ideal, questionando e reconstruindo o sentido da experiência e, assim, a identidade profissional.

É nesse sentido que me propus a realizar a exploração das observações das aulas realizadas durante a pesquisa, procurando ligar os fios que tecem a relação entre o realizado dentro da sala de aula e o que foi dito e o que é feito pelo professor. Ainda conforme Contreras e Pérez de Lara, encontrar o fio - ou os fios de sentido e procurar visualizar os percursos dos sujeitos investigados, observar como eles atravessam a experiência é tarefa do processo de investigação. Além disso, pode-se ver como eles constroem as suas próprias tramas e tecem outros sentidos com novas experiências.

A pesquisa teve o seu início a partir da observação. A princípio, considerava que seria interessante começar pelas entrevistas, no entanto, como o semestre já havia iniciado e houve demora para que eu conseguisse a autorização institucional para a realização da pesquisa, optei em observar as aulas e somente após, já munida com o material da observação, realizar as entrevistas.

Para as observações, não foi utilizado nenhum roteiro prévio. Foi decidido entrar em sala de aula com olhar curioso e atento para poder perceber todas as relações que ocorriam dentro desse espaço. Em todas as observações, chegava antes da professora, ficava sempre do lado de fora da sala, pois previamente eu já tinha a informação da sua localização no prédio.

Do grupo de seis professores pesquisados, três no primeiro dia me apresentaram aos seus alunos e solicitaram que eu fizesse uma breve exposição da proposta da tese e dos motivos que me levaram a estar nas suas salas de aula. Elas me deixaram à vontade e nesse primeiro dia escolhiam um lugar no fundo da sala para mim, porque assim poderia observar como elas interagiam com o espaço e com o grupo de alunos - isso quando a sala de aula estava organizada com as classes uma atrás da outra. Mas foram raras as aulas em que os alunos se organizavam assim. 
Esse fato acabou facilitando as observações, pois no fundo da sala não poderia observar as reações dos alunos no momento em que os professores interagiam com eles. Normalmente os alunos iam chegando e organizando a sala conforme haviam combinado com os professores na aula anterior, e eu fazia o mesmo. Tinha em mãos o diário de campo, procurei ficar atenta, concentrada o período inteiro da aula. Havia combinado previamente com os professores que ficaria em silêncio nas suas aulas, mas repetidas vezes fui convidada a participar da aula. A minha presença causava diferentes reações para cada docente. Não percebi nenhuma insegurança ou insatisfação ao fato de eu estar na sala de aula. Três docentes me incluíam nas aulas, solicitavam opinião com relação às temáticas desenvolvidas, ou as atividades que propunham. Esses movimentos realizados por elas propiciavam um ambiente descontraído e muitas vezes tive que me controlar, deixar de lado a professora, que estava dentro de mim, para não opinar sobre os questionamentos que eles realizavam.

O professor P3 era mais discreto. Na primeira aula fez a apresentação, informou que eu estava realizando uma pesquisa de doutorado, que os acompanharia durante quatro aulas subsequentes e que no final os alunos iriam colaborar. Muitas vezes, fazia como se eu não estivesse em sala, outras vezes buscava com o olhar a minha aprovação, em situações onde havia questionamentos e certa tensão. Esse professor utilizava para as suas aulas diferentes espaços físicos. A primeira aula foi realizada na sala que estava prevista. A segunda foi realizada em uma escola localizada em um bairro próximo da universidade. A terceira, em um espaço de convivência de uma das livrarias da universidade, com a presença de uma autora de literatura infanto-juvenil; e a última, em uma sala temática de ensino de História e Geografia.

O professor P6 e a professora P5 ignoraram a minha presença. Era como se eu não estivesse ali. P6 fez questão de me apresentar e dizer aos seus alunos o porquê de eu estar realizando as observações na sua sala. Mas não abriu espaço para apresentação. A professora P5 não comentou com os alunos sobre a minha presença na sala de aula. Durante toda a primeira aula, os olhares dos alunos perguntavam quem eu era, talvez uma colega nova. No final da aula, uma aluna chegou perto e perguntou se eu precisava de ajuda, e caso não tivesse ainda algum grupo, poderia me juntar ao grupo ao qual ela pertencia, para a atividade solicitada pela professora, para a próxima aula. Então, expliquei o que estava fazendo na sua 
sala de aula. Em poucos minutos, todos já me olhavam e sorriam. A professora P5 somente me apresentou no último dia de observação.

Esses registros permitiram visualizar, no momento da escrita, cada professor e todas as suas ações. As observações foram feitas de acordo com o horário de cada professor nas respectivas disciplinas. As aulas tinham duração de três horas, iniciando às $19 \mathrm{~h}$ e finalizando às $22 \mathrm{~h}$. Com relação ao tempo, cada professor organizava à sua maneira. Farei os comentários à medida que descreverei as suas aulas. Procurei observar esses professores com o mesmo número de encontros. Em alguns se estenderam um pouco mais as observações, pois não seria interessante finalizar antes do fechamento das atividades. Em média, foram observadas quatro noites, que equivalem a 16 horas-aula para cada um dos professores. Cada professor é único e imprime ao seu fazer docente - em um cenário marcado pela complexidade e pela contradição - a sua direção, a sua prática pedagógica.

Segundo Tardif et al. (2000, p. 231), "os saberes da experiência servem como objeto/condição de retradução e de validação de conhecimentos outros para a prática”. Sendo assim, o ser professor para cada um está presente nos saberes da experiência construídos no cotidiano.

Ressalto que, à medida em que trabalhei os registros no diário de campo, percebi que tinha em mãos ingredientes que me permitiam visualizar cada professor e compreender e descrever sua prática no cotidiano da sala de aula. Procurei, então, enxergar deliberadamente a complexidade da ação pedagógica desses professores. Para melhor compreender o significado dos processos observados em situação de trabalho em sala de aula, realizei as entrevistas, com o objetivo de conhecer as trajetórias desses docentes e as suas principais influências, os valores e a compreensão pedagógica que revelam seus discursos. Procurei entender quais as fontes de saberes que nominam como preponderantes em sua formação e as experiências que consideram mais significativas para definir suas práticas, entre outras. Cabe aqui relatar que havia também o interesse em conhecer suas concepções sobre a aula, sobre a aprendizagem dos seus alunos, verificar como era estabelecida a relação entre o que o docente faz e o que pensa sobre a sua prática em sala de aula e a influência das suas ações na formação dos estudantes dos cursos de licenciatura.

Para Viñao Frago (2001) a colocação do mobiliário não acontece por acaso. A sua distribuição gera segurança, pois o ser humano necessita de precisão e de 
regularidade, normalização e racionalização, e tais itens "realizam-se mediante dispositivos e engrenagens mecânicas ou organizações maquinais de seres vivos", seres humanos (VIÑAO FRAGO, 2001, p.139). Ao alterar o interior ou o exterior, o autor afirma que mudamos a natureza do lugar. Isso significa que se deve "abrir o espaço escolar e construí-lo como lugar de modo tal que não restrinja a diversidade de usos ou sua adaptação a circunstâncias diferentes" (ibidem, p. 139). É importante dar liberdade ao professor na configuração de espaços. A sala de aula é um espaço dinâmico, portanto deve ser um ambiente facilitador de tal processo.

Assim,

[...] quando nossa subjetividade atribui sentido aos lugares, eles se tornam parte de nós mesmos. Eles constroem nossa história e neles deixamos parte de nós. Durante algum tempo foram lugares em que algo de nós ficou e que, portanto, nos pertence; que são nossa história... (ibidem, p. 139).

Ainda em Viñao Frago (ibidem), constato que o espaço escolar pode influenciar o comportamento de todos. Na sala de aula, se existe luz refletindo no quadro negro, o aluno evitará sentar-se nas classes que causam esse desconforto; se ele sentir muito calor, vai se sentir desconfortável, da mesma forma que o frio excessivo enrijecerá sua mão para escrever. A temperatura altera profundamente nosso comportamento, por isso é tão importante que o projeto de escolas tenha a orientação solar adequada.

\subsection{As trajetórias dos professores e as suas principais influências}

Falar sobre as trajetórias dos docentes pesquisados não se constitui em uma tarefa simples. Primeiro porque parto da premissa que cada sujeito é único, por isso não tenho a menor pretensão de compará-los. À medida que realizo essa análise, busco aproximações e distanciamentos nas trajetórias que eles foram construindo ao longo das suas carreiras. Quando solicitados para contar como se tornaram docentes no ensino superior, todos foram unânimes em afirmar que não houve uma preparação prévia para que isso ocorresse. Tinham o desejo de serem professores desde crianças, mas trabalhar na universidade era muito distante das suas realidades. Cito a fala de três docentes. 
Eu sempre quis ser professora, desde o primeiro dia que botei o pé na escola. Naquele tempo eu morava na periferia e a escola mais próxima já era muito longe. E quando terminei o primeiro grau, eu e minha mãe andamos por todo canto procurando uma escola que tivesse magistério noturno. Eu já trabalhava de dia para poder ajudar a família e eu não podia abrir mão disso. Então disse para minha mãe, vou fazer o segundo grau em PPT e depois eu faço o magistério. (P1)

Comecei a pensar em ser professor do ensino superior a partir da minha vivência na graduação, pois fui bolsista de iniciação científica. Essa minha inserção propiciou que eu começasse a olhar a licenciatura como uma possibilidade, pois estar cursando uma graduação já era bastante distante da realidade da minha família. Na graduação, comecei a viver pesquisa e considerar importante para qualquer nível de ensino. Fui instigado pelos meus professores a fazer o mestrado e me candidatei a fazer o mestrado em Sociologia. Assim que eu estava quase terminando o mestrado e fui convidado para trabalhar em outra instituição, com um contrato de prestação de serviço, eu vi que era possível, eu estava estudando, me preparando para isso. Mas ao mesmo tempo não era o meu objetivo de vida, mas tudo estava se encaminhando para isso. Então ser professor na universidade foi uma consequência. (P3)

Comecei a trabalhar em outra instituição, fui convidada pela minha irmã para fazer um concurso. Já tinha terminado o mestrado há bastante tempo, mas não havia me animado a fazer concurso para o ensino superior. Eu tinha 40 horasaula na SMED em Porto Alegre na assessoria pedagógica. (P4)

A docência dos professores se constitui não somente sobre suas representações quanto a ex-professores e estudantes, mas também sobre sua área do conhecimento e sobre a sua docência, de um modo geral. Os estudos de Cunha (2004) e Anastasiou (1998) afirmam que o modo como o professor desenvolve a sua docência, ainda que não esteja muito claro para ele, está fundamentado em modelos dos seus ex-professores, de como eles desenvolviam as suas aulas, as questões didáticas. Os professores investigados citaram a importância dos modelos de seus ex-professores e a admiração que sentem por eles. Também mencionam o que eles não gostariam de ser, relembrando professores que consideram exemplos negativos.

Sim, tive excelentes professores, aprendi muito com eles. Adorava assistir aulas com a professora Sandra, ela sabia muito, tinha muito conhecimento. Ela me inspirou e me ensinou que para ser professor do ensino superior é preciso ter muito conhecimento. O que mais me chamava a atenção é a dedicação com que eles realizam o seu trabalho e o prazer do conhecimento que eles demonstram no seu olhar. Acho que essa foi a coisa que os meus professores me ensinaram, falavam com propriedade as questões teóricas, pareciam de outro mundo. $O$ 
conhecimento deve fazer parte do professor universitário, o aluno tem que ter segurança com relação a isso. (P4)

A minha experiência com a docência teve início no ensino médio, eu queria ser irmão Lassalista, e a missão deles está ligada ao ensino, por isso comecei a trabalhar em sala de aula. Fazíamos um curso que nos ensinava a didática e a metodologia para ensinar nas escolas do município que eles tinham convênios para dar aulas de religião, em uma proposta mais ecumênica. Foi ali que aprendi muito, tive colegas que me ajudaram, pois já tinham mais experiência. Um formado em física e química sabia bem fazer o planejamento, as aulas dele eram muito boas. Outro colega tinha um jeito mais descolado, não tinha graduação assim como eu, mas sabia como fazer, era parceiro, ajudava todo mundo. Teve um fato que lembro até hoje, fazia os meus planejamentos, mas nunca dava certo. Então resolvi que iria largar o planejamento, vou inventar na hora, já que nunca dá certo mesmo! Mas esse colega e o grupo de professoras do magistério (Escola Lassalista) disse para eu não abandonar o meu planejamento. Falava para eu ir até o final e depois ver por que havia dado certo, ou errado. (P6)

Tenho como referências os meus professores; os que elegi foram muito afetuosos e afetivos, sempre próximos dos alunos, disponíveis, que me incentivaram muito. Além disso, eles eram cultíssimos, que utilizavam uma linguagem rebuscada, com uma cultura vasta, sempre tinham coisas novas para me dizer, isso me marcou muito. Por isso nas minhas aulas sempre procuro discutir temas que elevem a cultura do meu aluno. (P3)

Pimenta e Anastasiou (2002) alertam que os professores, quando chegam à docência na universidade, trazem consigo inúmeras e variadas representações e experiências do que é ser professor. Os saberes pedagógicos podem colaborar com a prática. Sobretudo se forem em decorrência dos problemas que a prática apresenta, entendendo a dependência da teoria em relação à prática, assim como as experiências que adquiriram como alunos de diferentes professores ao longo da sua vida escolar. Esse fato fica latente na fala de cinco dos docentes pesquisados. Para eles, essas experiências lhes possibilitaram identificar os bons professores e o que eles faziam em sala de aula para que os considerassem bons.

Quais eram bons em conteúdo, mas não em didática, isto é, não sabiam ensinar. Formaram modelos "positivos" e "negativos", nos quais se espelham para produzir ou negar. Quais professores foram significativos em suas vidas, isto é, que contribuíram para sua formação pessoal e profissional. (ibidem, p. 81).

Tive alguns professores que me ensinaram a como não ser professor, ou seja enquanto assistia as aulas deles pensava que não faria como eles. Por exemplo: não aceitavam as ideias dos alunos, diziam que estavam errados, faziam os alunos ficarem envergonhados. Por isso, hoje aproveito sempre a fala dos meus 
alunos. Quando falam algo que não tem nada a ver com o assunto, peço para eles pensarem sobre o que falaram, faço vários questionamentos, e vou com o aluno até fazer sentido o que ele falou. (P5)

No depoimento acima, percebe-se a necessidade de que uma atitude reflexiva se estabeleça. O professor manifesta valores, tais como: não se ver como detentor de um saber acabado, permitindo-se aprender constantemente; compreender que os modelos são construídos em conjunto; lidar com as dúvidas e incertezas como parte do processo de aprendizagem, compartilhando os saberes e fazeres da prática pedagógica.

Também explicita o quanto se aprende a profissão pelas práticas dos seus ex-professores, ou seja, pelas experiências metodológicas dos processos de ensinar e aprender que vivenciaram. Trata-se de uma didática vivida, que tem muito mais impacto na formação do que os discursos sobre as formas de aprender. Novamente se confirma a ideia de que na formação de professores forma é conteúdo.

Certamente, quanto mais essa condição for acompanhada de reflexão mais efetiva e consistente, mais ela se fará nesse processo formativo. De acordo Bolzan (2002, p. 17):

\begin{abstract}
Ao refletir sobre sua ação pedagógica, ele estará atuando como um pesquisador da sua própria sala de aula, deixando de seguir cegamente as prescrições impostas pela administração escolar (coordenação pedagógica e direção) ou pelos esquemas preestabelecidos nos livros didáticos, não dependendo de regras, técnicas, guias de estratégias e receitas decorrentes de uma teoria proposta/imposta de fora, tornando-se ele próprio um produtor de conhecimento profissional e pedagógico.
\end{abstract}

No caso desta pesquisa, os docentes têm significativa responsabilidade pela formação dos futuros professores, e isso representa um compromisso importante com a qualidade da educação.

Os interlocutores mencionaram como um problema o fato de alguns não terem tido experiência docente em outros espaços escolares além da universidade. Parece que, para atuar em cursos de licenciatura, essa condição faz diferença, pois sua trajetória profissional está alicerçada apenas nos modelos de professores que tiveram na universidade enquanto alunos.

Como te disse no início da entrevista, sempre quis ser professora, mas por contingências da vida acabei não cursando o magistério. Cursei a Pedagogia e acabei entrando para a universidade como funcionária em um setor, o NOE 
[Núcleo de Orientação Educacional], como supervisora. Sinto muita falta dessa vivência em escola. Leio bastantes pesquisas e trabalhos que se referem a essa realidade, mas não é a mesma coisa. (P1)

A docente $\mathrm{P} 2$, responsável pela disciplina de Didática-OTP, é pedagoga com pós-graduação, mestrado e doutorado em Educação. Tem experiência na educação básica e atua há vários anos na educação superior. Valoriza essa condição e, durante a entrevista, evidenciou que sua opção pela carreira docente foi marcada por um fato específico.

Eu nasci professora, eu nunca pensei em outra profissão. Desde criança lia
muito, estudava. Sempre quis, sempre gostei e não me vejo atuando de outra
forma. Até tentei, pois onde eu morava todas as moças trabalhavam em banco,
era o máximo. Comecei a trabalhar, mas estava voltando para casa e vi duas
crianças saindo da escola tentando atravessar a estrada, eu peguei nas mãos
delas e as atravessei. Pensei o que eu estou fazendo trabalhando naquele
banco? Tantas coisas eu poderia fazer por essas crianças. Cheguei à casa e
falei para os meus pais, vou voltar para o banco e pedir demissão, quero ser
professora, sempre quis. Fui e me matriculei no magistério. (P2)

As características da formação acadêmica, a opção pela profissão docente e as condições objetivas de atuação certamente influenciaram a postura da professora e sua experiência profissional ampla, em meio à vivência na complexidade do trabalho docente em sala de aula.

Em relação à opção pelo magistério, nenhum dos docentes investigados afirmou ter forte influência da família. Entretanto certamente viveram em contextos de valorização da educação escolarizada e da figura do professor.

De acordo com Sousa Santos (2000, p. 55),

[...] no campo da formação docente, busca-se conhecer como o professor é formado nas e pelas instituições escolares, seja na sua formação inicial, ou antes dela, seja pela sua prática profissional. Busca-se também compreender como sua história de vida e trajetória profissional se intercruzam, modelando seus comportamentos, suas perspectivas profissionais e sua visão e concepções sobre a educação, o processo de ensino e organização do trabalho escolar.

Nóvoa (1992) chama a atenção para o percurso histórico da formação da profissão docente, a fim de pensar a formação de professores. Opondo-se à racionalidade do trabalho dos professores compreendida como funcionários, ora da Igreja, ora do Estado, meros aplicadores de valores, normas, diretrizes e decisões político-curriculares, o autor aponta para a importância do triplo movimento sugerido 
por Schön, ou seja, da reflexão na ação, da reflexão sobre a ação e da reflexão sobre a reflexão na ação. Crê que são constituintes do professor, compreendido como profissional autônomo.

Tanto nas entrevistas quanto nas observações das aulas percebi indicativos de que os professores consideram importante essa condição. Também ficou explícito o valor que dão à participação dos alunos, quando juntos reformulam suas formas de agir e pensar a prática pedagógica. Há a confirmação de que para eles a prática docente é construída nesse processo dialógico com seus estudantes na aula e que essa competência se desenvolve ao longo da vida profissional.

Outro ponto significativo com relação ao depoimento dos interlocutores diz respeito à superação entre a dicotomia teoria-prática, tão comum nos espaços acadêmicos. Pimenta (2005, p. 26) considera que "os saberes teóricos propositivos se articulam, pois, aos saberes da prática, ao mesmo tempo ressignificando-os e são por eles ressignificados". Para a autora, teoria e prática devem ser consideradas inseparáveis, pois sempre há um diálogo entre conhecimento pessoal e ação. Essa perspectiva se confirma na perspectiva de nossos interlocutores.

Parece que quando se reflete acerca de práticas profissionais há uma tendência à autoformação, sem que isso dispense políticas de formação docente. No entanto $\mathrm{o}$ ato de formar-se não é apenas uma ação burocrática, e sim de aprendizado, de mudança a partir de diversos procedimentos pessoais e coletivos. Esse mecanismo está em parte na prática reflexiva proposta por Schön (1992) na qual a formação de professores se faz através de uma epistemologia da prática, em que as investigações partem da prática e voltam para ela. Nossos sujeitos reconhecem que o professor necessita de suportes teóricos para a realização do seu ofício docente e que a formação não se faz somente pela prática. As teorias são imprescindíveis, pois dão subsídios aos professores para que estes compreendam suas práticas a partir dos contextos sociais em que vivem.

Os docentes investigados entendem que não pode existir a separação entre teoria e prática, porque uma não existe sem a outra, e que a relação que se estabelece entre elas é muito rica, além de necessária.

Bem, atualmente é impossível dar aulas descontextualizadas, é necessário contextualizar o conteúdo que vou trabalhar no tempo e no espaço. É preciso que os alunos aprendam a lidar com o conhecimento que adquirem na universidade. Acredito que o currículo do curso de Pedagogia, hoje, propicia 
muito isso. Os alunos entram em contato com o mundo da escola bem no início do curso e isso facilita muito, pois assim ele já tem contato com a realidade da escola e estabelece a relação entre o que aprende aqui a teoria e a prática na realidade. (P5)

Quando perguntada sobre que atividade desenvolviam com os alunos e que propiciava esse contato com a realidade e a articulação entre a teoria e a prática, uma das colegas respondeu:

Na realidade muitas atividades são realizadas, não só aquelas em que os alunos são encaminhados para desenvolverem atividades nas escolas. É claro que sempre com objetivos bem claros, definidos e supervisionados, neste caso por mim. Por exemplo, irem até a escola e pesquisar sobre como é construído o Projeto Pedagógico da escola. Mas também em sala de aula faço isso sempre. Outro exemplo, com relação ao planejamento, trabalhamos como construímos o planejamento e eles desenvolvem uma aula para os colegas. As avaliações também. Eles constroem as provas e desenvolvem com os colegas da turma, além de elaborar eles têm que corrigir. Também têm que aprender a construir os critérios para avaliação. Eles experimentam exercer o papel do professor. Sem a teoria de como fazer, fica sem sentido o fazer. (P2)

Também registraram a importância da relação não dicotômica entre a teoria e a prática, enfatizando a questão do currículo do curso como um propulsor nessa direção. Eis um depoimento:

Nesta disciplina realizamos várias atividades práticas, sempre baseadas em
estudos de textos. Considero muito importante eles lerem pesquisas realizadas
sobre o assunto, assim eles se aproximam de trabalhos acadêmicos.
Construímos materiais para trabalharem nas escolas, agora com o Pibid, tenho
alguns alunos que são bolsistas. Acabam sempre trazendo essa realidade para
a sala de aula e nós desenvolvemos as aulas com práticas que eles possam
usar no seu cotidiano. (P5)

Veiga-Neto (2003, p. 4) contribui para debater tão importante questão.

[...] sem um esquema ou arcabouço teórico, isso que chamamos mundo das práticas - ou, simplesmente, práticas - não faz nenhum sentido e, assim, nem é mesmo observado ou visto e nem, muito menos medido ou registrado. Inversamente, se dá o mesmo: sem alguma experiência, algum acontecimento nisso que chamamos mundo das práticas, não há como pensar, formular ou desenvolver uma ou mais teorias.

Percebi que as ações dos docentes acabam levando em conta todo o contexto que envolve a sala de aula, servindo, além de mediador do conhecimento e 
da aprendizagem, também como motivador no processo educativo. Além disso, suas experiências podem servir de exemplos que enriqueçam a prática docente, levando em conta todas as suas construções e vivências anteriores a esse processo e que poderão influenciar diretamente nas práticas pedagógicas que desenvolvem. Mas é preciso dar sentido à experiência para não cair na armadilha do praticismo.

Foi possível perceber que a formação do professor do ensino superior não se constitui somente baseada na racionalidade técnica, que considera os professores executores de 'decisões alheias', ou seguidores de manuais de metodologia de ensino. A formação a que me refiro é da mesma natureza da que encontrei nos autores que serviram de base a esta tese e que pode ser sintetizada na seguinte citação de Anastasiou e Pimenta (2002, p. 264):

O professor, ao confrontar suas ações cotidianas com as produções teóricas, impõe-se rever suas práticas e as teorias que as informam, pesquisando a prática e produzindo novos conhecimentos para a teoria e a prática de ensinar. Assim, as transformações das práticas docentes só se efetivam à medida que o professor amplia sua consciência sobre a própria prática, a da sala de aula, a da universidade como um todo, o que pressupõe os conhecimentos teóricos e críticos sobre a realidade.

A superação da dicotomia teoria e prática parece ser possível na medida em que se considera a prática docente uma prática social que contribui para formar as novas gerações, como o ponto de partida para empreender mudanças no cotidiano do ensinar e aprender. Ouvir o aluno, fazer a leitura de sua vida cotidiana, os significados que atribui ao seu percurso de formação e suas expectativas de vida se constituem numa condição para envolvê-lo na aprendizagem.

A formação pedagógica do professor universitário, hoje, inscreve-se num complexo panorama de redefinições das funções sociais da educação superior, exigindo que seja pensada e materializada como um processo de desenvolvimento no qual estão imbricadas as histórias pessoais de inserção na docência, as condições institucionais do trabalho acadêmico, os determinantes das políticas públicas, as trajetórias constitutivas dos docentes e seus encontros com os alunos, os dilemas presentes na reconfiguração da ciência e de seu lugar na sociedade (BATISTA, 2002). Percebi similaridade com essas ideias no depoimento de um dos interlocutores:

Durante a minha graduação, eu não pensava em ser professor universitário, queria ser professor de escola pública, mas acabei me encantando com o mundo 
acadêmico. Mas percebi que não tinha aprendido a ser professor da universidade. Então procurei fazer um pós em metodologia do ensino superior, aprendi algumas coisas, mas entendi principalmente que deveria estudar mais, então ingressei no mestrado. Acredito que aprendi muitas coisas no mestrado, mas não me ensinaram a dar aulas criativas, inovadoras. A prática docente dos meus professores era extremamente tradicional. Percebi então que fui aprendendo na prática, na minha prática. Vendo o que os professores mais antigos faziam, lembrando o que os meus professores faziam eu repetia, mas sempre fazia algo diferente. (P4)

Marcelo García (1997) lembra que a iniciação profissional dos professores se constitui em uma das fases muito importantes do "aprender a ensinar". Entretanto muitas vezes tem sido esquecida como espaço preferencial de formação. A LDB 9.394/96, em seu artigo 66, quando se refere à formação de professores para o ensino superior, menciona que a preparação para o exercício do magistério superior far-se-á em nível de pós-graduação, prioritariamente em programas de mestrado e doutorado. Mas não dá ênfase à educação continuada desses professores nem à fase de inserção profissional na carreira. Além disso, como é do conhecimento geral, são raros os programas de pós-graduação stricto sensu que demonstram alguma preocupação com os saberes da docência.

O Decreto 2.207/97, que regulamenta o Sistema Federal de Ensino, por sua vez, determina que as instituições de ensino superior, até o segundo ano de sua existência, tenham entre os seus professores 15\% de docentes titulados na PósGraduação stricto sensu - sendo 5\% de doutores; no quinto ano, tenham 25\%, sendo $15 \%$ de doutores; e no oitavo ano, um terço, sendo 15\% de doutores.

No entanto a Lei não menciona o processo de formação para a docência. Cunha (2004) cita que, quando é exigida a titulação de mestres e doutores, a legislação se preocupa com a capacidade de pesquisador que o docente deverá apresentar. Portanto o trabalho docente é fundamentalmente identificado com a atividade de pesquisa, sendo esta sua principal fonte de prestígio acadêmico e também de valorização profissional. Em uma universidade privada, essa condição fica ainda mais latente. Nela, existe um período para submissão de projetos de pesquisa, para que os docentes se inscrevam por meio de edital público, desde que se enquadrem nos critérios para submetê-los. Certamente não se questiona a importância da atividade de pesquisa, pois compreendo que o exercício da docência universitária não pode prescindir da boa formação do pesquisador, visto que ensino, pesquisa e extensão devem ser atividades indissociadas. Mas o que quero pôr em 
discussão é a opacidade dos saberes do ensino, como se esses não fossem importantes.

De certa forma, essa condição ficou manifesta nos depoimentos de todos os docentes, tanto dos que possuem horas de pesquisa, quanto dos que não possuem tempo específico para essa atividade. Dizem eles: Considero fundamental o nosso aluno ter contato com pesquisa, saber construir
um projeto e desenvolver a pesquisa. Sempre disponibilizo um tempo para
conversarmos sobre isso, mesmo que não seja um conteúdo específico da
disciplina que trabalho, mas sei o quanto é importante. Trago sempre para eles
pesquisas realizadas, e é claro que a pesquisa que estou realizando aparece
com frequência nas minhas aulas. (P3)

A pesquisa faz parte das minhas aulas, lemos muitas pesquisas realizadas por grupos de pesquisa sobre a temática que trabalho nessa disciplina. Eles são convidados a realizar uma pequena empiria na escola. Depois escrevem um artigo. Neste semestre tivemos dois artigos excelentes e vamos publicá-los em um livro que fui convidada a escrever. (P5)

Nessa perspectiva, a teoria é de grande valia, desde que não seja restrita apenas a ser aquilo que orienta a prática, e sim quando ressignifica o objeto e possa ser compreendida de tal forma, contribuindo para a pesquisa e para a reflexão. Como nos ensina Cunha (2001, p. 84), "o pensamento teórico, fruto de inúmeras formulações só adquire sentido quando o presente e o passado são estímulos para o diálogo de significados entre o que o texto quer expressar e o que o leitor percebe".

O trabalho do docente formador vem exigindo uma combinação do profissional com uma condição de intérprete do conhecimento, além de habilidades que suscitem no aluno o sentimento de responsabilidade pela construção de seu próprio saber. Freire (1996) considera que a reflexão do professor sobre a prática não se restringe a uma teorização com o objetivo de apenas explicar ou compreender a prática. Propõe que essa reflexão deve ser crítica, pois do contrário a teoria pode virar um discurso "vazio" e a prática um mero "ativismo".

Portanto a teoria tem como função oferecer subsídios de análise e compreensão da realidade social, organizacional, histórica e cultural e de si próprios como seres sociais, que como docentes podem intervir nessa realidade transformando-a. O professor formador que toma como alvo um processo de 
aprendizado baseado na construção de saberes por parte do aluno (professor em formação), que estimula a perspectiva reflexiva, de crítica e de pesquisa acerca de sua ação, se faz responsável por estratégias que favoreçam esse aprendizado. Partindo do contexto vivo e real, percebe a necessidade de se reconhecer, não apenas como transmissor, mas como produtor de conhecimento.

Foi com satisfação que percebi que a maioria dos professores investigados identifica a importância da pesquisa para o ensino que desenvolvem. Demonstram valorizar investigações sobre formação e profissão docente, sobre ensinar e aprender em qualquer nível de ensino. Mas consideram importante o conhecimento sobre os sujeitos do ensinar e do aprender e as implicações dessa perspectiva na profissão docente.

Mencionam suas dificuldades e tensões, mas revelam um compromisso com o que fazem. Sentem-se compromissados com a formação de seus alunos e encontram sentido na sua profissão. Reconhecem que melhores condições de trabalho favoreceriam seu desenvolvimento profissional docente; mesmo assim, lutam por elas no posto que decidiram estar; não abandonam o barco, são timoneiros de suas escolhas e crenças profissionais.

\title{
6.3 A aula: o lócus da relação teoria e prática
}

\begin{abstract}
Um professor vai começar a sua aula. Evidentemente, isto não é nada de especial, não é um acontecimento. Passa-se a mesma coisa cem vezes no mesmo edifício. Mas pensar assim não chega para dissipar uma inquietação que pode ir até a angústia. Que venho eu aqui fazer? E que vêm fazer eles, eles todos e cada um por seu lado? (GUSDORF, 2003, p. 56).
\end{abstract}

A aula é o espaço pedagógico em que professores e alunos trabalham, mantêm uma relação pedagógica de cunho dialógico, constroem conhecimentos e avaliam. É um espaço de configuração e reconfiguração de saberes e fazeres na ótica do diálogo entre os diferentes saberes, tendo em vista a pluralidade e a autonomia dos sujeitos. Tardif e Lessard (2005, p. 35) esclarecem que "a docência é um trabalho cujo objeto não é constituído de matéria inerte ou de símbolos, mas de relações humanas com pessoas capazes de iniciativas e dotadas de certa capacidade de resistir ou de participar da ação dos professores".

A aula transforma-se em espaço de vida coletiva, um espaço de relações originais, em que os laços entre alunos e professores com o conhecimento são 
acentuados. Nesse sentido, as aulas observadas foram interativas, ficando evidenciada a relação entre estudantes e docentes. Até mesmo nos intervalos foi possível verificar que alguns ainda permaneciam em volta dos professores, sanando suas dúvidas e discutindo sobre as questões do trabalho ou de alguma atividade.

$\mathrm{Na}$ observação das aulas da docente P1, percebi a utilização sempre da mesma sala de aula, que está localizada no primeiro piso do prédio designado para os cursos de licenciatura. É ampla, com capacidade para 65 estudantes, possui espaço que permite a professora se locomover tranquilamente. Nessa sala, o quadro branco ocupa toda a parede, possui uma mesa para a professora no canto oposto à porta de entrada, que não é utilizada por ela. Ao chegar à sala, sempre pontualmente, coloca o seu material nas primeiras classes. Em frente ao quadro estão dispostas classes em fórmica branca, leves, de fácil locomoção, enfileiradas uma atrás da outra. A iluminação artificial propicia um ambiente com luminosidade suficiente para a sala de aula. Possui ar-condicionado central. É uma sala de aula convencional.

Essa turma é composta de 35 alunos. Durante as aulas observadas, havia em média a ausência de cinco alunos. Dos estudantes matriculados, 20 estavam na faixa etária entre 19 e 25 anos de idade, e 15 com mais de 30 anos de idade. Poucos chegam antes do horário.

A impressão que tive é que os docentes estavam cientes dos atrasos e aproveitavam os minutos iniciais para organizar o material, retomar combinações anteriores, dar avisos etc.

A professora $P 1$ chega pontualmente na sala de aula, coloca o seu material nas classes da primeira fila. Cumprimenta sorridente e em um tom agradável. Comenta com os alunos que após diversas aulas estarão sentados e colocados como em uma aula tradicional. Logo após, começa a escrever no quadro os objetivos da aula: socializar as práticas educativas vivenciadas e realizar autoavaliação. Dar e receber feedback e colocar em observação o texto que deverá ser lido para a próxima aula. (Trecho do diário de campo,maio 2013, P1 Didática-OTP)

Esse ritual ocorreu em todas as aulas que observei dessa docente. Quando questionada na entrevista como ela organiza o seu planejamento, informou: 
Temos aquele cronograma que é organizado no início do semestre, com todo o conteúdo programático, com todas as aulas e atividades que vamos desenvolver durante o semestre. Para mim é importante ter, pois assim organizo todas as aulas e distribuo os conteúdos. Nunca vou para a aula sem planejamento anterior, me sento mais segura, além disso os alunos merecem respeito. Como posso falar sobre a importância do planejamento se não faço? Os alunos me olham como exemplo. Eu preciso saber como a aula irá acontecer. Organizo tudo, chego no horário, converso um pouco com eles, retomamos combinados. Organizo com eles a sala. E sabemos que mesmo que o planejamento esteja bem organizado, muitas vezes não acontece como pensamos. (P1)

Acredito que quando um docente formula mudanças no seu plano de ação e nas suas decisões práticas, ele manifesta indicativos de rearticulação de saberes que são resultados da reflexão e da compreensão da sua prática.

P1 é uma professora muito organizada. Em sua pasta, possui a ficha de cada aluno com seus dados pessoais (preenchida por eles no primeiro dia de aula), um contrato pedagógico que foi acordado por toda turma, os planos de aula, roteiros para as atividades, planilhas com as notas dos trabalhos e provas e, por fim, a chamada. Quando entrevistada, P1 enfatizou a necessidade dessa organização, pois quando, por algum motivo, os alunos não entregavam as atividades, ou por não estarem em aula pediam prazos, a professora mostrava a eles o contrato.

Ressalta-se ainda a preocupação que ela tem de mostrar pelo exemplo o sentido que dá ao seu conteúdo, ao planejamento do ensino. Sua expectativa é de que os alunos percebam, na prática, aquilo que ela procura evidenciar no discurso: a importância do planejamento na ação educativa. Novamente, temos o exemplo de uma didática viva, em que a forma do trabalho do professor quer se constituir ou reforçar o conteúdo curricular de aprendizagem. Também a dimensão dos valores parece estar em jogo, e seu depoimento explicita como a estratégia do contrato tem sido utilizada.

É uma maneira de responsabilizá-los, é fácil colocar a culpa no grupo, ou simplesmente pedir mais prazo, o contrato serve para que eles e eu saibamos o que irá acontecer em cada aula, cada atividade, assim eles podem se organizar. Cada final de aula relembro os combinados. (P1)

Para Zabala (1998), a função básica dos contratos de trabalho consiste em facilitar a tarefa dos professores ao propor a cada aluno as atividades de aprendizagem apropriadas a suas possibilidades e seus interesses. $\mathrm{O}$ trabalho do 
professor está centrado em determinar quantas e quais são as tarefas a serem realizadas e também o nível de profundidade.

A diretividade do professor no processo de ensinar e de aprender é condição para não cair em um lassez-faire, que acaba funcionando como uma relação autoritária: a vontade de todos tende a ser a vontade de um ou de alguns que assumem um papel dominador/centralizador.

A não possibilidade de separar a figura do professor como pessoa e profissional é justificada por Nóvoa (2007) p. 31), quando diz que "ser professor obriga a opções constantes que cruzam nossa maneira de ser com a nossa maneira de ensinar, e que desvendam na nossa maneira de ensinar a nossa maneira de ser". A identidade do professor define-se num equilíbrio entre as características pessoais e profissionais, portanto as suas ações traduzem a plenitude de sua pessoa, da mesma maneira que a compreensão da humanidade do docente contribui para a compreensão da prática profissional.

Quanto às condições objetivas, a sala de aula era adequada ao tamanho da turma, o que propiciou intercâmbios socioculturais e fortaleceu os significados dos próprios participantes na ação docente. No que concerne à utilização de recursos de ensino, as aulas desenvolveram-se com a utilização da técnica de exposição oral e recursos tecnológicos, mais especificamente o projetor multimídia. Como explicita Araújo (2006, p. 15), “os métodos, as técnicas e as tecnologias educativas, apesar de serem um objeto teórico que se explicita projetivamente num planejamento de ordem institucional e professoral, concorrem para o processo de ensino, viabilizando-o".

Durante a exposição, os alunos estavam em silêncio, e percebi que prestavam atenção ao que estava sendo explicado. A docente estabeleceu relações entre o tema da aula e o contexto social e acadêmico, trazendo inclusive exemplos do cotidiano dos alunos. A aula transcorreu dessa forma até o intervalo. Foi possível observar que essa aula expositiva enfatizava o conteúdo disciplinar, mas também ficou clara a intenção da docente em trazer para a realidade da escola. Utilizava exemplos e solicitava que os alunos participassem. Durante todo o tempo da aula, seis alunos participaram. Ao fundamentar sua ação pedagógica na aula (ações e estratégias), a docente P1 expõe as razões pelas quais escolhe as aulas expositivas. 
Eu sempre prefiro trabalhar com aulas expositivas, pelo menos um período da aula, então fico fazendo movimentos que motivem os alunos a participarem. Utilizo exemplos, ou solicito que eles exemplifiquem a partir da realidade da escola, pois grande parte dos alunos já trabalha, ou trabalharam na escola. Assim a aula fica bem interessante, eles ficam atentos e consigo trabalhar de forma mais profunda, conceitos, teorias etc. Eles também gostam muito das aulas assim. (P1)

Nesse momento, acredito ser interessante levantar 0 seguinte questionamento: o que leva os alunos e a docente a preferirem aulas expositivas? Sabe-se que o fato de utilizar a aula expositiva como uma estratégia metodológica não caracteriza como tradicional a forma da docente ensinar, no entanto parece que no momento histórico que estamos vivendo seria interessante propor ações que estimulassem os alunos a desenvolver outras habilidades cognitivas. O que os leva a pensar e agir como protagonistas do processo de ensino e aprendizagem? Seria valorizar o contexto social em que vivem e inserir a dúvida como um princípio pedagógico? De qualquer forma, as aulas expositivas fazem parte da tradição acadêmica e dão uma contribuição importante. Mas muito há ainda para investir e pesquisar sobre novas possibilidades de aprender e ensinar.

A docente P6 realizava todas as suas aulas em uma sala que funciona como o Laboratório de Aprendizagem. Trata-se de uma sala com seis mesas hexagonais e cadeiras em volta, lugares suficientes para o grupo de alunos. Tinha disponíveis vários materiais didáticos, jogos, livros etc. Não possuía quadro para anotações. Ela sempre utilizava o projetor. As aulas tinham uma organização diferenciada. Os alunos chegavam ao mesmo ritmo que os das outras turmas, poucos pontualmente. No diário de campo, recupero parte da aula para explicitar.

A professora chega ao laboratório, local onde são realizadas essas aulas de Didática-OTP, pontualmente. Organiza o local para colocar o computador, o projetor. Aguarda a chegada dos alunos e inicia a chamada e quando os alunos estão ausentes ela comenta "Essa disse que não viria hoje, mandou recado pelo Face, esse vai chegar atrasado, também postou no Face". Pergunta para todos como passaram a semana, conversam um pouco sobre isso e retoma alguns aspectos que ficaram abertos na aula passada. Um aluno comenta sobre os textos que leu e o quanto está sendo interessante poder fazer os comentários com os colegas. Os textos são sobre planejamento. A professora questiona o grande grupo quanto à realização da leitura dos textos. Boa parte não havia lido. Ela faz um comentário e liga o projetor, aparece um quadro colorido com três palavras: epistemologia, professor e aluno. Estimula os alunos a pensarem sobre o quadro, levando-os a se posicionarem. À medida que eles vão aos poucos 
interagindo, ela vai esclarecendo os conceitos. (Trecho do diário de campo, set. 2013, P6 - Didática-OTP).

Embora a docente P6 tenha demonstrado nessa situação a capacidade de trabalhar com imprevistos, sem tornar a aula um evento improvisado, instigando os alunos a partir de suas experiências, outro encaminhamento poderia ter sido tomado? Poderia ter proposto a leitura do texto em sala, em grupos ou individuais? Fui anotando essas reflexões durante minhas observações, num diálogo comigo mesma. Fiquei imaginando como seria rico transformá-las numa roda de conversas, com fins formativos. Como poderíamos aprender uns com os outros!

É indiscutível que nas aulas observadas foram sinalizadas preocupações em construir uma relação pedagógica com os alunos, respeitando a heterogeneidade da turma. A análise dos dados permite afirmar que as aulas observadas apresentaram evidências de articulação entre teoria e prática, ensino e pesquisa, procurando aproximar o professor pesquisador em formação das questões de seu campo de trabalho, muito embora tenha havido centralidade no contexto da educação básica, objeto da disciplina.

Observei ainda que o envolvimento das professoras em processos reflexivos propiciou uma nova maneira de planejar, ensinar, aprender, pesquisar, avaliar e relacionar-se com os alunos. Significa que a inovação só se desenvolve dentro das instituições educativas se for concretizada no decorrer da aula com professores e alunos em processo colaborativo. Os professores não são técnicos que executam instruções e propostas elaboradas por outros.

Foi possível registrar a posição da docente $\mathrm{P} 2$ com relação à relevância da disciplina de Didática-OTP, quando afirmou:

Nessa disciplina tenho bastante cuidado, não só na questão do planejamento, mas com a formação dos futuros professores. Eles têm de conhecer e praticar os fundamentos teóricos e metodológicos para poder se tornar bons professores. (P2)

Nas observações das suas aulas, percebi que esse cuidado estava bastante presente. Quando chegávamos à sala de aula, o quadro já estava organizado, com todos os itens que seriam tratados, objetivos da aula e atividades que seriam 
desenvolvidas. Essa docente, durante todas as aulas observadas, mantinha uma relação muito próxima com os alunos.

Ao entrar na sala de aula, já havia alguns alunos organizando as classes como de costume em forma de "U". A docente P2 estava em sala organizando os materiais para serem trabalhados. O quadro estava com o planejamento da aula. Iniciava com um pensamento sobre educação e era seguido pelos objetivos da aula e as atividades que seriam desenvolvidas. Lembretes com datas das entregas dos trabalhos e encaminhamentos para a aula seguinte. O que me chamou atenção foi que a docente não havia escrito no quadro enquanto estávamos aguardando a chegada dos alunos. (Trecho do diário de campo, maio 2013, P2 - Didática-OTP)

Esse fato indica que as questões metodológicas não atuam no vazio nem têm um fim em si mesmas. Na entrevista, a docente me relatou que escrevia no quadro antes do início do horário da aula para que não perdesse tempo em organizar o quadro. Como os alunos vão chegando em diferentes horários, serve para que eles se organizem, se acomodem e não fiquem perdidos com relação ao que iria acontecer depois.

A aula é construída por meio do protagonismo de professores e alunos. Todos são personagens e têm um papel a desempenhar. Professores e alunos são sujeitos históricos no processo didático e portadores de uma prática social a ser problematizada, compreendida e sistematizada coletivamente. As aulas observadas centraram-se na práxis social de ambos: docentes e estudantes. Na realidade, os docentes e os estudantes desempenharam um conjunto de atividades envolvendo exposição oral, discussões de aprofundamento orientadas por questões que direcionavam para a inclusão de outras perspectivas de análise e avaliação do que foi realizado nas aulas.

Com relação entre seu plano de ensino e sua prática pedagógica cotidiana, assim se manifestou:

Eu sempre submeti a minha proposta aos meus alunos, e a minha experiência tem apontado que isso é bastante positivo, pois eles se sentem participantes da construção da proposta, é claro que faço acomodações, negociações. (P4)

Eu programei as minhas aulas pensando nos diversos encontros que teríamos. O foco é o espaço e o tempo, então eu tinha que possibilitar que eles vivessem essa experiência, não poderia só falar sobre. E para que eu pudesse possibilitar 
que eles inserissem essa noção de espaço e tempo no seu raciocínio eu precisava mexer com espaço e tempo, então um bom caminho era ter aulas em espaços diferentes, na sala de aula tivemos só cinco aulas durante todo o semestre. Procurei na universidade espaços que poderia utilizar, de forma premeditada, pois cada espaço remetia um tipo de leitura. Como por exemplo: a biblioteca, laboratórios de Pedagogia e o da História e Geografia, e a escola. (P3)

A aula parece ser compreendida como espaço e tempo determinados, em que a professora e os alunos realizaram uma série de ações e interações, tais como apresentar e discutir sua proposta de trabalho logo no início da aula. Esse fato denotou uma preocupação com a participação do aluno na revisão dos caminhos traçados para o desenvolvimento do plano de ensino. O trabalho pedagógico coletivo foi uma constante nas aulas observadas, uma vez que os docentes fortaleceram as observações e as sínteses elaboradas pelos grupos.

A docente procurou atender aos interesses dos alunos e construir um espaço favorável para o desenvolvimento do processo educativo. A prática de compartilhar a responsabilidade pela organização do trabalho pedagógico pareceu bastante positiva.

Quando questionada sobre o assunto durante a entrevista, a docente afirmou:

O refletir sobre sua prática pedagógica, é necessário realizar esse movimento, pois à medida que coloco em discussão com os alunos reflito sobre as questões, e no diálogo com eles aprendo a ver as coisas de diferentes formas. (P6)

A organização da aula, partindo da prática social do aluno, representa a valorização da percepção que este traz do tema de estudo, a partir de suas experiências, cuja prática social, ao ser problematizada, possibilitou ao docente construir novas sínteses e reelaborá-las. Esse processo só foi possível por meio de situações organizadas pelo professor e que serão determinantes na construção do conhecimento, como lembra Anastasiou (2005). A abertura ao diálogo e a sensibilidade do professor são elementos importantes na constituição da relação pedagógica em sala de aula. Para Freire (1996), diálogo promove a experiência da abertura como experiência fundante do ser inacabado, que terminou por se saber inacabado. É a abertura ao outro, em busca de respostas ao problematizar questões relevantes à formação dos futuros professores, que possibilita ao formador perceberse inacabado. A prática dialógica articula-se à sensibilidade. 
A aula constituiu-se em torno de atividades acadêmicas mediadas pela ação das professoras, que fizeram exposição dialogada, organizaram ideias, indagaram, buscaram caminhos alternativos e formas diversificadas de ensinar, retificaram concepções, corrigiram falhas, esclareceram dúvidas, instigaram os alunos a construir outras formas de conhecer e interpretar o trabalho docente, argumentaram, contra-argumentaram, avaliaram. A aula expositiva dialogada como técnica de ensino aproximou o aluno do trabalho docente e fortaleceu a relação teoria e prática na maioria das vezes.

Nas aulas observadas, verifiquei que todos os docentes estabeleciam uma relação de parceria com os seus alunos, em geral de forma harmoniosa. Essa condição foi percebida na ação de P1, através do contrato pedagógico, realizado no início do semestre; nos outros, a partir de combinações estabelecidas no começo da aula e/ou no final, sempre respaldados pelo planejamento do semestre, que chamam de cronograma.

Segundo Goffman (2003) no espaço da sala de aula descortina-se um processo de interação face a face que ocasiona uma influência recíproca dos indivíduos entre si, em suas ações uns com os outros; interações proporcionadas pela presença física, pela corporeidade, em se tratando da educação presencial. $\mathrm{O}$ autor compara a vida em sociedade à atuação de atores num palco, analogia adequada à sala de aula, o palco da docência. $\mathrm{Na}$ afirmativa da docente $\mathrm{P} 1$, aparece claramente essa concepção:

A aula é um momento mágico. Eu comparo a um grande ato, onde eu me
preparo, eu entro em cena, com todas as minhas falas, com os meus trejeitos e
quando eu entro lá me deparo com o impensado e aí eu modifico, eu adapto, eu
improviso. Atendo a demanda do aluno, busco novas formas e às vezes o que
eu orquestrei não funciona tão bem, outras vezes funciona tão bem que eu não
consigo levar até o final. E que por mais que a gente se planeje o aluno traz
demandas que nós não havíamos pensado, às vezes boas, às vezes ruins, mas
para mim é isso que traz o fascínio da aula, é a gente não saber o que irá
acontecer. É um momento de muita aprendizagem para mim e para eles. (P1)

A capacidade de adaptação aos momentos imprevistos da aula faz parte dos saberes docentes e reafirma que somos atingidos pelos comportamentos daqueles com os quais convivemos. Passamos a assimilar regras sobre o comportamento do grupo, sem que necessariamente tenhamos plena consciência disso. As diferentes equipes de atores sociais representam papéis para plateias distintas, em que 
reforçam sua linha de atuação e defendem sua face. Nas entrevistas, ficou manifesta essa ideia, no sentido de que cada turma é diferente da outra, os alunos se agrupam de outra forma, trazem outras demandas, possuem outras expectativas. O mesmo conteúdo, trabalhado em diferentes turmas, desencadeia aulas diferentes. Para exemplificar, utilizo a contribuição da docente P6:

Muitas vezes, uso o mesmo texto na disciplina e à medida que vamos
trabalhando a partir do olhar do aluno, começo a enxergar coisas que nunca
havia visto, mesmo que já tenha lido o texto inúmeras vezes. Eles conseguem
enxergar coisas maravilhosas porque eles trazem a realidade deles, os saberes
que eles construíram ao longo das suas vidas. É muito interessante isso, e eu
acabo alterando alguns pontos da aula para contemplar as contribuições deles.
(P6)

A professora divide o tempo da aula em dois momentos que se interpenetram e se completam: um destinado a discutir assuntos do cotidiano e o outro voltado ao conteúdo da aula. Mesmo fragmentados, os períodos mais longos são destinados à exposição do assunto. No tempo destinado para a conversa informal, o ritmo da aula é mais dinâmico, favorece a integração ativa dos estudantes, oportunizando um clima mais descontraído entre a turma e a docente. Na entrevista, P6 informou que utiliza esse espaço informal para conhecer melhor os alunos, mas que também possibilita conhecer o nível de informações e atualização dos estudantes.

A docente P2 diz: "meus alunos sabem que nas minhas aulas nos primeiros minutos discutimos alguma coisa relacionada à educação, sempre trago algo que saiu no jornal, revista ou outro meio de comunicação". Em uma aula que observei, ela trouxe o recorte da Zero Hora com a campanha que a RBS estava realizando. Foi um debate muito rico, discutiram o significado e as contribuições, ou não, que seriam desencadeadas pela campanha.

A docente P2 trouxe hoje para o início da sua aula o jornal Zero Hora, conversou com os alunos, perguntou se eles sabiam que naquele dia estava iniciando a campanha da RBS, se eles haviam lido alguma coisa a respeito. Um aluno respondeu rapidamente que sim e que considerava bem interessante, outro disse que não concordava porque considerava simplesmente um marketing. A professora pediu licença e solicitou que primeiro eles lessem sobre o assunto para que depois trouxessem as suas opiniões, para não ficar uma discussão vazia. Distribuiu cópias xerocadas do artigo para lerem em pequenos grupos. (Trecho do diário de campo, maio 2013, P2 - Didática Geral-OTP) 
Outra docente utiliza o início da aula para conversas informais. Com relação à organização do tempo, as aulas, em geral, são divididas em três momentos: a conversa informal; o conteúdo a ser trabalhado; e, após o intervalo, o trabalho dos alunos em pequenos grupos, sempre com atividades diferenciadas, com o objetivo de articular os conceitos aprendidos em aula e a prática.

As aulas da docente P6 iniciam sempre pontualmente, chega sempre antes para
abrir a sala. Poucos alunos já estão em frente à porta. Ela abre a sala e os
estudantes vão se organizando dentro da sala. Como escrevi anteriormente, é
um laboratório do Curso de Pedagogia, com mesas hexagonais e sem quadro
branco. Enquanto ela organiza o material que os alunos irão utilizar hoje, vai
conversando com eles, sobre como passaram a semana etc. uma conversa bem
informal. Logo em seguida inicia a chamada e introduz a discussão.
[...]
Após o intervalo os estudantes em pequenos grupos tinham como tarefa
construir um instrumento de avaliação, conteúdo trabalhado pela docente
durante a parte expositiva. Apresentou os conceitos e concepções de avaliação,
que geraram muitos questionamentos, após os tipos de avaliação, tipos de
questões e critérios de correção das avaliações. Após o intervalo, sugeriu que a
turma se dividisse em pequenos grupos, o que foi realizado pela turma
rapidamente. Sem tensão, eles mesmos se organizaram e iniciaram a atividade.
Não houve tempo para concluir. A professora combinou que fariam na aula
seguinte. (Trecho do diário de campo, set. 2013, P6 - Didática-OTP)

O trabalho em grupo faz parte das aulas dessa docente, que divide as suas aulas em momentos variados, envolvendo trabalhos individuais, seminários, encenações, aulas expositivas. Em seu depoimento, ela revela ser adepta das novas tecnologias e utiliza todas disponíveis pela instituição e leva sempre o seu notebook. A sala de aula é organizada para atender à estratégia metodológica escolhida pela docente, normalmente um semicírculo. Como ela afirma em entrevista: "[...] a sala de aula organizada em semicírculo propicia que todos os alunos se enxerguem, olhos nos olhos, conseguem visualizar quem está falando. Acredito que os aproxima, favorece as relações interativas entre nós" (P2).

Utilizar essa estratégia metodológica não é simplesmente dividir a turma em pequenos grupos e distribuir tarefas. De acordo com Anastasiou (2005, p. 75), as estratégias grupais são um ato que gera aprendizagem social e necessita da mediação do outro como facilitador do processo. Segundo a autora, esse outro pode ser o professor, o colega, um texto, um vídeo, um caso a ser solucionado ou um tema a ser debatido. Esses tipos de atividades devidamente desenvolvidos auxiliam 
no desabrochar da inteligência relacional. Ela salienta ainda que o trabalho em grupo é diferente de fazer parte de um conjunto de pessoas, sendo fundamental a interação, o compartilhar, o respeito à singularidade, a habilidade de lidar com o outro, incluindo as suas emoções.

Confesso que não registrei nas minhas observações nenhuma tensão quando os estudantes se colocavam em grupos, mesmo aqueles em que os professores designavam. Mas o que me chamou a atenção é que durante as observações também não houve explicação alguma sobre como se constituíam os grupos para desenvolver as atividades. Nas entrevistas, questionei os docentes por que eles não explicavam como se faz um trabalho em grupo. Todos foram unânimes em dizer que os alunos sabiam o que significava. Acredito que esse seja um ponto no qual verifico contradição. Afinal, por mais que os estudantes já tenham trabalhado em grupo, por se tratar de uma disciplina de didática, os docentes deveriam trabalhar o conceito e a organização da estratégia, para que os alunos compreendam seus fundamentos.

De acordo com Anastasiou (2005, p. 77),

Inicialmente, até que os alunos se soltem em atividades grupais, as
contribuições de cada participante podem ficar mais restritas às discussões
do pequeno grupo, expondo menos cada aluno. Quando ainda se mantém
uma inibição no grupo no momento de socialização da síntese, costuma
ocorrer indicação pelo próprio grupo, de colegas que já trazem
desenvolvidas as habilidades de exposição oral.

Durante as observações, verifiquei que os trabalhos em grupos eram desenvolvidos exatamente como o exposto pela autora, o que sinalizou que a prática dos docentes, assim como afirma Bourdieu (1989) em sua teoria da prática, está incorporada e naturalizada em suas práticas pedagógicas como algo autoevidente para a dinâmica do trabalho em grupo. Explicando melhor, os docentes pressupõem que os alunos conhecem, na prática, a dinâmica e a lógica envolvidas no trabalho em grupo, e por isso entendem a desnecessidade da articular reflexivamente uma explicação sobre a dinâmica do trabalho em grupo.

Percebi nas observações que os docentes deixavam claros os objetivos dos trabalhos, as etapas e as formas de encaminhamento dos processos. Ficavam disponíveis, atentos e circulavam pelos grupos, acompanhando os processos e os grupos na sala de aula. 
Os alunos, distribuídos em pequenos grupos, discutiam o texto. Alguns gesticulavam, falavam um pouco mais alto. Outros consentiam com um balançar de cabeça [...] quando prontos para realizar a síntese ao grande grupo, a professora perguntou: "Grupo 1, quem irá se dirigir ao grande grupo?" Todos os colegas disseram em uma só voz "O fulano". Era o mais falante do grupo, desinibido. (Trecho do diário de campo, abr. 2013, P4 - Didática-OTP)

Há nessa aula, assim como em outras observadas, um forte estímulo motivacional e ao mesmo tempo uma presença e uma mediação por parte do docente, que está efetivamente e afetivamente muito próximo dos estudantes, criando um clima de confiança na turma. A participação é bastante significativa e corresponde à grande maioria da turma; os alunos questionam, trazem exemplos, apresentam pontos de vista.

Nos depoimentos dos professores, foi possível perceber que esses docentes planejam as suas aulas, que procuram fazê-las, de maneira geral, dinâmicas e contextualizadas. Contudo vale lembrar que, de certo modo, a força do habitus e da “institucionalização", conceitos de Bourdieu (1983), acaba regulando os indivíduos e cristalizando as suas ações.

\subsection{O estudante: protagonista da formação}

Observei nas aulas que os estudantes adotam diferentes posturas, dependendo da situação de aprendizagem em que eram colocados. Enquanto os docentes faziam as suas exposições, ficavam com uma postura de escuta, observação e atenção, registrando as anotações, mas também de manifestação sempre dirigida à professora. Em alguns momentos, respondiam às perguntas ou justificavam suas respostas. Nas aulas observadas, houve em todas as turmas intervenções dos alunos em diversos momentos, assim como a troca entre os estudantes e seus colegas. Acredito que a forma como os docentes organizavam as suas ações possibilitava essas interações.

Os estudantes, na grande maioria, demonstraram que gostam de aulas expositivas. Ressaltaram, no entanto, que o professor deve estabelecer relações entre a teoria e a prática, envolvendo o conteúdo que está sendo trabalhado. Freire e Shor (2000) enfatizam que a aula expositiva por si só não é tradicional, nem uma pura transmissão de conteúdos. O professor deve fazer a aula ser interessante, proporcionando aos seus alunos a participação. Ainda em Freire (1996), há a 
concepção de que o bom professor é o que consegue, enquanto fala, trazer o aluno até a intimidade do movimento do seu pensamento. Nas entrevistas, os estudantes demonstraram que consideram significativas as práticas realizadas em sala de aula.

A professora trabalhava textos da atualidade, vídeos, seminários. A parte prática
foi onde nós tivemos que planejar uma prova com o conteúdo que foi aplicado
por ela no semestre, tivemos que fazer a correção e avaliar. Também realizamos
a apresentação de uma aula diferenciada para nossos próprios colegas, onde
escolhíamos o tema, planejar e a ação e realização da docência. (E1)

A professora utilizou-se de metodologias diversificadas, como seminários avaliativos ou não, a partir de um roteiro de leitura distribuído para os acadêmicos, em que todos discutiam questões presentes nele ou fora, preenchendo o planejamento vazio da disciplina e daquela aula [...] trabalhos de análises de atividades de educandos do ensino fundamental, como o caso do diagnóstico do ditado, como de livros didáticos, um dos focos da disciplina, culminando no trabalho teórico-prático, apresentado em grupo no final do semestre, reunindo uma síntese da aprendizagem do semestre, questionamentos gerais e reflexões da sua aplicabilidade. (E4)

Os depoimentos parecem indicar que os estudantes percebem a articulação entre o ensino e a aprendizagem a partir da experiência que vivenciam durante a sua formação através das atividades práticas.

Em todas as suas manifestações, afirmaram que tiveram durante as disciplinas apropriação de conhecimentos a partir da reflexão e das discussões de situações e problemas que vivenciavam no cotidiano das escolas que estavam inseridos:

Em muitas aulas, tive a sensação que a professora estava falando para mim. Muitas vezes tinha lá na escola alguma questão a ser solucionada, e ela acabava falando em aula. "Ah! Um exemplo é com relação ao trabalho coletivo, pensar com os outros colegas, preparar atividades em conjunto". Aprendi isso e lá na escola consegui realizar, foi muito bom! (E5)

[...] a disciplina e a professora apresentaram um leque de oportunidade para ousar no ensino da língua portuguesa. Desse modo, o mais aplicável nesse período, com meu $4^{\circ}$ ano, foi a reflexão das regularidades e irregularidades da ortografia. Saliento, no entanto, que a disciplina abordou variação linguística, produção textual e leitura, igualmente importantes. (E4) 
Durante o período das observações e nas entrevistas ficou manifesto pelos estudantes o quanto eles valorizam as atividades, nas quais percebiam a relação entre teoria e prática.

Aprendi nesta disciplina a organizar um plano de aula. Isso eu tinha visto no magistério, mas aqui eu aprendi a organizar a aula, no tempo e no espaço. Vivenciei a construção dos planos de aula, não só o meu, mas também dos meus colegas, e pude saber como escolher os conteúdos a serem trabalhados. Foi uma experiência significativa. (E6)

No decorrer desse semestre, com a disciplina de Metodologia de Ensino de Ciências e Biologia, pude aprender várias formas diferentes de utilizar um conteúdo, podendo cativar o aluno e manter a atenção dele na aula. Uma aula bem programada, uma aula construída, pensando no perfil de cada turma é uma aula bem executada. Com certeza, os alunos irão aprender muito mais. (E9)

Outro aspecto que os estudantes consideraram significativo para a sua formação está relacionado à construção e à utilização de recursos didáticos. Em algumas entrevistas das disciplinas de Didáticas Específicas, foi manifestado o interesse na construção dos recursos didáticos. Talvez se deva ao fato de estar relacionada a conteúdos mais específicos do curso em que estão inseridos; por já possuírem conhecimento na área, os estudantes sentem a necessidade de se instrumentalizar para a sua prática docente.

Nas entrevistas, solicitei que organizassem por ordem de importância (de 1 a 7) aqueles aspectos que maior significado têm para eles no estudo das disciplinas que realizaram. Os resultados podem ser visualizados no quadro a seguir. 
Quadro 3 - Aspectos significativos na prática dos docentes investigados a partir do olhar dos estudantes

\begin{tabular}{|c|c|c|c|c|c|c|c|}
\hline Identificação & $\begin{array}{c}\text { Relação } \\
\text { teoria- } \\
\text { prática }\end{array}$ & $\begin{array}{l}\text { Ensino- } \\
\text { pesquisa }\end{array}$ & $\begin{array}{l}\text { Relação } \\
\text { professor- } \\
\text { aluno }\end{array}$ & $\begin{array}{l}\text { Organização } \\
\text { do trabalho em } \\
\text { sala de aula }\end{array}$ & $\begin{array}{l}\text { Construção } \\
\text { de recursos } \\
\text { didáticos }\end{array}$ & $\begin{array}{l}\text { Concepção de } \\
\text { conhecimento }\end{array}$ & $\begin{array}{c}\text { Formas de } \\
\text { avaliação }\end{array}$ \\
\hline E1 & 1 & 5 & 3 & 4 & 7 & 2 & 6 \\
\hline E2 & 1 & 2 & 3 & 5 & 4 & 6 & 7 \\
\hline E3 & 3 & 1 & 2 & 4 & 6 & 7 & 5 \\
\hline E4 & 2 & 5 & 1 & 6 & 7 & 3 & 4 \\
\hline E5 & 1 & 3 & 2 & 4 & 7 & 5 & 6 \\
\hline E6 & 1 & 2 & 3 & 4 & 6 & 5 & 7 \\
\hline E7 & 2 & 3 & 1 & 4 & 6 & 5 & 7 \\
\hline E8 & 3 & 1 & 2 & 5 & 7 & 5 & 6 \\
\hline E9 & 2 & 1 & 3 & 4 & 5 & 6 & 7 \\
\hline E10 & 1 & 3 & 2 & 4 & 7 & 6 & 5 \\
\hline E11 & 2 & 1 & 3 & 5 & 7 & 5 & 6 \\
\hline E12 & 1 & 2 & 4 & 3 & 7 & 5 & 6 \\
\hline
\end{tabular}

Fonte: a autora (2014)

Observando o quadro acima, pode-se inferir que, dos 12 estudantes, dez destacam a relação teoria-prática, ensino-pesquisa e professor-aluno como as mais importantes para a sua formação. Os estudantes destacaram, ainda, que os docentes investigados propiciam a articulação entre os saberes, estabelecendo a relação entre teoria e prática.

Outro aspecto a ser levantado em relação ao quadro acima é o fato de a grande maioria dos alunos classificar a construção de recursos didáticos como menos significativos. O que os motivou a assumir essa posição num contexto de tanta exploração midiática? Será o fato de eles já terem esses conhecimentos? Ou será que os professores pouco trabalharam esse aspecto?

Durante as entrevistas, alguns dos estudantes - em especial os do curso de Biologia - manifestaram que quando haviam realizado a matrícula na disciplina de Didática Geral-OTP não a consideravam importante, mas durante o semestre perceberam o seu significado na formação como professores de Ciências e Biologia.

Disseram eles:

Sempre pensei que essas disciplinas pedagógicas não faziam muito sentido no curso, ouvia colegas falarem bem delas, mas eu acabava sempre deixando para trás. Hoje vi que é muito importante, me ensinam a ser professor, mexeram bastante comigo. (E6) 
Não fiz magistério, e não tinha nem ideia que para organizar uma aula seria tão complexo. Nesta disciplina aprendi bastante em relação a isso. Mas também aprendi que para ser professora tem que ter comprometimento, responsabilidade, fazer com que o aluno tenha vontade de participar das aulas, tenha vontade de ensinar. (E2)

Nas entrevistas, quando solicitei que informassem o que gostariam que fosse diferente, caso recomeçassem o curso, em relação às disciplinas pedagógicas, os alunos de Biologia manifestaram que sentem falta de mais disciplinas pedagógicas e mais contato com a realidade da escola. Verificando no Projeto Pedagógico do curso, constatei que a disciplina investigada é a única específica de metodologia do ensino em Biologia e Ciências.

Durante as entrevistas, os estudantes mencionaram essas disciplinas como experiências fundamentais às suas formações.

Acredito que a análise de livros didáticos é importante, não parecia, mas não é fácil apreciar uma obra, não é um exercício comum nas licenciaturas. É a segunda disciplina que propõe isso (a primeira foi com a mesma professora, mas com o foco na oralidade), porque é dever do professor escolher, com o seu grupo, um material de trabalho para três anos. (E9)

Para mim foi a elaboração da prova, foi muito importante, pois tivemos que planejar as questões conforme o conteúdo, questões de diferentes tipos e com notas diferenciadas. (E10)

Nas aulas observadas, pude presenciar diversos momentos nos quais os docentes proporcionavam atividades de modo que os estudantes eram colocados como protagonistas.

Ao conviver com esse professor, aprendi como é o cotidiano da sala de aula, os dilemas encontrados e as soluções que podemos tomar, a postura correta diante dessa ambiguidade que é a sala de aula. (E3)

Esse professor me ensinou a utilizar metodologia da pesquisa para resolução de problemas. Também vou usar em sala de aula. É importante colocar os meus alunos em contato com a pesquisa. E se reconhecer como um agente de transformação. (E9) 
Com efeito, se entendemos que, no ensino superior, a ênfase deva ser dada às ações do aluno para que ele possa aprender o que se propõe, e que a aprendizagem desejada engloba, além dos conhecimentos necessários, habilidades e análise e desenvolvimento de valores, não há como promover as aprendizagens sem a participação e a parceria dos próprios estudantes.

Incentivar essa participação resulta em uma motivação e no interesse do aluno pela matéria de ensino, e dinamização nas relações entre alunos e professores, facilitando a comunicação entre ambos. O aluno começa a ver no professor um aliado para sua formação, e não um obstáculo, e sente-se igualmente responsável por aprender. Ele passa a se considerar como sujeito do processo de aprender.

Trabalhar com pesquisa, projetos e novas tecnologias, como comentado, se constituiu como caminhos interessantes que, ao mesmo tempo em que incentivavam a pesquisa, facilitavam o desenvolvimento da parceria entre professores e estudantes.

Nos Projetos Pedagógicos dos cursos, percebi que havia preocupação com a busca da articulação das disciplinas com vistas à interdisciplinaridade. No entanto, assim como em grande parte das universidades brasileiras, ainda há dificuldades de superação do modelo tecnicista de formação de professores, em alguns ambientes institucionais. No caso em estudo, percebi que no currículo de Biologia predomina ainda a estruturação de formação que dicotomiza as áreas específicas e pedagógicas, além da introdução tardia dos estudantes no lócus de exercício profissional, que se dá somente nos semestres finais do curso. 


\section{APRENDIZAGENS CONSTRUÍDAS: TECENDO ALGUMAS CONCLUSÕES}

Com o olhar direcionado para a compreensão de como os docentes investigados produzem e interpretam as suas práticas pedagógicas e como são estabelecidas as relações na aula universitária, procurei compreender como esses professores produziram e interpretaram suas práticas nas ações cotidianas da aula. Isso possibilitou encontrar alguns aspectos que parecem pertinentes para a compreensão da docência universitária.

Nesse sentido, foi possível retomar as questões que orientaram esta pesquisa, cujo objetivo foi compreender os modos de produzir e interpretar a prática docente e entender o que leva cada professor a agir de uma determinada forma e não de outra, bem como a relação entre o seu discurso e sua prática em sala de aula. Quis, ainda, entender como os processos de ensino e aprendizagem que o professor protagoniza repercutem na profissionalidade dos alunos, em especial nos cursos de licenciatura, foco desta pesquisa.

O problema de pesquisa definido - Como a trajetória e as práticas de docentes de didática se constituem e repercutem na formação de alunos dos cursos de licenciatura? - envolveu uma complexidade que supôs, ao menos, três dimensões orientadoras para o estudo, que provocaram as questões investigativas, explicitadas no capítulo do desenho metodológico. Retomo as dimensões que orientaram o estudo: $1^{\text {a }}$ Dimensão: Trajetória dos docentes; $2^{\mathrm{a}}$ Dimensão: Práticas dos docentes; $3^{a}$ Dimensão: Repercussões de práticas: a voz dos estudantes.

Essas questões implicaram a construção do desenho metodológico e o tipo de pesquisa realizada. A pesquisa desenvolveu-se contemplando seis docentes universitários dos cursos de Biologia e Pedagogia, que trabalham as disciplinas consideradas pedagógicas, ou seja de Didática-OTP e Didáticas Específicas nos respectivos cursos.

$\mathrm{Na}$ análise dos dados, busquei compreender a prática pedagógica desses docentes considerando as suas particularidades e o contexto econômico e social no qual estão inseridos. Sendo assim, a investigação buscou refletir sobre a docência universitária como um fenômeno complexo.

Busquei valorizar o trabalho que cada docente desenvolvia na sua singularidade, na aproximação com outros docentes e discentes e as contradições existentes no seu fazer pedagógico. Nesse sentido, os diferentes instrumentos de 
coleta de dados me possibilitaram, além de analisar a conexão entre o processo de ensino e de aprendizagem que ocorre na dinâmica da aula, captar as ações e as interações entre docentes e estudantes nas suas manifestações, em seus gestos e silêncios.

Para articular o que os docentes diziam e o que faziam, procurei tornar mais articulada a relação entre a teoria e a prática, o discurso e a ação, a partir dos questionamentos relacionados sobre como eles desenvolviam suas aulas e como os estudantes viam a prática desse docente.

Confirmei que a docência universitária é constituída por um processo complexo, envolvendo a formação do professor, as condições de trabalho, as questões metodológicas, o uso de recursos tecnológicos e didáticos, bem como as condições objetivas do trabalho dos docentes. No caso, a instituição investigada passa por uma crise financeira desde ano de 2009, com atrasos salariais e diminuição de carga horária, culminando, em 2010, com a troca de Reitoria e próreitorias. Contudo, apesar desses agravantes, foi perceptível tanto pelas observações quanto pelas entrevistas que os docentes procuravam desenvolver as suas atividades de forma ética, comprometida e responsável. Quando perguntados sobre essa questão, foram unânimes em responder que a situação é muito difícil, mas que procuram não manifestar essas dificuldades em sala de aula. Isso não significava que eles ignoravam a questão, mas que, a despeito das condições desfavoráveis, as suas aulas se constituíam numa forma de manter a qualidade da universidade. Mesmo assim, ressalta-se que as condições objetivas de trabalho podem interferir na qualidade do ensino.

Reforço que o objeto de estudo esteve centrado nos docentes e em suas práticas, e a repercussão dessa prática na formação dos estudantes dos cursos de licenciatura em Pedagogia e Biologia, mas sempre com o olhar nas práticas singulares de quem as praticava. Não estive focada no como se faz, nas metodologias utilizadas pelos docentes, mas sim nos traços dos sujeitos, suas trajetórias, seu modo de viver e pensar a docência.

Todos os docentes evidenciaram uma relação de gosto e prazer em exercer sua profissão. Manifestaram profissionalismo, dedicação, comprometimento e investimento no desenvolvimento profissional. Também foi possível perceber a capacidade de autonomia para tomada de decisões, tanto referente à sua prática quanto em relação aos objetivos de ensino, materiais utilizados, escolha de 
conteúdo, recursos metodológicos. Todos indicaram possuir uma visão processual do ensino que fazem e sobre a aprendizagem que é desencadeada. Em alguns momentos, observei contradições nesse processo, porém acredito que são sejam ações naturalizadas, como indica Bourdieu (2002).

As experiências, os saberes, os conhecimentos que o professor incorporou e construiu ao longo de sua trajetória, traduzidos em processos formativos, constituem-se num habitus, ou seja, em uma forma de o professor ser, pensar e agir no mundo e na sua prática profissional. Nessa perspectiva, o conceito de formação identifica-se com a ideia de percurso, processo, trajetória de vida pessoal e profissional. Por isso, a formação não se conclui, ela é um processo permanente.

Durante todo o período das observações, busquei verificar como os docentes desenvolviam a sua prática, para que pudesse encontrar indícios de situações de práticas inovadoras. Entendo a inovação como um movimento de ruptura com o pensamento técnico-instrumental, procurando aliar outras racionalidades no processo de ensino e aprendizagem. Identifiquei muitas possibilidades inovativas nas práticas dos docentes, com especial destaque à relação teoria-prática e ao protagonismo docente.

Nas entrevistas, cinco dos docentes destacaram atividades diferenciadas que marcaram as suas trajetórias, e que nessas experiências eles foram os protagonistas.

Ao realizarem suas práticas, os professores afirmam a importância de partilhar decisões com seus alunos. Foi verificado tanto nas entrevistas quanto nas observações das aulas que os docentes estabelecem com os estudantes uma espécie de contrato pedagógico. Há indicativos, também, de que os estudantes, no primeiro contato, reagem a esse contrato com certo estranhamento. Após algumas atividades, consideram interessantes e as desenvolvem com entusiasmo e dedicação. Ao encontro da contribuição de Souza Santos (2000), o novo gera incertezas, desacomoda, obriga a tomada de decisão. Propiciar que os estudantes assumam posições e colocá-los em situação de protagonismo parece ser importante. Ficou manifesto nas entrevistas tanto dos estudantes quanto dos docentes que, após vivenciarem as primeiras atividades, começam a se sentir mais seguros, mais à vontade. Manifestaram alegria e satisfação em aprender e entusiasmo com as experiências vividas. 
Para Cunha (2001), a relação positiva entre docentes e estudantes confirma a condição de que o conhecimento vem sempre no contexto das relações humanas. Sua condição de inteligibilidade e significação está atrelada à forma com que o professor e seus alunos atribuem sentidos às suas práticas. $\mathrm{O}$ entusiasmo, o afeto e a paixão aparecem nas entrevistas dos docentes pesquisados como qualidades que identificavam em seus professores.

Também foi sinalizado pelos docentes que, para produzir rupturas nos processos de ensinar e aprender, foi necessário criar uma cultura de trabalho coletivo com os seus alunos, para que eles trabalhem com o novo, com as incertezas, com os desafios.

Para os professores, a relação entre teoria e prática constitui-se numa referência do trabalho pedagógico que se propõe a fazer rupturas paradigmáticas. Foi possível observar que, nas práticas relatadas, aparecem diversos tipos de atividades, entre elas os trabalhos de campo, a utilização da tecnologia, os projetos de ensino, o trabalho em equipes e as reflexões individuais para sistematização dos estudos.

$\mathrm{Na}$ análise dos relatos dos docentes, percebi que há ações que propiciam a autoria e o protagonismo dos alunos numa perspectiva emancipatória. Também é possível afirmar que, em todas as aulas, pelo menos dois desses indicadores de inovação estavam presentes. Foi também verificado que esses docentes valorizavam as iniciativas de ruptura paradigmática nos processos de ensinar e aprender e tinham a clareza de que esse processo deveria formar futuros professores comprometidos, cidadãos críticos e com condições de continuar a aprender e a produzir conhecimentos socialmente relevantes.

Foi possível também verificar que os docentes lembravam com frequência e de maneira bastante latente situações em que os seus professores desenvolviam atividades consideradas diferenciadas por eles, nas quais eram colocados de maneira significativa como atuantes nas experiências, ou seja, eram estimulados a participar efetivamente de situações no processo de ensino e aprendizagem e no protagonismo dos estudantes. Essas dimensões são apontadas como essenciais por Cunha (1998). Meus interlocutores docentes aprenderam com seus ex-professores e agora se constituem como referentes para seus estudantes. É o processo cultural de formação em movimento. 
De alguma forma, repetem essa cultura com seus alunos. Vivem com eles a didática que querem prescrever, assumindo, na formação de professores, as formas de ensinar que se constituem em conteúdo de aprendizagem. Ou seja, o professor, em especial o professor de Didática, ensina pelo exemplo, pelo que faz junto com seus alunos, pelas metodologias que utiliza, pelas estratégias de relação que põe em prática e pelos modelos de avaliação que instaura. Sua docência é a didática em ação e deve ser explorada tanto nos seus saberes práticos como nos seus pressupostos teóricos.

Nas observações que fiz, percebi que muitos professores têm essa preocupação, da coerência entre o dizer e o fazer. Registrei, de forma intencional em alguns momentos, a exploração teórica dos fazeres que poderiam potencializar o processo de formação dos estudantes, articulando a forma e o conteúdo da Didática com bases teóricas mais consistentes. Mesmo assim, a coerência na ação foi notada pelos estudantes e marca positivamente a sua formação.

Percebi em algumas ações desses docentes o objetivo de potencializar ao aluno aprendiz a compreensão, que a educação, por ser uma experiência especificamente humana, é uma forma de intervenção no mundo,(FREIRE,1998) foi nesse sentido de desenvolver no futuro profissional a autonomia, que muitas atividades em sala de aula ocorriam.

Chego ao final desta pesquisa com a consciência do muito que ainda existe para ser abordado e aprofundado sobre o tema. Os aprendizados foram muitos e foram construídos nos encontros, nas reflexões, nas idas e vindas que toda investigação exige, mas, principalmente, na experiência da escuta. Aprendi muito com as experiências compartilhadas, narradas e vividas pelos docentes e estudantes.

A pesquisa me proporcionou a vivenciar a aula do outro, os erros, acertos, equívocos e ajustes, assim como as formas de incentivo que utilizavam para mobilizar os estudantes.

Tive a satisfação de conviver com estudantes/professores que refletem a sua formação e desejam qualificá-la por meio de suas práticas. Eles enfrentam vários desafios no seu cotidiano, coerências e contradições, mas buscam se manter fortes e determinados ao longo do percurso formativo, atribuindo significado a cada experiência vivida e compartilhada. 


\section{REFERÊNCIAS}

ALARCÃO, I. Professores reflexivos em uma escola reflexiva. São Paulo: Cortez, 2008.

; TAVARES, José. Supervisão da prática pedagógica: uma perspectiva de desenvolvimento e aprendizagem. Porto: Almedina, 2003.

ALMEIDA, Ana Maria B; LIMA, Maria Socorro Lucena; SILVA, Silvina Pimentel, (Org.). Dialogando com a escola: reflexões do estágio e da ação docente nos cursos de formação de professores. Fortaleza: Edições Demócrito Rocha, 2004.

ALMEIDA, Cleide Rita Silvério de. O brasão e o logotipo: um estudo das novas universidades na cidade de São Paulo. Petrópolis: Vozes, 2001.

ANASTASIOU, Lea das G. C. Ensinar, aprender, apreender e processos de ensinagem. In: ANASTASIOU, Lea das G. C.; ALVES, Leonir P. (Org.). Processos de ensinagem na universidade: pressupostos para as estratégias de trabalho em aula. Joinville: Univile, 2005. p. 11-35.

ANASTASIOU, Lea das Graças. Metodologia do Ensino Superior. Curitiba, Editora IBPEX, 1998.

ANDRÉ, Marli. Tendências da pesquisa e do conhecimento didático no início dos anos 2000. In: ENCONTRO NACIONAL DE DIDÁTICA E PRÁTICAS DE ENSINO, 14., 2008, Porto Alegre. Anais... Porto Alegre: PUCRS, 2008.

ARAÚJO, José Carlos $S$. Do quadro-negro à lousa virtual: técnica, tecnologia e tecnicismo. In: VEIGA, Ilma P. A. (Org.). Técnicas de ensino: novos tempos, novas configurações. Campinas: Papirus, 2006. p. 13-48.

BALZAN, Newton César. A Didática e a questão da qualidade do ensino superior. Cadernos CEDES (22). São Paulo: Cortez, 1988.

BATISTA,Sylvia Helena Souza da Silva e BATISTA, Nildo Alves. A Formação do professor universitário:desafios e possibilidades. In: SEVERINO, Joaquim e Fazenda, Ivani (orgs.). Formação Docente: Rupturas e Possibilidades. Campinas, SP: Papirus,2002.

BARDIN, Laurence. Análise de conteúdo. Lisboa: Edições 70, 1977.

BEHRENS, Marilda Aparecida. A formação pedagógica e os desafios do mundo moderno. In: MASETTO, Marcos (Org.). Docência na universidade. Campinas: Papirus, 2002. p. 57-68.

BERBEL, Neusi A. N. Metodologia do ensino superior: realidade e significados. Campinas: Papirus, 1994.

BOLZAN, Doris Pires Vargas. Professores/as como investigadores/as da sua própria prática. Cadernos da Aplicação, Porto Alegre, v. 11, n. 2, jun./dez. 1998. 
Formação de professores: compartilhando e reconstruindo conhecimentos. Porto Alegre: Mediação, 2002.

BOURDIEU, Pierre. Questões de sociologia. Rio de Janeiro: Marco Zero, 1983.

A economia das trocas simbólicas. São Paulo: Perspectiva, 1987.

. Poder simbólico. Lisboa: Bertrand, 1989.

Ática.1983.

O campo científico. In: ORTIZ, Renato. Pierre Bourdieu. São Paulo:

BRASIL. Ministério da Educação. Lei de Diretrizes e Bases da Educação Nacional nº 9.394, de 20 de dezembro de 1996. Brasília: MEC, 1996.

. Ministério da Educação. Resolução CNE/CEB 9, de 8 de maio de 2001.

Diário Oficial da União, Brasília, Seção 1, p. 31, maio 2001.

. Ministério da Educação. Resolução CNE/CEB 01, de 18 de fevereiro de 2002. Diário Oficial da União, Brasília, Seção 1, p. 31, abr. 2002.

. Lei.$^{\circ}$ 9.394, de 20/12/1996. Estabelece a Lei de Diretrizes e Bases da Educação Nacional. Brasília, Distrito Federal. Disponível em:

<http://www.planalto.gov.br/ccivil_03/leis/L9394.html>. Acesso em: 10 de abr. 2009.

. Resolução CNE/CP n 1/02 - Diretrizes Curriculares Nacionais para a Formação de Professores. Brasília, Distrito Federal. Disponível em:

$<$ http://portal.mec.gov.br/seesp/arquivos/pdf/res1 2.pdf> Acesso em: 14 de mai. 2009.

Resolução CNE/CP n 2/02 - Diretrizes Curriculares Nacionais para a Formação de Professores. Brasília, Distrito Federal. Disponível em:

$<$ http://portal.mec.gov.br/seesp/arquivos/pdf/res2 2.pdf> Acesso em: 14 de mai. 2009.

. Educação Superior Brasileira: 1991-2004. Brasília: Instituto Nacional de Estudos e Pesquisas Educacionais Anísio Teixeira, 2006.

. Censo da Educação Superior 2010. Brasília: Instituto Nacional de Estudos e Pesquisas Educacionais Anísio Teixeira, 2011.

CANDAU, Vera Maria (Org.). Ensinar e aprender: sujeitos, saberes e pesquisa. Rio de Janeiro: DP\&A, 2000.

. (Org.) Rumo a uma nova didática.Petrópolis: Vozes, 1988.

CANEN, Ana. Formação de professores e diversidade cultural. In: CANDAU, Vera Maria (Org.). Reinventar a escola. Petrópolis: Vozes, 2000. p.12-22

CASTANHO, Sérgio; VEIGA, IIma Passos Alencastro (Org.) Pedagogia universitária: a aula em foco. Campinas: Papirus, 2001. 
; CASTANHO, Maria Eugênia (Org.). Temas e textos em metodologia do Ensino Superior. Campinas: Papirus, 2004.

CHARLOT, B. A pesquisa educacional entre conhecimentos, políticas e práticas : especificidades e desafios de uma área de saber. Revista Brasileira de Educação, Rio de Janeiro, 2006. P.07-18

CHIZZOTTI, Antônio. Metodologia do ensino superior: o ensino com pesquisa. In: CASTANHO, Sérgio; CASTANHO, Maria Eugênia (Org.). Temas e textos em metodologia do Ensino Superior. Campinas: Papirus, 2004. p. 103-112.

CONTRERAS DOMINGO, José y PÉREZ DE LA FERRÉ, Nuria. La experiência y La investigación educativa. In: CONTRERAS DOMINGO, José y PÉREZ DE LA FERRÉ, Nuria (Comps). Investigar La experiência educativa. Madrid: Morata, 2010.

CORREIA, José Alberto; MATOS, Manuel. Do poder à autoridade dos professores: o impacto da globalização na desconstrução da profissionalidade docente. In: VEIGA, IIma P. A. e CUNHA, Maria Isabel da (Orgs.). Desmistificando a profissionalização do magistério. Campinas: SP, 1999.

CUNHA, Luiz Antônio. A universidade crítica - o ensino superior na República Populista.Rio de Janeiro: Francisco Alves, 1982.

CUNHA, M.I. e FOSTER, Mary Margarete dos Santos. Trilhas investigativas que localizam a inovação na prática pedagógica da universidade: analisando experiências no curso de Direito.In: FRANCO, Maria Estela Dal Pai e KRAHE, Elizabeth D. Pedagogia Universitária e Áreas de Conhecimento.Porto Alegre, EDIPUCRS,2007 a.

. O bom professor e sua prática. Campinas: Papirus, 1989.

1998.

O professor universitário na transição de paradigma. Araraquara: JM,

. Inovação como perspectiva emancipatória no ensino superior: mito ou possibilidade? In: CANDAU, Vera Maria (Org.). Ensinar e aprender: sujeitos, saberes e pesquisa. Rio de Janeiro: DP\&A, 2000.(p. 01-20)

- A geografia social da formação de professores: uma releitura da contribuição de Andy Hargreaves. In: REUNIÃO ANUAL DA ANPED, 24. 2001, Caxambu. Anais... Rio de Janeiro: Anped, 2001. 1 CD-ROM.

$2007 b$.

Reflexões e práticas em pedagogia universitária. Campinas: Papirus,

. O Professor Universitário na transição de paradigmas. $2^{\mathrm{a}}$ Ed. Araraquara: Junqueira \& Marin editores, 2005.

A docência como ação complexa: o papel da didática na formação de professores. In: XII ENDIPE.2004, Curitiba. 
DURAN, E.R. Uma política para o Ensino Superior Brasileiro: diagnóstico e proposta. São Paulo: NUPES, Documento de Trabalho 1, 1998.

FERNANDES, Florestan. Educação e sociedade no Brasil, São Paulo: Dominus/USP, 1966.

FRANCO, Maria Estela Dal Pai e KRAHE, Elizabeth D. Pedagogia Universitária e Áreas de Conhecimento.Porto Alegre, EDIPUCRS,2007.

FREIRE, Paulo. Pedagogia da autonomia: saberes necessários à prática educativa. São Paulo: Paz e Terra, 1996.

. Pedagogia da indignação. São Paulo: UNESP, 2000.

. Pedagogia do Oprimido. São Paulo: Paz e Terra, 1970.

Freire P. e Shor, Ira. Medo e ousadia: o cotidiano do professor. Rio de Janeiro: Paz e Terra, 2000.

GARCIA, Carlos M. Formação de professores: para uma mudança educativa. Porto: Porto, 1999.

GATTI, Bernardete Angelina. Grupo focal na pesquisa em ciências sociais e humanas. Brasília: Líber Livro, 2005.

A pesquisa e a didática. In: ENCONTRO NACIONAL DE DIDÁTICA E PRÁTICAS DE ENSINO, 14., 2008, Porto Alegre. Anais... Porto Alegre: PUCRS, 2008.

GIL, Antonio Carlos. Como elaborar projetos de pesquisa. São Paulo: Atlas, 2006.

GUSDORF, Georges. Professores para quê? Para uma pedagogia da pedagogia.Tradução M.F.,3 ed. São Paulo: Martins Fontes, 2003.

GOFFMAN, E. A representação do Eu na vida cotidiana. Petrópolis, RJ: Vozes, 2003.

HABERMAS, JÜRGEN. Aclaraciones a La Ética Del Discurso, 2000: Colección de Clásicos Del Pensamiento Universal ' carrasc - - Livro digital Cod: 2975942 (9781413544350 - 2975942). Acesso Nov.2013.

IMBERNÓN, Francisco. La formación del profesorado.Barcelona: Paidós,1994

INSTITUTO BRASILEIRO DE GEOGRAFIA E ESTATÍSTICA. Censo 2010. Brasília: IBGE, 2010. Disponível em: <http://censo2010.ibge.gov.br>. Acesso em: 12 dez. 2013.

ISAIA, Silvia Maria de Aguiar. O professor universitário no contexto de sua trajetória como pessoa e profissional. In: MOROSINI, Marília Costa (Org.). Professor do ensino superior: identidade, docência e formação. Brasília: Plano, 2001. p. 35-60. 
; BOLZAN, Doris Pires V. Formação do professor do ensino superior: um processo que se aprende? Revista Educação, Santa Maria, v. 29, n. 2, p. 121-133, 2004. Dossiê: formação de professores e profissionalização docente.

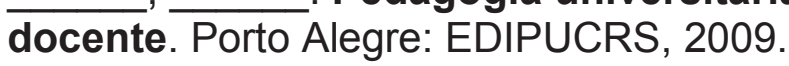

. Pedagogia universitária e desenvolvimento profissional

KRAHE, E. D. Licenciaturas e suas modificações curriculares: as determinações legais do MEC-BR e os currículos da UFRGS. Educação, Santa Maria. V29.n.2,p146-158,2004.

LARROSA, J. El trabajo epistemológico em Pedagogia. Barcelona: PUF,1990

LEITE, D.(org.) Pedagogia Universitária. Conhecimento, ética, poder e política no ensino superior. Porto Alegre: EDUFRG,1999.

LEITE, Denise, MOROSINI, Marilia (orgs.) Universidade Futurante. Campinas, Papirus, 1997.

- Conhecimento social na sala de aula universitária e a autoformação docente. In: MOROSINI, Marilia C. (Org.). Professor do Ensino Superior: Identidade, docência e formação. Brasilia: Plano editora, 2001. p. 93-108.

LIBÂNEO, José Carlos. A integração entre a Didática e a Epistemologia das disciplinas: uma via para a renovação dos conteúdos da Didática. In: DAUBEN, Angela; DINIS, Julio; SANTOS, Lucilia (Org.) Convergências e tensões no campo da formação e do trabalho docente: didática, formação de professores, trabalho docente. Belo Horizonte: Autêntica, 2010.

- Panorama do ensino da Didática das metodologias específicas e das disciplinas conexas nos cursos de Pedagogia: repercussões na qualidade e na formação profissional. In: LONGAREZI, Andreia; POENTES, Roberto (Org.). Panorama da didática: ensino, prática e pesquisa. Campinas: Papirus, 2011. p. 1150.

Produção de saberes na escola: suspeitas e apostas. 2002. Disponível em: http:/www.educacaoonline.pro.br/art_producao_de_saberes.asp.>. Acesso: 26 maio 2009.

LOURO, Guacira Lopes. Gênero, sexualidade e educação: uma perspectiva pósestruturalista. Petrópolis: Vozes, 1997.

LUCARELLI, Elisa. Enseñar y aprender en la universidad: la articulación teoríapráctica como eje de la innovación en el aula universitaria. In: CANDAU, Vera Maria (Org.). Ensinar e aprender: sujeitos, saberes e pesquisa. Rio de Janeiro: DP\&A, 2000.

. Una investigación en proceso: la formación de aprendizajes complejos en la universidad. Buenos Aires: Programa Estudios sobre el aula universitaria. Instituto de investigaciones en Ciencias de la Educación. Universidad de Buenos Aires [19--]. In: CONGRESSO INTERNACIONAL DE EDUCAÇÃO, 2005, São Leopoldo. Anais. São Leopoldo: Unisinos, 2005. 1 CD-ROM. 
LÜDKE, Menga, ANDRÉ, Marli. Pesquisa em Educação: Abordagens Qualitativas. São Paulo: E.P.U., 1986.

MARCELO GARCÍA, Carlos. A formação de professores: novas perspectivas baseadas na investigação sobre o pensamento do professor. In: NÓVOA, António de Sampaio da. (Org.). Os professores e a sua formação. Lisboa: Dom Quixote, 1997. p. $51-76$.

Editora, 1999.

Formação de professores: para uma mudança educativa. Portugal: Porto

MARCONI, M.; LAKATOS, E. Técnicas de pesquisa: planejamento e execução de pesquisas, amostragens e técnicas de pesquisa, elaboração e análise e interpretação de dados. 5. ed. São Paulo: Atlas, 2002.

MARQUES, Mario Osorio. Escrever é preciso: o princípio da pesquisa. ljuí: Unijuí, 2001.

MARTINS, Carlos Benedito. Ensino pago: um retrato sem retoques. São Paulo: Cortez, 1988.

. O novo ensino superior privado no Brasil (1964-1980). Revista Estudos Pedagógicos, Brasília, v. 70, n. 165, 1989.

MARTINS, Pura Lucia Oliver. As formas e práticas de interação entre professores e alunos. In: VEIGA, IIma P. A. (Org.). Lições de didática. Campinas: Papirus, 2006. p. $75-100$.

MASETTO, M. Docência na universidade. Campinas: Papirus, 1998.

.Docência universitária: repensando a aula. In:Teodoro, A, Vasconcelos, M. L. (orgs). Ensinar e aprender no ensino superior: por uma epistemologia da curiosidade na formação universitária. São Paulo: Mackenzie, 2003. p.79-108

Summus, 2003.

Competência Pedagógica do Professor Universitário. São Paulo:

MINAYO, Maria Cecília de Souza. O Desafio do Conhecimento: pesquisa qualitativa em saúde. 2.ed. São Paulo: Hucitec/ Abrasco, 1993.

.Pesquisa Social: teoria, método e criatividade. Petrópolis, [s. ed.], 1994.

O desafio do conhecimento: pesquisa qualitativa em saúde. Rio de Janeiro: Hucitec,1998.

O desafio do conhecimento: pesquisa qualitativa em saúde. São Paulo: HUCITEC e Rio de Janeiro: ABRASCO,2000.

MIZUKAMI, Maria da Graça N.et al. Escola e aprendizagem da docência:

Processos de investigação e formação.São Carlos: Ed. Da UFSCar,2002.

Ensino: as abordagens do processo. São Paulo: EPU, 1986. 
MORIN, Edgar. Os sete saberes necessários à educação do futuro. São Paulo: Cortez, 2000.

. Introdução ao pensamento complexo. Lisboa: Instituto Piaget, 2003.

MOROSINI, Marília (Org.). Enciclopédia de pedagogia universitária. v. 1. Porto Alegre: RIES/Fapergs, 2003.

. Educação Superior no Brasil - características e tendências no novo milênio. In: CASTRO, Marta Luz Sisson de; WERLE, Flávia Obino Corrêa. Educação comparada na perspectiva da globalização e da autonomia. São Leopoldo: Editora da Unisinos, 2000. p. 137-154.

. Professor do Ensino Superior: Identidade, docência e formação. Brasilia: Plano editora, 2001.

NOGUEIRA, Maria Alice e CATANI, Afrânio(Orgs.). Escritos de Educação. Pierre Bourdieu.Rio de Janeiro: Vozes, 2002

NÓVOA, António de Sampaio da. Os professores e sua formação. Lisboa: Dom Quixote, 1992.

. Os professores e a sua formação. Lisboa: Publicações Dom Quixote; Instituto de Inovação Educacional, 1995. Educação).

Profissão professor. Porto: Porto Editora, 1995. (Coleção Ciências da

. O Regresso dos professores. Mimeo. 2011.

. Os professores e as histórias da sua vida. In: NÓVOA, Antonio (Org.).

Vidas de professores. Porto Editora, Porto, Portugal, 2007.

OLIVEIRA, Valeska Maria Fortes de. O imaginário social e a escola de ensino médio. Ijuí: Unijuí, 1997.

et al. O oral e a fotografia na pesquisa com professores. In: SEMINÁRIO INTERNACIONAL, 2., 2003, Rio de Janeiro. As redes de conhecimento e a tecnologia: imagem e cidadania. UERJ, 2003.

OLIVEN, Arabela Campos. Universidade brasileira "indústria do conhecimento" ou consciência das comunidades. Educação Brasileira, Brasília, v. 9, n. 19, 1987.

PACHANE, Graziela Giusti. Teoria e prática na formação de professores universitários: elementos para discussão. Publicatio UEPG, Ponta Grossa, v. 14, n. 1, p. 13-24, 2005.

PERRENOUD, Philippe. Formar professores em contextos sociais em mudança: prática reflexiva e participação crítica. Revista Brasileira de Educação, São Paulo, n. 12, set./dez. 1999. 
PIMENTA, Selma Garrido. A prática (e a teoria) docente ressignificando a didática. In: OLIVEIRA, Maria Rita N. S. (Org.). Confluências e divergências entre didática e currículo. São Paulo: Papirus, 1998.

. Anastasiou,Léa C. Docência no ensino superior. São Paulo: Cortez. (Coleção Docência em Formação 1),2002.

.(Org.) Saberes Pedagógicos e atividade docente. São Paulo: Cortez, 2005.

. O estágio na formação de professores: unidade teoria e prática?7 ed.

São Paulo: Cortez, 2006.

PIMENTEL, Maria da Glória. O Professor em Construção. São Paulo: Papirus,1993.

PONS, Juan de P. El trabajo en el aula: elementos didácticos e organizativos.

Sevilla: Ediciones Alfar, 1988.

POPKEWITZ, Thomas S. Reforma educacional: Uma política sociológica. Poder e conhecimento em Educação. Porto Alegre: Artes Médicas,1997.

RIBEIRO, Darcy. A universidade necessária. Rio de Janeiro: Paz e Terra, 1969.

ROMANELLI, Otaíza Oliveira. História da Educação no Brasil (1930-1973).

Petrópolis: Vozes, 1985.

SACRISTÁN, Gimeno J. e GOMES, A. L. Pérez. Compreender e transformar o ensino. Porto Alegre: Artes Médicas, 1998.

SACRISTÁN, Gimeno J. Consciência e acção sobre a prática como libertação profissional dos professores. In: NÓVOA, António de Sampaio da (Org.). Profissão professor. Porto: Porto Editora 1995. p. 63-92.

SANTOS, Lucíola L. C. Pluralidade de saberes em processos educativos. In: CANDAU, Vera Maria (Org.). Didática, currículo e saberes escolares. Rio de Janeiro: DP\&A, 2000. p. 46-59.

SHÖN, D. A. Formar professores como profissionais reflexivos. In: NÓVOA, António de Sampaio da (Org.). Profissão professor. Porto: Porto Editora 1995. p. 95-114.

. La formación de profesionales reflexiveis: hacia um nuevo diseño de la enseñanza y el aprendizaje en las profesiones. Madrid,Paidós, 1992

SOBRAL, Fernanda da Fonseca. Educação, Universidade e Sociedade. In:CADERNOS DE SOCIOLOGIA/PROGRAMA PÓS-GRADUAÇÃO EM SOCIOLOGIA. V.4, número especial. Porto Alegre: PPGS/UFRGS,1993.

SOUSA SANTOS, Boaventura de. Introdução a uma ciência pós-moderna. Rio de Janeiro: Graal, 1989.

Pela mão de Alice: o social e o político na pós-modernidade. São Paulo: 
Para um novo senso-comum: a ciência, o direito e a política na transição paradigmática. São Paulo: Cortez, 2000.

A crítica da razão indolente: contra o desperdício da experiência. São Paulo: Cortez, 2002.

A universidade no século XXI: para uma reforma democrática e emancipatória da universidade. São Paulo: Cortez, 2004.

TARDIF, Maurice. Saberes docentes e formação profissional. Petrópolis: Vozes, 2002.

; LESSARD, Claude. O trabalho docente: elementos para uma teoria da docência como profissão de interações humanas. Petrópolis: Vozes, 2005.

; RAYMOND, D. Saberes, tempo e aprendizagem no magistério. Educação e Sociedade.v.21,n.73, p.209-244,dez.2000.

TRINDADE, Liana; LAPLANTINE, François. O que é imaginário. São Paulo: Brasiliense, 1997. (Coleção Primeiros Passos, 309).

TRIVIÑOS, Augusto. N. S. Introdução à pesquisa em Ciências Sociais: a pesquisa qualitativa em educação. São Paulo: Atlas, 1987.

VÁZQUEZ, Adolfo S. Filosofia da práxis. Rio de Janeiro: Paz e Terra, 1977.

VEIGA, IIma P. A. O projeto e a parametrização do MEC. In: Educação

básica e educação superior: projeto político-pedagógico. Campinas: Papirus, 2004. p. 47-74.

. Lições de Pedra: a sala de aula e a produção do aluno. In: VIELLA, M. dos A.

(Org.). Tempos e espaços de formação. Chapecó: Argos, 2003.

. Ensinar: uma atividade complexa e laboriosa. In: VEIGA, IIma P.A., (org.).

Lições de didática. Campinas: Papirus, 2006.

. Pedagogia universitária: A aula em foco. Campinas: Papirus,2000.

VIÑAO FRAGO, A. e ESCOLANO, A. Currículo, espaço e subjetividade: A arquitetura como programa. Rio de Janeiro: DP\&A, 2001.

VEIGA-NETO, Alfredo. Equívocos ou o (falso) problema da relação entre teoria e prática, na formação docente. 2003. (Resumo de texto publicamente apresentado e discutido na Ulbra, Canoas-RS).

ZABALA, A. A prática educativa: como ensinar. (Ernani da F. Rosa, Trad.) Porto Alegre: Artmed.1998.

ZABALZA, Miguel A. O ensino universitário: seu cenário e seus protagonistas. Porto Alegre: Artmed, 2004. 


\section{APÊNDICE A - Termo de Consentimento Livre e Esclarecido}

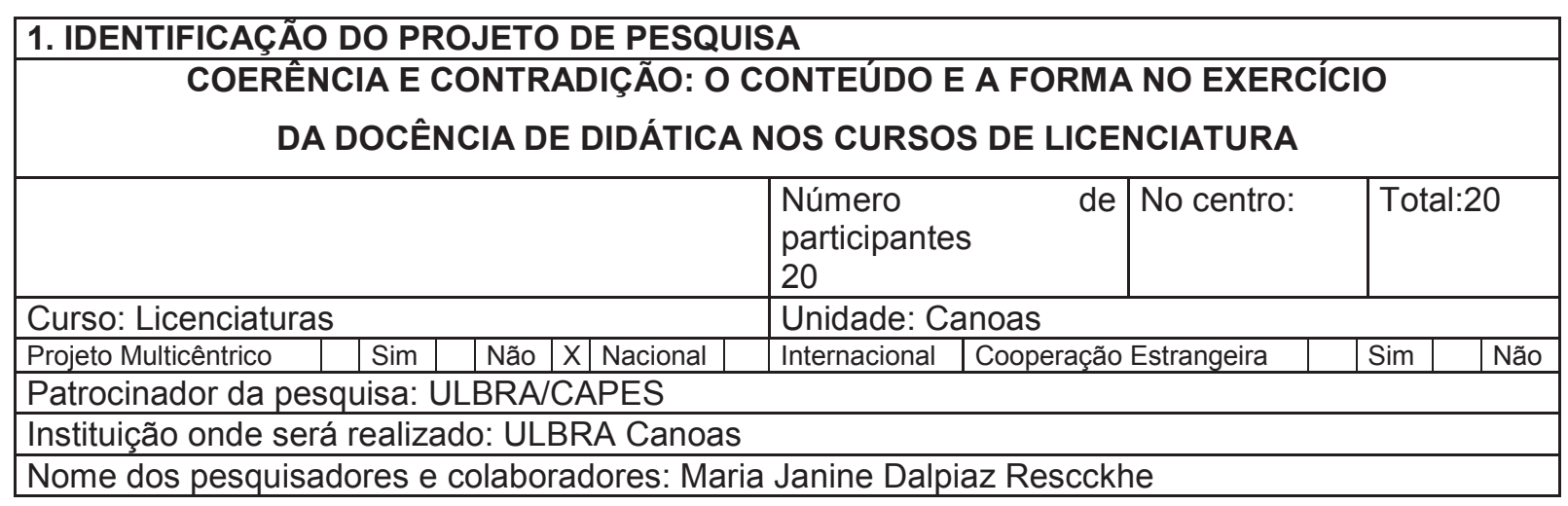

Você está sendo convidado(a) para participar do projeto de pesquisa acima identificado. O documento abaixo contém todas as informações necessárias sobre a pesquisa que estamos fazendo. Sua colaboração neste estudo será de muita importância para nós, mas se desistir, a qualquer momento, isso não causará nenhum prejuízo para você.

\begin{tabular}{|l|l|l|l|}
\hline \multicolumn{4}{|l|}{ 2. IDENTIFICAÇÃO DO SUJEITO DA PESQUISA } \\
\hline Nome: & Estado Civil: & Profissão: & Sexo: \\
\hline Nacionalidade: & Telefone: & E-mail: \\
\hline RG: & CPF/MF: & & \\
\hline Endereço:
\end{tabular}

\begin{tabular}{|c|c|c|}
\hline \multicolumn{3}{|c|}{ 3. IDENTIFICAÇÃO DO PESQUISADOR RESPONSÁVEL } \\
\hline \multicolumn{2}{|c|}{ Nome: Maria Janine Dalpiaz Reschke } & Telefone:96366934 \\
\hline Profissão: Professora & Registro no Conselho $\mathrm{N}^{\circ}$ : & E-mail:mjanine@terra.com.br \\
\hline
\end{tabular}

Eu, sujeito da pesquisa, abaixo assinado(a), após receber informações e esclarecimento sobre o projeto de pesquisa, acima identificado, concordo de livre e espontânea vontade em participar como voluntário(a) e estou ciente:

\section{Da justificativa e dos objetivos para realização desta pesquisa}

- Os docentes das disciplinas pedagógicas tornam-se referências para seus estudantes e suas práticas pedagógicas ensinam tanto quanto os seus conteúdos.

- Se esta premissa é considerada importante, compreender como os docentes universitários que atuam nos cursos de licenciatura.Como constroem suas práticas docentes também passa a ser fundamental.

\section{Do objetivo de minha participação}

- Investigar suas expectativas em relação a instauração de processos institucionais de 
formação pedagógica para o desenvolvimento da "profissionalidade" docente entre os professores dos respectivos curso de graduação.

- Reunir elementos para orientar a organização de processo de formação pedagógica que contribuam para as mudanças no ensino de graduação que o contexto da universidade particular esta demandando.

\section{Do procedimento para coleta de dados}

Para coletar os dados que se referem à profissionalidade dos docentes universitários e as trajetórias de formação, será realizadasa entrevistas semiestruturadas.

A compreensão das práticas desenvolvidas remete à exigência da observação de situações de ensino-aprendizagem, usando registros sistemáticos.

- Prevê-se o acompanhamento dos docentes pela observação em, ao menos, quatro situações pedagógicas. Estas serão previamente combinadas com os evolvidos.

\section{Da utilização, armazenamento e descarte das amostras}

Os dados serão armazenados pela pesquisadora e ficarão disponíveis para todos os participantes dessa pesquisa. As entrevistas serão utilizadas parcialmente em artigos que serão publicados.

\section{Dos desconfortos e dos riscos}

Não se aplica.

\section{Dos benefícios}

Propiciar momentos de reflexão coletiva sobre a profissionalidade, discussões para uma maior interação pela troca de experiência.

\section{Da isenção e ressarcimento de despesas}

A participação é isenta de qualquer ressarcimento de despesas.

\section{Da liberdade de recusar, desistir ou retirar meu consentimento}

Tenho a liberdade de recusar, desistir ou de interromper a colaboração nesta pesquisa no momento em que desejar, sem necessidade de qualquer explicação

\section{Da garantia de sigilo e de privacidade}

Os resultados obtidos durante este estudo serão mantidos em sigilo, mas concordo que sejam divulgados em publicações científicas, desde que meus dados pessoais não sejam mencionados

\section{Da garantia de esclarecimento e informações a qualquer tempo}

Tenho a garantia de tomar conhecimento e obter informações, a qualquer tempo, dos procedimentos e métodos utilizados neste estudo, bem como dos resultado, parciais e finais, desta pesquisa. Para tanto, poderei consultar o pesquisador responsável (acima identificado) ou o Comitê de Ética em Pesquisa da ULBRA Canoas(RS), com endereço na Rua Farroupilha, 8001 - Prédio 14 - Sala 224, bairro São Luís, telefone (51) 477-9217, e-mail comitedeetica@ulbra.br 
Declaro que obtive todas as informações necessárias e esclarecimento quanto às dúvidas por mim apresentadas e, por estar de acordo, assino o presente documento em duas vias de igual conteúdo e forma, ficando uma em minha posse.

de de

Maria Janine Dalpiaz Reschke

Testemunhas:

Nome:

RG:

CPF/MF:

Telefone:

\section{Nome:}

RG:

CPF/MF:

Telefone: 


\title{
APÊNDICE B - Roteiro de entrevista aos professores das disciplinas de Didática-OTP e Didáticas Específicas
}

\section{APÊNDICE C - Roteiro de entrevista com os docentes}

\author{
Pesquisa: COERÊNCIA E CONTRADIÇÃO: O CONTEÚDO E A FORMA NO EXERCÍCIO DA \\ DOCÊNCIA NOS CURSOS DE LICENCIATURA. \\ Pesquisadora: Maria Janine Dalpiaz Reschke
}

Inicialmente obrigada por disponibilizar um tempo para responder os meus questionamentos. Vocês são muito importantes para os resultados da pesquisa. No anexo 1 esta o Termo de Consentimento livre e esclarecido (TCLE).

Professor:

Disciplina:

Roteiro de Entrevista

1- Conte sobre a sua trajetória docente. Procure lembrar de fatos e professores que marcaram a sua formação. Influências na sua escolha.

2- Onde fizeste a tua formação? Como percebes o teu percurso nessa caminhada e que aprendizagens tiveste que tenham te propiciado a pensar sobre a tua prática?

3- Que teorias fundamentam a tua prática?

4- Como organizas a tua disciplina? Conteúdo e forma (estratégias que utilizas)?

5- Fale um pouco sobre a tua aula, como organizas o tempo e o espaço dela? Como a desenvolve? Gostaria que descrevesses para mim como costumam acontecer as tuas aulas.

6- Como propicias aos teus alunos que estabeleçam relação com o conteúdo que estás trabalhando e a prática na sala de aula? Que recursos utilizas? A pesquisa faz parte do cotidiano da tua sala de aula?

7- Em que medida consideras que a tua prática é permeada pela relação com teus alunos?

8- Como os teus alunos reagem às tuas aulas?

9- O que não perguntei e acreditas que seja relevante para que eu compreenda que tu és como professor hoje. Há alguma coisa que gostarias de comentar, contar? 


\title{
APÊNDICE C - Roteiro de entrevista com os acadêmicos
}

\author{
Pesquisa: COERÊNCIA E CONTRADIÇÃO: O CONTEÚDO E A FORMA NO EXERCÍCIO DA \\ DOCÊNCIA NOS CURSOS DE LICENCIATURA. \\ Pesquisadora: Maria Janine Dalpiaz Reschke
}

Roteiro da Entrevista com os acadêmicos.

Inicialmente obrigada por disponibilizar um tempo para responder os meus questionamentos. Vocês são muito importantes para os resultados da pesquisa. No anexo 2 esta o Termo de Consentimento livre e esclarecido (TCLE).

- Dados de identificação.

- Idade:

- Estado civil: Possui filhos? Quantos?

- Sexo:

- Semestre:

- Disciplina que estava cursando no momento da pesquisa:

- Cidade que reside:

- Você trabalha em escola? Caso negativo informe a área de trabalho.

- Este trabalho esta no mesmo município que você estuda?

1- Indique quais os motivos que o levaram a escolher este curso?

2- O que consideras como uma boa aula?

3- Com relação a esta disciplina fale um pouco sobre as estratégias metodológicas utilizadas pelo (a) professor(a).

4- Das estratégias utilizadas quais considera a(s) mais significativa(s)? Por quê?

5- Utilizas ou utilizaria algumas destas estratégias na sua prática pedagógica? Quais? E por quê?

6- Com relação à prática do professor desta disciplina. Coloque em ordem crescente de importância as aprendizagens que fizeste a partir da vivência com o professor e colegas nesta disciplina. (1 para a maior aprendizagem e 7 para a menor).

\begin{tabular}{|l|l|l|l|l|l|l|}
\hline $\begin{array}{l}\text { Formas } \\
\text { de } \\
\text { avaliação }\end{array}$ & $\begin{array}{l}\text { Organização } \\
\text { da sala de } \\
\text { aula }\end{array}$ & $\begin{array}{l}\text { Ensino e } \\
\text { pesquisa }\end{array}$ & $\begin{array}{l}\text { Concepção } \\
\text { de } \\
\text { conhecimento }\end{array}$ & $\begin{array}{l}\text { Construção } \\
\text { de } \\
\text { recursos } \\
\text { didáticos }\end{array}$ & $\begin{array}{l}\text { Relação } \\
\text { teoria e } \\
\text { prática }\end{array}$ & $\begin{array}{l}\text { Relação } \\
\text { professor } \\
\text { e aluno. }\end{array}$ \\
\hline & & & & & & \\
\hline
\end{tabular}

7- Quais foram as principais dificuldades e avanços durante esta disciplina que vivenciaste?

8- Com relação às aprendizagens significativas nesta disciplina o que poderias contar?

9- Algo a mais que gostaria de comentar?

Obrigada.

Maria Janine Dalpiaz Reschke 


\section{ANEXO A - Matriz curricular do curso de Pedagogia}

O quadro abaixo apresenta a organização curricular do curso.

\begin{tabular}{|c|c|c|c|c|c|}
\hline CÓDIGO & DISCIPLINAS & SEM & $\mathrm{CH}$ & CRED & SEQ \\
\hline 901201 & ATIVIDADES COMPLEMENTARES & 0 & 100 & 0 & 0 \\
\hline 990101 & COMUNICACAO E EXPRESSAO & 1 & 68 & 4 & 1 \\
\hline 901175 & HISTORIA DA EDUCACAO & 1 & 68 & 4 & 2 \\
\hline 901173 & $\begin{array}{l}\text { PSICOLOGIA DO DESENVOLVIMENTO E DA } \\
\text { APRENDIZAGEM }\end{array}$ & 1 & 68 & 4 & 3 \\
\hline 901020 & LUDICIDADE E PSICOMOTRICIDADE & 1 & 68 & 4 & 4 \\
\hline 901178 & ARTE E EDUCACAO & 1 & 68 & 4 & 5 \\
\hline 901182 & DESENVOLVIMENTO DA LINGUAGEM HUMANA & 2 & 68 & 4 & 6 \\
\hline 901122 & LITERATURA INFANTO-JUVENIL & 2 & 68 & 4 & 7 \\
\hline 901495 & $\begin{array}{l}\text { FUNDAMENTOS TEORICOS E METODOLOGICOS DA } \\
\text { EDUCACAO INFANTIL }\end{array}$ & 2 & 68 & 4 & 8 \\
\hline 901203 & ESCOLA E CURRICULO & 2 & 68 & 4 & 9 \\
\hline 104509 & PRODUÇÃO TEXTUAL & 2 & 68 & 4 & 10 \\
\hline 901497 & $\begin{array}{l}\text { FUNDAMENTOS TEORICOS E METODOLOGICOS } \\
\text { DOS ANOS INICIAIS }\end{array}$ & 2 & 68 & 4 & 11 \\
\hline 901007 & $\begin{array}{l}\text { DIDATICA: ORGANIZACAO DO TRABALHO } \\
\text { PEDAGOGICO }\end{array}$ & 3 & 68 & 4 & 12 \\
\hline 901479 & EDUCAÇÃO MUSICAL & 3 & 68 & 4 & 13 \\
\hline 901496 & FUNDAMENTOS DA AÇÃO PEDAGÓGICA & 3 & 68 & 4 & 14 \\
\hline 901480 & ALFABETIZAÇÃO E LETRAMENTO & 3 & 68 & 4 & 15 \\
\hline 901190 & $\begin{array}{l}\text { ORGANIZACAO DOS TEMPOS E ESPACOS NA } \\
\text { INFANCIA }\end{array}$ & 3 & 68 & 4 & 16 \\
\hline 901481 & POLÍTICAS E NORMAS DA EDUCAÇÃO BÁSICA & 3 & 68 & 4 & 17 \\
\hline 101636 & LÍNGUA PORTUGUESA NOS ANOS INICIAIS & 4 & 68 & 4 & 18 \\
\hline 901498 & $\begin{array}{l}\text { FUNDAMENTOS TEORICOS E METODOLOGICOS DA } \\
\text { MATEMATICA }\end{array}$ & 4 & 68 & 4 & 19 \\
\hline 901038 & PROJETOS INTERDISCIPLINARES & 4 & 68 & 4 & 21 \\
\hline 901185 & $\begin{array}{l}\text { FUNDAMENTOS TEORICOS E METODOLOGICOS DAS } \\
\text { CIENCIAS NATURAIS }\end{array}$ & 4 & 68 & 4 & 22 \\
\hline 901499 & ESTAGIO CURRICULAR: EDUCAÇÃO INFANTIL & 4 & 102 & 6 & 23 \\
\hline 901500 & EDUCACAO DE JOVENS E ADULTOS & 5 & 68 & 4 & 24 \\
\hline 990103 & INSTRUMENTALIZACAO CIENTIFICA & 5 & 68 & 4 & 25 \\
\hline 901501 & $\begin{array}{l}\text { PSICOLOGIA DO DESENVOLVIMENTO E } \\
\text { APRENDIZAGEM: ADOLESCÊNCIA E VIDA ADULTA }\end{array}$ & 5 & 68 & 4 & 26 \\
\hline 901184 & $\begin{array}{l}\text { FUNDAMENTOS TEORICOS E METODOLOGICOS DAS } \\
\text { CIENCIAS HUMANAS }\end{array}$ & 5 & 68 & 4 & 27 \\
\hline 901191 & EDUCACAO INCLUSIVA & 5 & 68 & 4 & 28 \\
\hline 901502 & ESTAGIO CURRICULAR: ANOS INICIAIS E/OU EJA-AI & 5 & 102 & 6 & 29 \\
\hline 901174 & FILOSOFIA DA EDUCACAO & 6 & 68 & 4 & 30 \\
\hline 901483 & $\begin{array}{l}\text { METODOLOGIA DO ENSINO DA MATEMÁTICA } \\
\text { APLICADA À EDUCAÇÃO INFANTIL E ANOS INCIAIS }\end{array}$ & 6 & 68 & 4 & 31 \\
\hline 901503 & GESTÃO DA EDUCAÇÃO BÁSICA & 6 & 68 & 4 & 32 \\
\hline 990100 & CULTURA RELIGIOSA & 6 & 68 & 4 & 33 \\
\hline 901198 & PEDAGOGIA E AMBIENTES NAO ESCOLARES & 6 & 68 & 4 & 34 \\
\hline 901505 & $\begin{array}{l}\text { ESTAGIO CURRICULAR: FORMAÇÃO PEDAGÓGICA E } \\
\text { EDUCAÇÃO PROFISSIONAL EM AE OU ANE }\end{array}$ & 6 & 68 & 4 & 35 \\
\hline 901202 & SOCIOLOGIA DA EDUCACAO & 7 & 68 & 4 & 36 \\
\hline 901504 & PROCESSOS INVESTIGATIVOS NA EDUCACAO & 7 & 68 & 4 & 37 \\
\hline 901482 & GESTÃO DE PROCESSOS AVALIATIVOS & 7 & 68 & 4 & 38 \\
\hline 901009 & $\begin{array}{l}\text { TECNOLOGIA DA INFORMACAO E COMUNICACAO } \\
\text { NA EDUCACAO }\end{array}$ & 7 & 68 & 4 & 39 \\
\hline 990102 & SOCIEDADE E CONTEMPORANEIDADE & 7 & 68 & 4 & 40 \\
\hline
\end{tabular}




\begin{tabular}{|c|l|c|c|c|c|}
\hline 101643 & LIBRAS & 7 & 68 & 4 & 40 \\
\hline 901506 & ESTAGIO CURRICULAR: GESTÃO EM AE OU ANE & 7 & 68 & 4 & 41 \\
\hline 901034 & INTRODUCAO A PSICOPEDAGOGIA & 8 & 68 & 4 & 42 \\
\hline 901507 & $\begin{array}{l}\text { DINÂMICAS INTERPESSOAIS: VISÃO } \\
\text { INTERDISCIPLINAR }\end{array}$ & 8 & 68 & 4 & 43 \\
\hline 901199 & ETICA: EDUCACAO E TRABALHO & 8 & 68 & 4 & 44 \\
\hline 901176 & PSICODINAMICA DA APRENDIZAGEM & 8 & 68 & 4 & 45 \\
\hline 901196 & PEDAGOGIA SOCIAL & 8 & 68 & 4 & 46 \\
\hline & Total de horas/aula: & \multicolumn{4}{|c|}{3.296} \\
\hline
\end{tabular}




\section{ANEXO B - Matriz curricular do curso de Biologia}

\begin{tabular}{|c|c|c|c|c|c|c|}
\hline $\begin{array}{l}\text { Unidade: } \\
\text { Curso: }\end{array}$ & $\begin{array}{l}10 \text { CANOAS - GRADUAÇÃO } \\
010654 \text { CIENCIAS BIOLOGICAS - LICENCIATURA }\end{array}$ & Situação: AT & IVO & & & \\
\hline Habilitaçấ & äo: LICENCIADO(A) EM CIENCIAS: BIOLOGIA - LICENCIATURA PLENA & & & & & \\
\hline Com Ren & lovação Reconhecimento: Portaria Nro 286 - D.O.U. DE 27/12/2012 & & & & & \\
\hline Disciplin & & & & & & \\
\hline Código & Nome & Sem & $\mathrm{CH}$ & Cred & Seq Mod & Cat \\
\hline 201692 & ATIVIDADES COMPLEMENTARES & 0 & 225 & 0 & 0 & \\
\hline 201531 & ANATOMIA HUMANA & 1 & 68 & 4 & 1 & \\
\hline 201500 & BIOLOGIA GERAL & 1 & 68 & 4 & 2 & \\
\hline 901174 & FILOSOFIA DA EDUCACAO & 1 & 68 & 4 & 3 & \\
\hline 201502 & ECOLOGIA GERAL & 1 & 68 & 4 & 4 & \\
\hline 201507 & ZOOLOGIA DE INVERTEBRADOS I & 1 & 68 & 4 & 5 & \\
\hline 990103 & INSTRUMENTALIZACAO CIENTIFICA & 1 & 68 & 4 & 6 & \\
\hline 201629 & FUNDAMENTOS DE QUIMICA & 2 & 34 & 2 & 7 & \\
\hline 201651 & FUNDAMENTOS DE FISICA & 2 & 34 & 2 & 8 & \\
\hline 990101 & COMUNICACAO E EXPRESSAO & 2 & 68 & 4 & 9 & \\
\hline 201684 & ANATOMIA VEGETAL & 2 & 68 & 4 & 10 & \\
\hline 201685 & BIOLOGIA CELULAR E TECIDUAL & 2 & 68 & 4 & 11 & \\
\hline 901203 & ESCOLA E CURRICULO & 2 & 68 & 4 & 12 & \\
\hline 201509 & ZOOLOGIA DE INVERTEBRADOS ॥ & 2 & 68 & 4 & 13 & \\
\hline 901173 & PSICOLOGIA DO DESENVOLVIMENTO E DA APRENDIZAGEM & 3 & 68 & 4 & 14 & \\
\hline 901007 & DIDATICA: ORGANIZACAO DO TRABALHO PEDAGOGICO & 3 & 68 & 4 & 15 & \\
\hline 408512 & BIOQUIMICA & 3 & 68 & 4 & 16 & \\
\hline 900506 & OPTATIVA & 3 & 68 & 4 & 17 & \\
\hline 201686 & FISIOLOGIA VEGETAL & 3 & 34 & 2 & 18 & \\
\hline 201636 & ZOOLOGIA DE INVERTEBRADOS III & 3 & 34 & 2 & 19 & \\
\hline 201687 & GENETICA CLASSICA E CITOGENETICA & 4 & 68 & 4 & 20 & \\
\hline 901481 & POLITICAS E NORMAS DA EDUCACAO BASICA & 4 & 68 & 4 & 21 & \\
\hline 201635 & BOTANICA DE CRIPTOGAMAS & 4 & 68 & 4 & 22 & \\
\hline 201688 & METODOLOGIAS DE ENSINO DE CIENCIAS E BIOLOGIA & 4 & 68 & 4 & 23 & \\
\hline 201519 & ZOOLOGIA DE VERTEBRADOS & 4 & 68 & 4 & 24 & \\
\hline 201505 & ECOLOGIA DE POPULACOES E COMUNIDADES & 5 & 68 & 4 & 25 & \\
\hline 201632 & SISTEMATICA E EVOLUCAO BIOLOGICA & 5 & 68 & 4 & 26 & \\
\hline 405500 & FISIOLOGIA HUMANA & 5 & 68 & 4 & 27 & \\
\hline 901191 & EDUCACAO INCLUSIVA & 5 & 68 & 4 & 28 & \\
\hline 201521 & BOTANICA DE FANEROGAMAS & 5 & 68 & 4 & 29 & \\
\hline 201513 & ESTAGIO CURRICULAR SUPERVISIONADO EM BIOLOGIA I & 5 & 68 & 4 & 30 & \\
\hline 201656 & GENETICA DE POPULACOES E EVOLUCAO & 6 & 68 & 4 & 31 & \\
\hline 201534 & BIOLOGIA MOLECULAR BASICA & 6 & 68 & 4 & 32 & \\
\hline 201520 & MICROBIOLOGIA E IMUNOLOGIA & 6 & 68 & 4 & 33 & \\
\hline 901038 & PROJETOS INTERDISCIPLINARES & 6 & 68 & 4 & 34 & \\
\hline 101643 & LIBRAS & 6 & 68 & 4 & 35 & \\
\hline 201518 & ESTAGIO CURRICULAR SUPERVISIONADO EM BIOLOGIA II & 6 & 68 & 4 & 36 & \\
\hline 201524 & EMBRIOLOGIA E ANATOMIA COMPARADA & 7 & 68 & 4 & 37 & \\
\hline 201522 & ESTAGIO CURRICULAR SUPERVISIONADO EM BIOLOGIA III & 7 & 136 & 8 & 38 & \\
\hline 201689 & GEOLOGIA HISTORICA E PALEONTOLOGIA & 7 & 68 & 4 & 39 & \\
\hline 201690 & BIOLOGIA DE CAMPO & 7 & 34 & 2 & 40 & \\
\hline 990102 & SOCIEDADE E CONTEMPORANEIDADE & 7 & 68 & 4 & 41 & \\
\hline 201523 & BIOGEOGRAFIA HISTORICO - ECOLOGICA & 8 & 68 & 4 & 42 & \\
\hline 990100 & CULTURA RELIGIOSA & 8 & 68 & 4 & 43 & \\
\hline 201691 & ESTAGIO CURRICULAR SUPERVISIONADO EM EDUCACAO AMBIENTAL & 8 & 68 & 4 & 44 & \\
\hline 201526 & ESTAGIO CURRICULAR SUPERVISIONADO EM BIOLOGIA IV & 8 & 136 & 8 & 45 & \\
\hline
\end{tabular}

